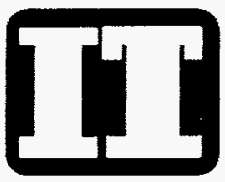

\title{
Summary of Micrographic Analysis of Fracture Coating Phases on Drill Cores from Pahute Mesa, Nevada Test Site
}

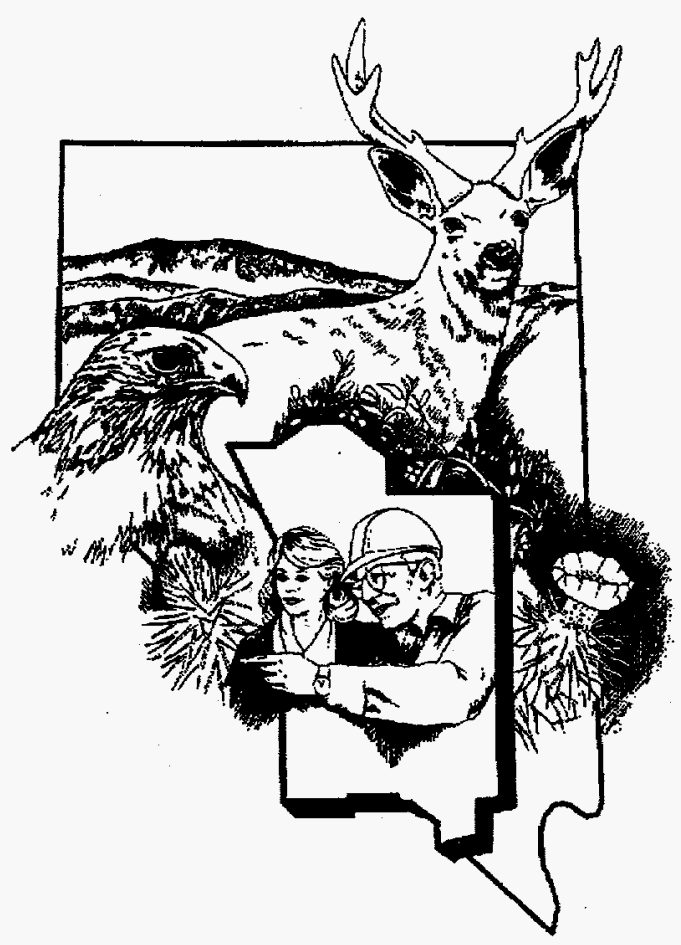

PECENG

DEC 21 १398

OSTI

Revision No.: 1

December 1998

DSTRIBUTION OF THIS DOCUMENT IS UNLMATED 
Available to the public from -

U.S. Department of Commerce

National Technical Information Service

5285 Port Royal Rciad

Springfield, VA 22161

(703) $487-4650$

Available electronically at http://www.doe.gov/bridge. Available to U.S. Department of Energy and its contractors in paper from -

U.S. Department of Energy

Office of Scientific and Technical Information

P.O. Box 62

Oak Ridge, TN 37831-0062

(423) 576-8401 


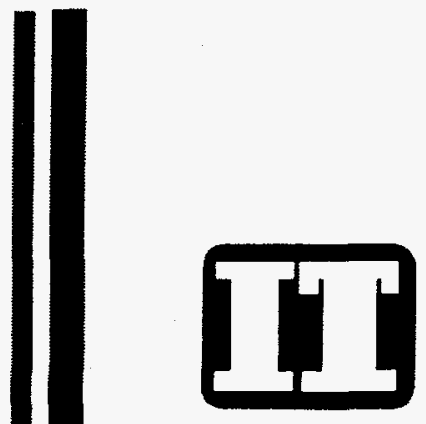

\section{SUMMARY OF MICROGRAPHIC}

ANALYSIS OF FRACTURE COATING

PHASES ON DRILL CORES FROM

PAHUTE MESA, NEVADA TEST SITE

Revision No.: 1

December 1998

IT CORPORATION

2621 Losee Road

Building B-1, Suite 3050-01

North Las Vegas, Nevada 89030

Prepared for U.S. Department of Energy. Nevada Operations Office under contract No. DE-AC08-97NV13052 


\section{DISCLAIMIER}

This report was prepared as an account of work sponsored by an agency of the United States Government. Neither the United States Government nor any agency thereof, nor any of their employees, makes any warranty, express or implied, or assumes any legal liability or responsibility for the accuracy, completeress, or usefulness of any information, apparatus, product, or process disclosed, or represents that its use would not infringe privately owned rights. Referesce berein to any speciñc commercial product, process, or service by trade name. trademark, manufac. turet, or otherwise does not necessarily constitute or imply its endorsement. recommendation. or favoring by the United States Governmeat or any ageacy thereof. The views and opinions of authors expressed herein do not aecessarily state or reflect those of the. United States Government or any agency thereof. 


\section{DISCLAIMER}

Portions of this document may be illegible in electronic image products. Images are produced from the best available original document. 


\section{SUMMARY OF MICROGRAPHIC ANALYSIS OF FRACTURE COATING PHASES ON DRILL CORES FROM PAHUTE MESA, NEVADA TEST SITE}
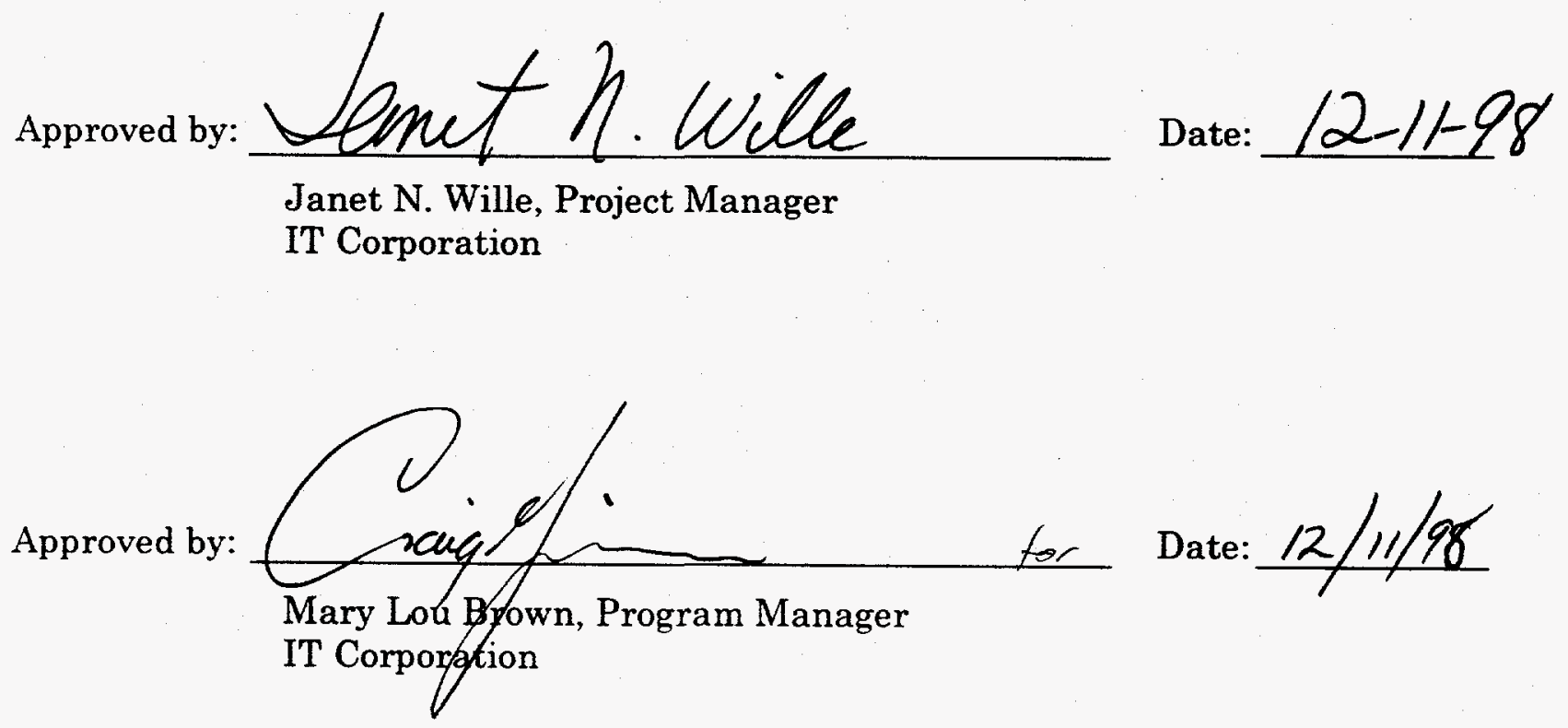
List of Figures $\ldots \ldots \ldots \ldots \ldots \ldots \ldots \ldots \ldots \ldots \ldots \ldots \ldots \ldots \ldots \ldots \ldots \ldots \ldots \ldots \ldots \ldots \ldots$

List of Tables $\ldots \ldots \ldots \ldots \ldots \ldots \ldots \ldots \ldots \ldots \ldots \ldots \ldots \ldots \ldots \ldots \ldots \ldots \ldots \ldots \ldots$

List of Acronyms and Abbreviations $\ldots \ldots \ldots \ldots \ldots \ldots \ldots \ldots \ldots \ldots \ldots \ldots \ldots \ldots \ldots \ldots$

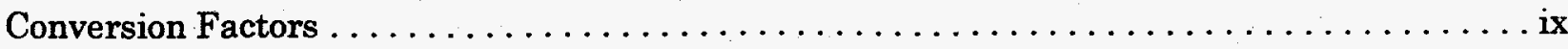

Executive Summary $\ldots \ldots \ldots \ldots \ldots \ldots \ldots \ldots \ldots \ldots \ldots \ldots \ldots \ldots \ldots \ldots \ldots \ldots \ldots \ldots$

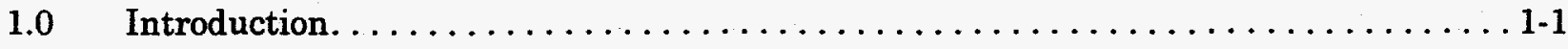

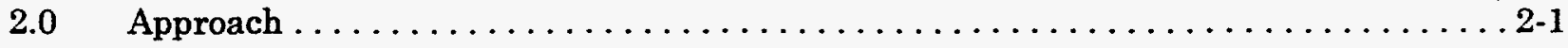

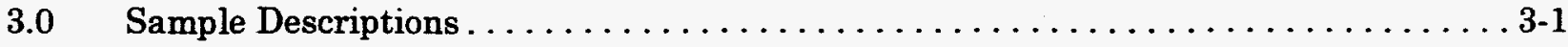

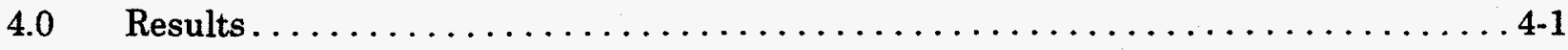

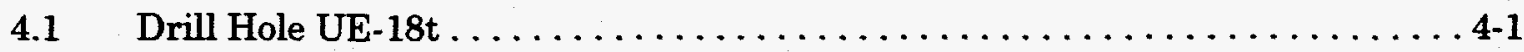

4.1.1 Sample from 1,378 Feet. . . . . . . . . . . . . . . . . . 4-1

4.1.2 Sample from $1,390.5$ Feet $\ldots \ldots \ldots \ldots \ldots \ldots \ldots \ldots \ldots \ldots \ldots \ldots$

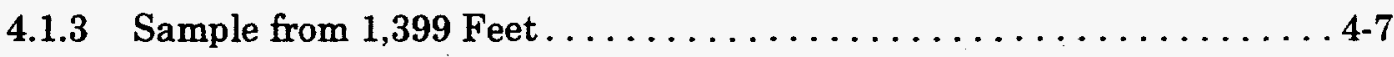

4.1.4 Sample from 2,002 Feet $\ldots \ldots \ldots \ldots \ldots \ldots \ldots \ldots \ldots \ldots \ldots \ldots \ldots$

4.1.5 Sample from 2,020 Feet . . . . . . . . . . . . . . . .

4.1.6 Sample from 2,583 Feet . . . . . . . . . . . . $\ldots \ldots \ldots \ldots 40$

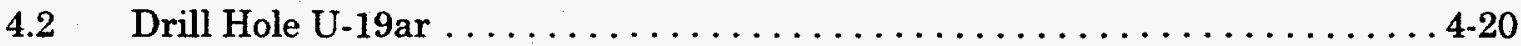

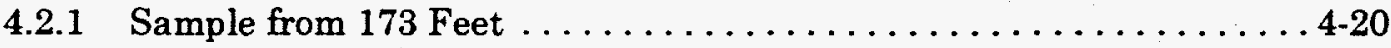

4.2 .2 Sample from 1,560 Feet $\ldots \ldots \ldots \ldots \ldots \ldots \ldots \ldots \ldots \ldots \ldots$ 4-22

4.3 Drill Hole UE-20f . . . . . . . . . . . . . . . . .

4.3.1 Sample from 8,668 Feet $\ldots \ldots \ldots \ldots \ldots \ldots \ldots \ldots \ldots \ldots \ldots \ldots \ldots 4-22$

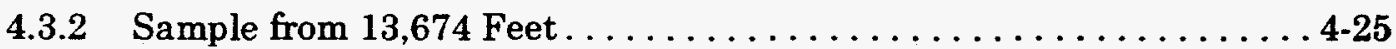

4.4 Drill Hole U-20as . . . . . . . . . . . . . . . . . . . . . 4 .25

4.4.1 Sample from 290 to 330 Feet. . . . . . . . . . . . . . 4 41

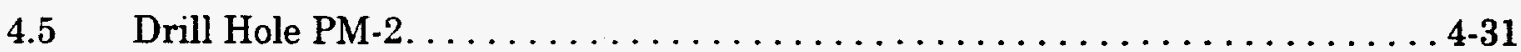

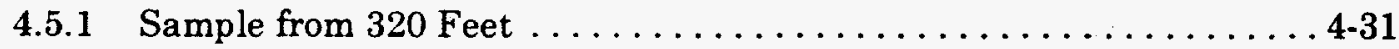

4.5.2 Sample from 4,180 Feet . . . . . . . . . . . . $\ldots \ldots \ldots \ldots \ldots$

4.5.3 Sample from 5,893 Feet $\ldots \ldots \ldots \ldots \ldots \ldots \ldots \ldots \ldots \ldots \ldots \ldots .4 \ldots \ldots \ldots$

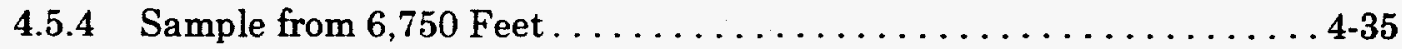

4.5.5 Sample from 8,050 Feet . . . . . . . . . . $\ldots \ldots \ldots \ldots \ldots \ldots$

4.5.6 Sample from 8,403 Feet . . . . . . . . . . . . . . . . . . 4-37 
4.6 Drill Hole PM-3. . . . . . . . . . . . . . . $\ldots \ldots \ldots \ldots \ldots \ldots \ldots$

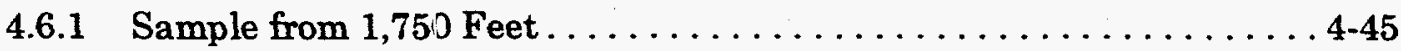

4.6.2 Sample from 1,790 to 1,810 Feet. . . . . . . . . . . . . . $\ldots \ldots$

4.6.3 Sample from 2,860 to 2,870 Feet. . . . . . . . . . . . . . . $4-45$

5.0 Conclusions . . . . . . . . . .

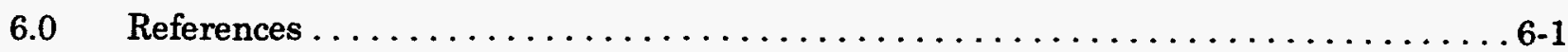

Appendix A - HRTEM Study of Coating Materials of Fe-Mn Oxides and Clays 
3-1 Pahute Mesa Area, Showing Drill Holes from which Archived Materials were Sampled....................... 3-2

4-1 SEM Image Showing Bladed Calcite from UE-18t (1,378 foot depth) . . . . . . . 4-2

4-2 SEM Image Showing Heulandite (h), Opal (o), and Smectite (s)

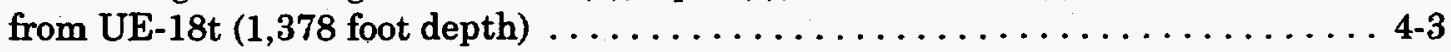

4-3 SEM Image Showing Delicate Smectite Web Structure from UE-18t (1,378 foot depth) $\ldots \ldots \ldots \ldots \ldots \ldots \ldots \ldots \ldots \ldots \ldots \ldots \ldots, 4-4$

4.4 Electron Microprobe (BSE) Image of Thin Section from UE-18t (1,378 foot depth) Showing Potassium Feldspar ( $f$ ), Analcime (a), Smectite Clay (s), and Calcite $(\mathrm{Cc}) \ldots \ldots \ldots \ldots \ldots \ldots \ldots \ldots \ldots \ldots$

4-5 SEM Image Showing Platy Apatite Crystals from

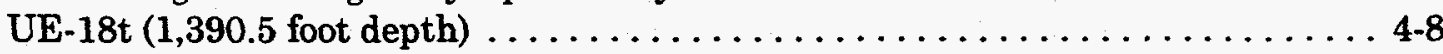

4-6 SEM Image Showing Fine-Grained Calcite Rhombs with Opaline Silica and Smectite from UE-18t (1,399 foot depth) . . . . . . . . . 4-9

4-7 SEM Image Showing Coarse Crystalline Analcime with Opaline Silica from UE-18t (1,399 foot depth) $\ldots \ldots \ldots \ldots \ldots \ldots \ldots \ldots \ldots, 4-10$

4-8 SEM Image Showing Corroded Analcime Crystals with Infilling by Opaline Silica and Calcite Rhombs from UE-18t (1,399 foot depth)

4-9 BSE Image of UE-18t (1,399 foot depth) Showing Apatite (ap) with Eroded Analcime (a). . . . . . . . . . . . . . . . . . . .

4-10 SEM Image Showing Eroded Calcite (Cc) with Local Smectite (s) Overgrowths from UE-18t (2,002 foot depth) (Fracture A)

4-11 BSE Image of UE-18t (2,002 foot depth) (Fracture A) Showing Eroded Calcite (Cc), Quartz (q), Feldspar (f), and Iron Oxide ( $\mathrm{Fe}$ ).

4-12 SEM Image Showing Pitted and Eroded Calcite (Cc) Adjacent to Mixed Hematite and Smectite from UE-18t (2,002 foot depth) (Fracture B).

4-13 SEM Image Showing Smectite (s) Web Between Eroded Calcite (Cc) and Hematite (h) from UE-18t (2,002 foot depth) (Fracture B)

4-14 BSE Image of UE-18t (2,002 foot depth) (Fracture B) Showing Calcite $(\mathrm{Cc})$ and Quartz $(\mathrm{q})$ with Iron Oxide $(\mathrm{Fe})$ Coating on Fracture 4-18

4-15 Electron Microprobe (BSE) Image of Thin Section (2,020 foot depth) from UE-18t Showing Calcite (Cc), Kaolinite (k), Quartz (q), Potassium Feldspar ( $f$ ), Ilmenite (il), and Biotite (b) 
4-16 SEM Image Showing Ragged Illite Plates from UE-18t

(2,583 foot depth)

4-17 SEM Image Showing Thin Veil of Smectite Clay on Glass from

U-19ar (173 foot depth).

4-18 SEM Image Showing Incipient Smectite Growth on

Glassy Lapilli Fragment from U-19ar (1,560 foot depth) .

4-19 SEM Image Showing Very Fine-Grained Nature of Mixed

Fracture Coating Material Comprised of Hematite, Quartz, Illite,

Manganese Oxides, and Alkali Feldspars from UE-20f

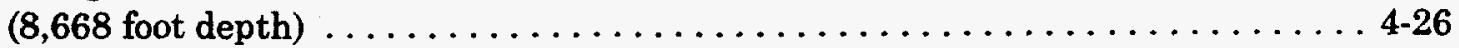

4-20 SEM Image Showing a Shallow Crack and the Layering in the

Fracture Coating Material from UE-20f (8,668 foot depth) . . . . . . . . . 4-27

4-21 SEM Image Showing Blocky, Uneroded Calcite (Cc) with

Overgrowth of Illite/Smectite (i/s) Mixed with Goethite from

UE-20f (13,674 foot depth) .

4-22 SEM Image Showing Euhedral to Subhedral Pyrite Cubes in Vein

Matrix of Massive to Sugary G,uartz from UE-120f (13,674 foot depth)

4-23 BSE Image of UE-20f (13,674 foot depth) Showing Calcite (Cc)

with an Eroded Iron-Rich Rim, and Quartz (q) on Fracture Surface,

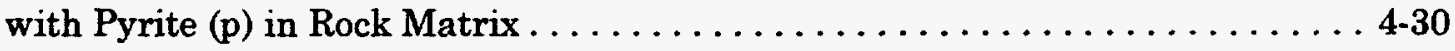

4-24 SEM Image Showing Botryoidal Opaline Silica (with later opaline

overgrowths) and Eroded Calcite from PM-2 (320 foot depth) . . . . . . . 4-32

4-25 BSE Image of PM-2 (320 foot depth) Showing Growth Bands

in Botryoidal Opaline Silica with Calcite $(\mathrm{Cc}) \ldots \ldots \ldots \ldots \ldots \ldots \ldots \ldots . \ldots \ldots$

4-26 Electron Microprobe Elemental Map for Silica in PM-2 (320 foot depth) . . . . 4-34

4-27 SEM Image Showing Barite Coating Partially Open Fracture

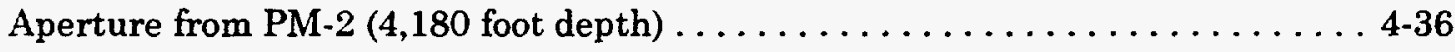

4-28 SEM Image Showing Eroded Calcite on Fracture from PM-2

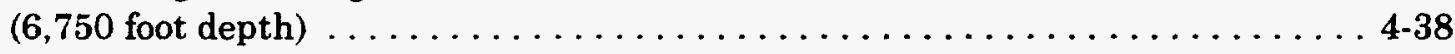

4-29 SEM Image Showing Chlorite on Pitted Calcite from PM-2

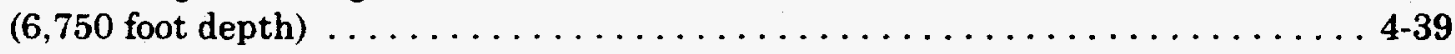

4-30 BSE Image of PM-2 (8,050 foot depth) Showing Calcite (Cc), Quartz (q), Chlorite (c), Epidote (e), Potassium Feldspar (f), and

Pyrite $(\mathrm{p})$ Alteration $\ldots \ldots \ldots \ldots \ldots \ldots \ldots \ldots \ldots \ldots \ldots \ldots \ldots \ldots \ldots \ldots \ldots \ldots \ldots$

4-31 SEM Image Showing Eroded Calcite (Cc) and Quartz (q) with

Mixed Illite/Smectite Mat (i/s) from PM-2 (8,403 foot depth). . . . . . . . 4-41 
Number

Title

Page

4-32 SEM Image Showing Close-Up View of Eroded Quartz Crystals with Coating of Mixed Illite/Smectite from PM-2 (8,403 foot depth). .

4-33 SEM Image Showing Locally Well Developed Mixed Illite/Smectite Clay Mat from PM-2 (8,403 foot depth)

4-34 SEM Image Showing Coarse, Blocky, Eroded and Etched Carbonate with Spotty Local Growths of Illite/Smectite from PM-2

$(8,403$ foot depth)

4-35 BSE Image of PM-2 (8,403 foot depth) Showing Calcite (Cc), Quartz (q), and Pyrite (p) 
Number

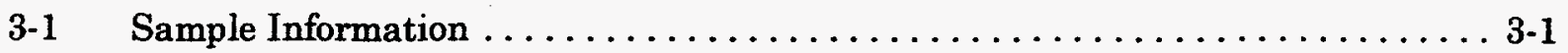

3-2 Drill Hole Identification, Depths to Groundwater, Sampling Intervals, Lithostratigraphic Description, and Hydrostratigraphic Descriptions for Fracture Coating and Calcite Samples Collected from Pahute Mesa ....... 3-3

4-1 Electron Microprobe Results (in weight percent oxide) for Point Analyses of Selected Specific Phases in Drill Core Samples from Pahute Mesa

5-1 Summary of Fracture Coating Phase Distribution as a Function of Hydrostratigraphy 


\begin{tabular}{|c|c|}
\hline $\mathrm{Al}$ & Aluminum \\
\hline $\mathrm{Ba}$ & Barium \\
\hline BSE & Backscattered Electron \\
\hline $\mathrm{C}$ & Carbon \\
\hline $\mathrm{Ca}$ & Calcium \\
\hline $\mathrm{Cl}$ & Chlorine \\
\hline DOE & U.S. Department of Energy \\
\hline DRI & Desert Research Institute \\
\hline EDS & Energy dispersive spectroscopy \\
\hline $\mathbf{F}$ & Fluorine \\
\hline $\mathrm{Fe}$ & Iron \\
\hline $\mathrm{H}$ & Hydrogen \\
\hline HRTEM & High-resolution transmission electron microscope \\
\hline $\mathrm{IT}$ & IT Corporation \\
\hline $\mathrm{K}$ & Potassium \\
\hline $\mathrm{Li}$ & Lithium \\
\hline LLNL & Lawrence Livermore National Laboratory \\
\hline $\mathrm{Mg}$ & Magnesium \\
\hline $\mathrm{Mn}$ & Manganese \\
\hline $\mathrm{Na}$ & Sodium \\
\hline NTS & Nevada Test Site \\
\hline $\mathrm{O}$ & Oxygen \\
\hline $\mathbf{P}$ & Phosphorus \\
\hline S & Sulfur \\
\hline SAED & Sleeted area electron diffraction \\
\hline SEM & Scanning electron microscope \\
\hline $\mathrm{Si}$ & Silicon \\
\hline $\mathrm{Sr}$ & Strontium \\
\hline $\mathrm{Ti}$ & Titanium \\
\hline USGS & U.S. Geological Survey \\
\hline
\end{tabular}




\section{List of Acronyms and Abbreviations (Continued)}

WDS Wavelength dispersive spectroscopy

ZAF Atomic number-absorbtion-fluoresence 
Multiply

foot $(\mathrm{ft})$

inches (in.)

Micron

inch

inch $^{2}$
By

$3.048 \times 10^{-1}$

$2.54 \times 10^{0}$

$1 \times 10^{-6}$

$2.54 \times 10^{+1}$

$6.54 \times 10^{2}$
To Obtain

meter (m)

centimeter $(\mathrm{cm})$

meter (m)

millimeter

millimeter squared 


\section{Executive Summary}

Fracture coating mineral phases on 14 archived core samples from three drill holes in the Pahute Mesa area were analyzed using micrographic techniques. Six additional samples (cuttings and percussion gun sidewall cores) of non-fractured, calcite-bearing materials from three other drill holes on Pahute Mesa were collected primarily for isotopic evaluation. Three of the principal volcanic aquifers hosting groundwater flow are represented by the samples collected. Fracture coating phases within the Timber Mountain Aquifer system are characterized by calcite + mixed illite/smectite + opaline silica in the unsaturated zone and by calcite + mixed illite/smectite + quart + feldspars + zeolites $+\mathrm{Fe}-$ and $\mathrm{Mn}$-oxyhydroxides in the saturated zone. A single sample from the saturated portion of the Belted Range Aquifer is characterized by intense fracturing and the predominance of $\mathrm{Fe}$ - and $\mathrm{Mn}$-oxyhydroxides with subordinate calcite + quartz + feldspars + mixed illite/smectite. This suggests the presence of a significant transmissive hydrogeologic feature or stratigraphic interval. The predominance of secondary oxide phases in this sample also has important connotations for the potential adsorption of dissolved solutes. Fracture coating phases within the Basal Aquifer are characterized by phases more indicative of an active hydrothermal environment (such as quartz + pyrite + barite) rather than precipitation from a groundwater system. The distinct fracture coating phase assemblages in the three aquifer systems have the potential to impart a geochemical signature to resident groundwaters. This may result in isotopic exchange during water-rock interaction, adsorption of solutes by zeolites and/or Fe- and Mn-oxyhydroxides, or dissolution of relatively soluble phases such as sulfides, volcanic glass, and feldspars. Calcite textures in these samples indicate that carbonate dissolution and precipitation is widespread. The presence of multiple generations of calcite along with other carbonate minerals suggests that these aquifer systems are near equilibrium with respect to carbonate. These geochemical processes should be reflected in the water chemistry of Pahute Mesa groundwaters and will be evaluated as part of the Oasis Valley geochemical modeling conducted during FY 1999. 
This Page Intentionally Left Blank 


\section{Introduction}

The flow path between Pahute Mesa and the groundwater discharge area in Oasis Valley (approximately 18 miles to the southwest) is of concern due to the relatively short travel distance between a recharge area where underground nuclear testing has been conducted and the off-site water users. Groundwater flow and transport modeling by IT Corporation (IT) has shown rapid tritium transport in the volcanic rock aquifers along this flow path (DOE/NV, 1997). The resultant estimates of rapid transport were based on water level data, limited hydraulic conductivity data, estimates of groundwater discharge rates in Oasis Valley, assumed porosities, and estimated retardation rates. Many of these parameters are poorly constrained and may vary considerably. Sampling and analytical techniques are being applied as an independent means to determine transport rates by providing an understanding of the geochemical processes that control solute movement along the flow path. Collaborative geochemical investigations include participants from the U.S. Geological Survey (USGS), Desert Research Institute (DRI), IT, and Lawrence Livermore National Laboratory (LLNL). The intent of these investigations is to use geochemical and isotopic constraints to independently verify the Pahute Mesa - Oasis Valley numerical groundwater flow model, and to determine the age, related travel time, and solute attenuation characteristics for groundwater moving along this flow path.

As part of these geochemical investigations, this report summarizes the analysis of fracture coating mineral phases from drill core samples from the Pahute Mesa area of the Nevada Test Site (NTS). Archived samples were collected based on the presence of natural fractures and on the types and abundance of secondary mineral phases present on those fracture surfaces. Mineral phases present along fracture surfaces are significant because, through the process of water-rock interaction, they can either contribute (as a result of dissolution) or remove (as a result of precipitation or adsorption) constituents from solution. Particular attention was paid to secondary calcite occurrences because they represent a potential source of exchangeable carbon and can interact with groundwater resulting in a modified isotopic signature and apparent water age. A companion report by Rose et al. (1998) discusses the results of the stable isotope and radiocarbon analyses of the calcite from these samples. 
This Page Intentionally Left Blank 


\section{Approach}

Sample properties that were evaluated include:

- Sample mineralogy, specifically secondary phases on fracture surfaces

- The chemical composition of selected mineral phases that are assumed to be relatively soluble (e.g., volcanic glass or feldspars) or phases (such as zeolites or iron and manganese oxyhydroxides) that are assumed to be effective substrates for the adsorption of dissolved solutes

The sample analysis activities were performed using a combination of optical petrographic, scanning electron micrographic, electron microprobe, and high-resolution transmission electron micrographic techniques. The scanning electron microscope (SEM) and electron microprobe analyses were conducted using the U.S. Geological Survey Microbeam Laboratory, at the Denver Federal Center in Lakewood, Colorado, with the assistance of Greg Meeker.

The SEM used is a JEOL 5800LV coupled with an Oxford ISIS energy dispersive spectroscopy(EDS) system. Typical accelerator voltage used on the SEM was 20 kilovolts. Due to the size constraints of the SEM sample chamber, portions (up to $3 \times 3$ centimeters) of the natural exposed open fracture surfaces were separated from the main sample and gold-coated for textural and mineralogical evaluation in the SEM.

The electron microprobe is a JEOL 8900. Microprobe analyses were corrected using wavelength dispersive spectroscopy (WDS) and ZAF (atomic number - absorption - fluorescence) oxide correction procedures. Backscattered electron (BSE) images and quantitative, large-scale digital $x$-ray images (or elemental maps) were collected using wavelength spectrometers (for $\mathrm{Si}$ ) by rastering the stage under a stationary electron probe. A single elemental map was obtained from one sample of an area of 4 square millimeters, using 1,000 by 1,000 pixels and a pixel size of 2 microns.

The high-resolution transmission electron microscope (HRTEM) analyses were conducted under contract by Huifang $\mathrm{Xu}$, manager of the Transmission Electron Microscopy Laboratory, at the University of New Mexico in Albuquerque, New Mexico. Four separate sub-samples were sent to the University of New Mexico for the preparation of 
ion-milled thin sections and powder samples as summarized in the report by $\mathrm{Xu}$ (1998), which is attached as Appendix $\mathrm{A}$.

All HRTEM analyses were conducted using a JEOL 2010 HRTEM and associated Link ISIS EDS system with an ultra-thin window for the detector. HRTEM parameters are specified in Appendix A. 


\section{Sample Descriptions}

Twenty sub-samples were collected from drill core, cuttings, and percussion gun sidewall core archived at the USGS Core Library in Mercury, Nevada. A preference was given to core samples, due to the high quality preservation of mineral phase relationships on fracture surfaces. However, cuttings and percussion gun sidewall cores were also collected for the isotopic analysis of calcite based on information contained in Warren et al. (1998). The locations of the six drill holes that were sampled are shown in Figure 3-1. Sampling was conducted in April 1998, after sample selection and the sampling plan had been approved by the custodial agency for each drill hole of interest. Samples were collected from the drill holes and depth intervals shown in Table 3-1.

Table 3-1

Sample Information

\begin{tabular}{|c|c|c|}
\hline $\begin{array}{c}\text { Well Name } \\
\text { Custodial Agency }\end{array}$ & $\begin{array}{c}\text { Depth } \\
\text { (feet below } \\
\text { ground surface) }\end{array}$ & Sampie Type \\
\hline $\begin{array}{l}\text { UE-18t } \\
\text { Hydrology and Radionuclide } \\
\text { Migration Program }\end{array}$ & $\begin{array}{c}1,378 \\
1,390.5 \\
1,399 \\
2,002 \\
2,020 \\
2,583\end{array}$ & fractured drill core \\
\hline $\begin{array}{l}\text { U-19ar } \\
\text { Los Alamos National Laboratory }\end{array}$ & $\begin{array}{c}173 \\
1,560\end{array}$ & percussion gun sidewall core \\
\hline $\begin{array}{l}\text { U-20as } \\
\text { Lawrence Livermore National } \\
\text { Laboratory }\end{array}$ & 290 to 300 & drill cuttings from 10 -foot intervals \\
\hline $\begin{array}{l}\text { UE-20f } \\
\text { Lawrence Livermore National } \\
\text { Laboratory }\end{array}$ & $\begin{array}{c}8,668 \\
13,674\end{array}$ & fractured drill core \\
\hline $\begin{array}{l}\text { PM-2 } \\
\text { Hydrology and Radionuclide } \\
\text { Migration Program }\end{array}$ & $\begin{array}{c}320 \\
4,180 \\
5,893 \\
6,750 \\
8,050 \\
8,403\end{array}$ & fractured drill core \\
\hline $\begin{array}{l}\text { PM-3 } \\
\text { Hydrology and Radionuclide } \\
\text { Migration Program }\end{array}$ & $\begin{array}{c}1,750 \\
1,790 \text { to } 1,810 \\
2,860 \text { to } 2,870\end{array}$ & $\begin{array}{l}\text { percussion gun sidewall core } \\
\text { drill cuttings from } 10 \text {-foot intervals } \\
\text { drill cuttings from } 10 \text {-foot intervals }\end{array}$ \\
\hline
\end{tabular}




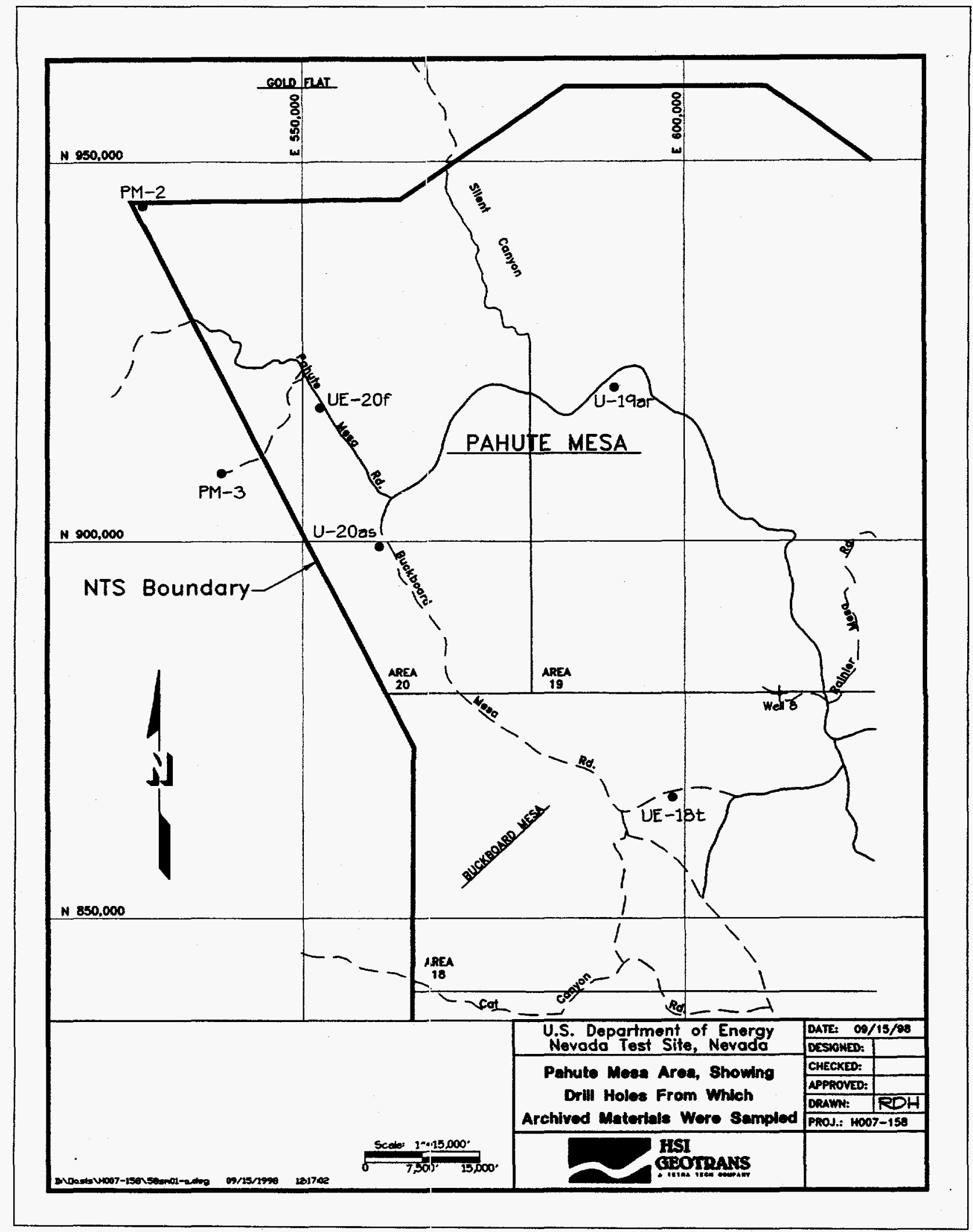

Figure 3-1

Pahute Mesa Area, Showing Drill Holes from which Archived Materials were Sampled 
Drill hole information including standing water level (from Laczniak et al., 1996), depth interval sampled, and lithostratigraphic (from drill logs on file at the USGS Core Library and from Warren et al., 1998) and hydrostratigraphic (from Prothro and Drellack, 1997) descriptions of sample intervals are summarized in Table 3-2. Additional data comes from a report summarizing a fracture analysis conducted on Pahute Mesa (Drellack et al., 1997), which includes drill holes UE-18t and UE-20f.

Table 3-2

Drill Hole Identification, Depths to Groundwater, Sampling Intervals, Lithostratigraphic Description, and Hydrostratigraphic Descriptions for Fracture Coating and Calcite Samples Collected from Pahute Mesa (Page 1 of 2)

\begin{tabular}{|c|c|c|c|c|}
\hline Drill Hole & $\begin{array}{c}\text { Standing Water } \\
\text { Level } \\
\text { (feet below } \\
\text { ground surface) }\end{array}$ & $\begin{array}{l}\text { Depth Intervals } \\
\text { Sampled } \\
\text { (feet below } \\
\text { ground surface) }\end{array}$ & $\begin{array}{l}\text { Lithostratigraphic } \\
\text { Unit }^{2}\end{array}$ & $\begin{array}{c}\text { Hydrostratigraphic } \\
\text { Unit }^{3}\end{array}$ \\
\hline \multirow{6}{*}{ UE-18t } & \multirow{6}{*}{916} & 1,378 & $\begin{array}{l}\text { Timber Mountain } \\
\text { Group } \\
\text { Ammonia Tanks Tuff }\end{array}$ & $\begin{array}{l}\text { Timber Mountain } \\
\text { Aquifer } \\
\text { vitric tuff aquifer }\end{array}$ \\
\hline & & $1,390.5$ & $\begin{array}{l}\text { Timber Mountain } \\
\text { Group } \\
\text { Ammonia Tanks Tuff }\end{array}$ & $\begin{array}{l}\text { Timber Mountain } \\
\text { Aquifer } \\
\text { vitric tuff aquifer }\end{array}$ \\
\hline & & 1,399 & $\begin{array}{l}\text { Timber Mountain } \\
\text { Group } \\
\text { Ammonia Tanks Tuff }\end{array}$ & $\begin{array}{l}\text { Timber Mountain } \\
\text { Aquifer } \\
\text { vitric tuff aquifer }\end{array}$ \\
\hline & & 2,002 & $\begin{array}{l}\text { Timber Mountain } \\
\text { Group } \\
\text { Rainier Mesa Tuff }\end{array}$ & $\begin{array}{l}\text { Timber Mountain } \\
\text { Aquifer } \\
\text { welded tuff aquifer }\end{array}$ \\
\hline & & 2,020 & $\begin{array}{l}\text { Timber Mountain } \\
\text { Group } \\
\text { Rainier Mesa Tuff }\end{array}$ & $\begin{array}{l}\text { Timber Mountain } \\
\text { Aquifer } \\
\text { welded tuff aquifer }\end{array}$ \\
\hline & & 2,583 & $\begin{array}{l}\text { Timber Mountain } \\
\text { Group } \\
\text { Rainier Mesa Tuff }\end{array}$ & $\begin{array}{l}\text { Timber Mountain } \\
\text { Aquifer } \\
\text { welded tuff aquifer }\end{array}$ \\
\hline \multirow{2}{*}{ U-19ar } & \multirow{2}{*}{2,119} & $\begin{array}{c}173 \\
\text { sidewall core }\end{array}$ & $\begin{array}{l}\text { Thirsty Canyon Group } \\
\text { Pahute Mesa Tuff }\end{array}$ & $\begin{array}{l}\text { Timber Mountain } \\
\text { Aquifer } \\
\text { vitric tuff aquifer }\end{array}$ \\
\hline & & $\begin{array}{c}1,560 \\
\text { sidewall core }\end{array}$ & $\begin{array}{l}\text { Timber Mountain } \\
\text { Group } \\
\text { Pool Member }\end{array}$ & $\begin{array}{l}\text { Timber Mountain } \\
\text { Aquifer } \\
\text { vitric tuff aquifer }\end{array}$ \\
\hline U-20as & 2,010 & $\begin{array}{l}290 \text { to } 330 \\
\text { cuttings }\end{array}$ & $\begin{array}{l}\text { Timber Mountain } \\
\text { Group } \\
\text { Ammonia Tanks Tuff }\end{array}$ & $\begin{array}{l}\text { Timber Mountain } \\
\text { Aquifer } \\
\text { vitric tuff aquifer }\end{array}$ \\
\hline \multirow{2}{*}{ UE-20f } & \multirow{2}{*}{1,954} & 8,668 & $\begin{array}{l}\text { Belted Range Group } \\
\text { Lava of Split Ridge }\end{array}$ & $\begin{array}{l}\text { Belted Range Aquifer } \\
\text { lava flow aquifer }\end{array}$ \\
\hline & & 13,674 & $\begin{array}{l}\text { Volcanics of Oak } \\
\text { Spring Butte }\end{array}$ & $\begin{array}{l}\text { Basal Aquifer } \\
\text { welded tuff aquifer }\end{array}$ \\
\hline
\end{tabular}


Table 3-2

Drill Hole Idıntification, Depths to Groundwater, Sampling Intervals, Lithostratigraphic Description, and Hydrostratigraphic Descriptions for Fracture Coating and Calcite Samples Collected from Pahute Mesa (Page 2 of 2)

\begin{tabular}{|c|c|c|c|c|}
\hline Drill Hole & $\begin{array}{c}\text { Standing Water } \\
\text { Level' } \\
\text { (feet below } \\
\text { ground surface) }\end{array}$ & $\begin{array}{c}\text { Depth Intervals } \\
\text { Sampled } \\
\text { (feet below } \\
\text { ground surface) }\end{array}$ & $\begin{array}{c}\text { Lithostratigraphic } \\
\text { Unit }^{2}\end{array}$ & $\begin{array}{c}\text { Hydrostratigraphic } \\
\text { Unit }^{3}\end{array}$ \\
\hline \multirow{6}{*}{ PM-2 } & \multirow{6}{*}{ B52 } & 320 & $\begin{array}{l}\text { Thirsty Canyon Group } \\
\text { Spearhead Tuff }\end{array}$ & $\begin{array}{l}\text { Timber Mountain } \\
\text { Aquifer } \\
\text { vitric tuff aquifer }\end{array}$ \\
\hline & & 4,180 & $\begin{array}{l}\text { Volcanics of Quartz } \\
\text { Mountain } \\
\text { Dacite of Mt. Helen }\end{array}$ & $\begin{array}{l}\text { Basal Aquifer } \\
\text { lava flow aquifer }\end{array}$ \\
\hline & & 5,893 & $\begin{array}{l}\text { Volcanics of Quartz } \\
\text { Mountain } \\
\text { Rhyodacite to Dacite } \\
\text { Flows }\end{array}$ & $\begin{array}{l}\text { Basal Aquifer } \\
\text { lava flow aquifer }\end{array}$ \\
\hline & & 6,750 & $\begin{array}{l}\text { Volcanics of Quartz } \\
\text { Mountain } \\
\text { Rhyodacite to Dacite } \\
\text { Flows }\end{array}$ & $\begin{array}{l}\text { Basal Aquifer } \\
\text { lava flow aquifer }\end{array}$ \\
\hline & & 8,050 & $\begin{array}{l}\text { Volcanics of Quartz } \\
\text { Mountain } \\
\text { Rhyodacite to Dacite } \\
\text { Flows }\end{array}$ & $\begin{array}{l}\text { Basal Aquifer } \\
\text { lava flow aquifer }\end{array}$ \\
\hline & & 8,403 & $\begin{array}{l}\text { Altered and brecciated } \\
\text { Tertiary granodiorite }\end{array}$ & Basal Aquifer \\
\hline \multirow{3}{*}{ PM-3 } & \multirow{3}{*}{1,457} & $\begin{array}{c}1,750 \\
\text { sidewall core }\end{array}$ & Basalt of U-19ac & $\begin{array}{l}\text { Upper Paintbrush } \\
\text { Confining Unit }\end{array}$ \\
\hline & & $\begin{array}{l}1,790 \text { to } 1,810 \\
\text { cuttings }\end{array}$ & Basalt of U-19ac & $\begin{array}{l}\text { Upper Paintbrush } \\
\text { Confining Unit }\end{array}$ \\
\hline & & $\begin{array}{c}2,860 \text { to } 2,870 \\
\text { cuttings }\end{array}$ & $\begin{array}{l}\text { Basaltic lavas of } \\
\text { UE-19e }\end{array}$ & $\begin{array}{l}\text { Calico Hills Confining } \\
\text { Unit }\end{array}$ \\
\hline
\end{tabular}

'Laczniak et al., 1996

2Warren et al., 1998

${ }^{3}$ Prothro and Drellack, 1997 


\section{Results}

\subsection{Drill Hole UE-18t}

Exploratory hole UE-18t was drilled in 1978 immediately southeast of Pahute Mesa in the northeastern portion of the Timber Mountain caldera moat area. This hole was drilled to evaluate the suitability of the Timber Mountain caldera moat for underground nuclear testing (Byers et al., 1981). The drill hole has a total depth of 2,600 feet and was continuously cored over the interval from 120.1 to 2,600 feet. The entire drill hole is completed within the Timber Mountain Aquifer, comprised of both vitric tuff aquifer consisting of the Ammonia Tanks Member of the Timber Mountain Group, and welded tuff aquifer consisting of the Rainier Mesa Member of the Timber Mountain Group (Drellack et al., 1997). Six samples representing fractured units of both of these hydrostratigraphic intervals were collected and analyzed.

\subsubsection{Sample from 1,378 Feet}

This is a sample of pumice lapilli tuff of the Ammonia Tanks Member of the Timber Mountain Group, comprising the vitric tuff aquifer of the Timber Mountain Aquifer. In this interval, the tuff is transected by an open vertical fracture which has an aperture of up to 2 millimeters. Oxide pseudomorphs (after pyrite?) seen in hand specimen suggest some degree of hydrothermal alteration. The fracture surface in this interval is largely covered with loosely attached, thin, platy calcite crystals (Figure 4-1). These crystals occur in aggregates up to 3 millimeters in thickness and up to 100 square millimeters in areal extent. Where not coated with calcite, the fracture surface is typically coated with a mixture of smectite [having a general formula of $\mathrm{AM}_{2}(\mathrm{Si}, \mathrm{Al})_{4} \mathrm{O}_{10} \cdot \mathrm{H}_{2} \mathrm{O}$, where $\mathrm{A}=\mathrm{Na}, \mathrm{Ca}, \mathrm{K}$, or $\mathrm{Li}$ and $\mathrm{M}=\mathrm{Al}, \mathrm{Mg}$, or $\mathrm{Fe}]$, heulandite $\left[\left(\mathrm{Ca}, \mathrm{Na}_{2}, \mathrm{~K}_{2}\right)_{4}\left(\mathrm{Al}_{8} \mathrm{Si}_{28} \mathrm{O}_{72}\right) \cdot 24 \mathrm{H}_{2} \mathrm{O}\right]$, and opaline silica $\left[\mathrm{SiO}_{2} \cdot n \mathrm{H}_{2} \mathrm{O}\right]$ as shown in Figure 4-2, or coated with a locally pervasive, web-like coating of smectite (Figure 4-3). Mineral compositions listed are idealized and taken from Deer et al. (1992).

An electron microprobe backscattered electron (BSE) image of a thin section through the fracture surface (Figure 4-4) shows the fracture coating phase relationships. As shown, alkali feldspar appears to be the earliest fracture coating phase and is intimately associated with potassium feldspar and analcime. The analcime is coated by smectite 


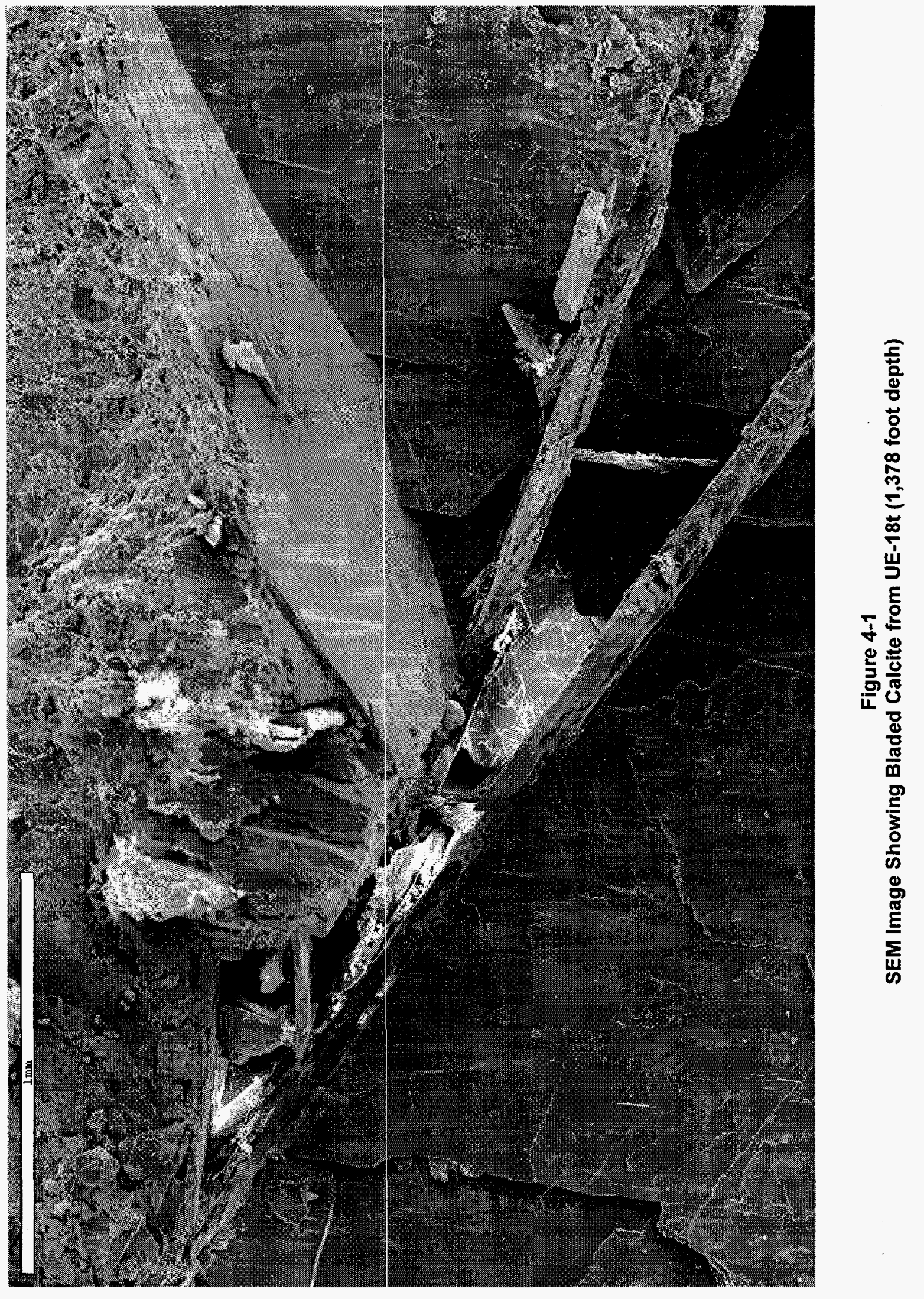




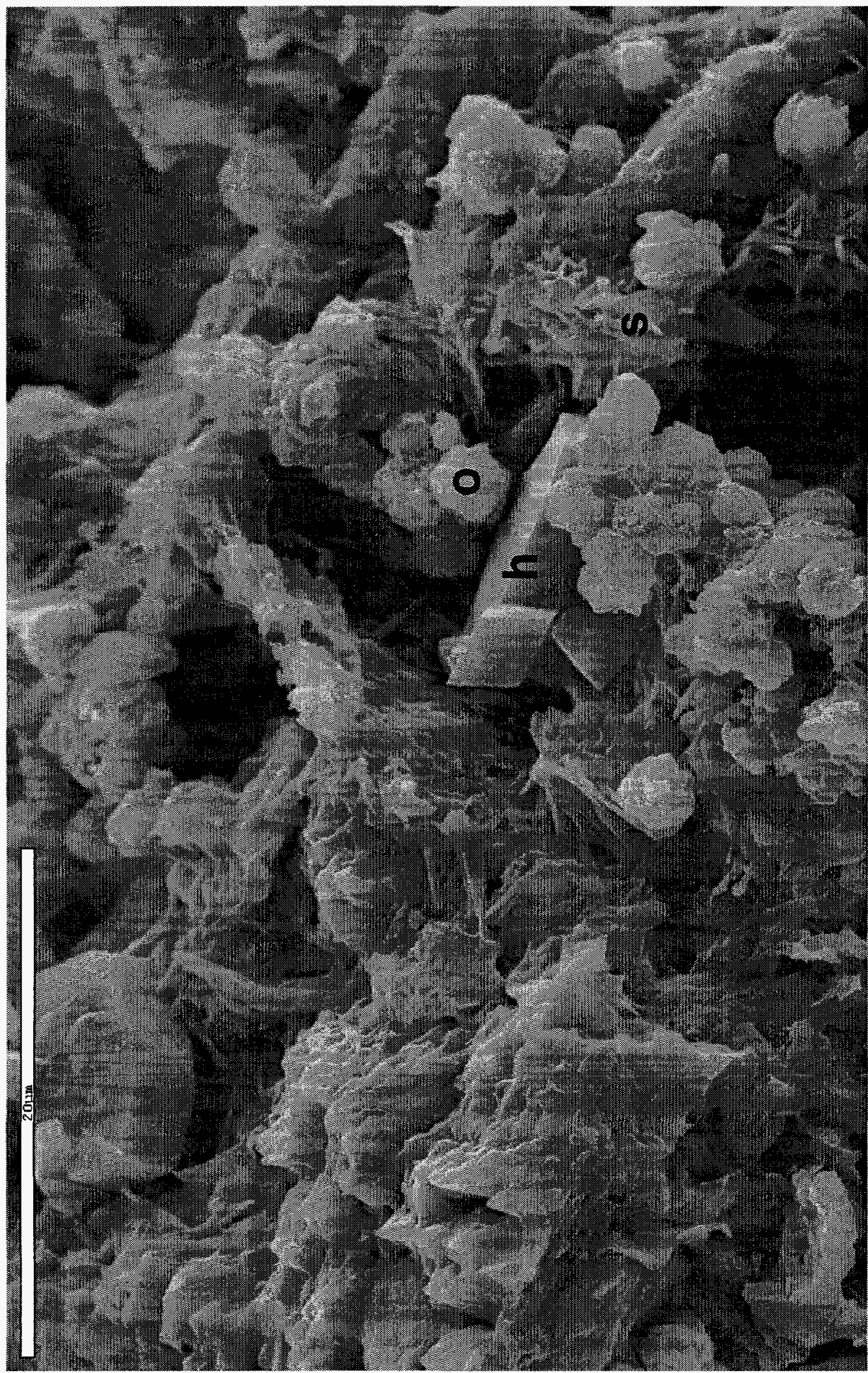

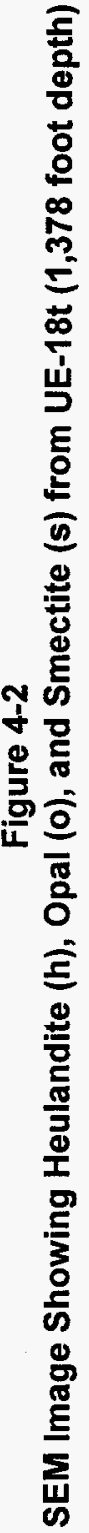




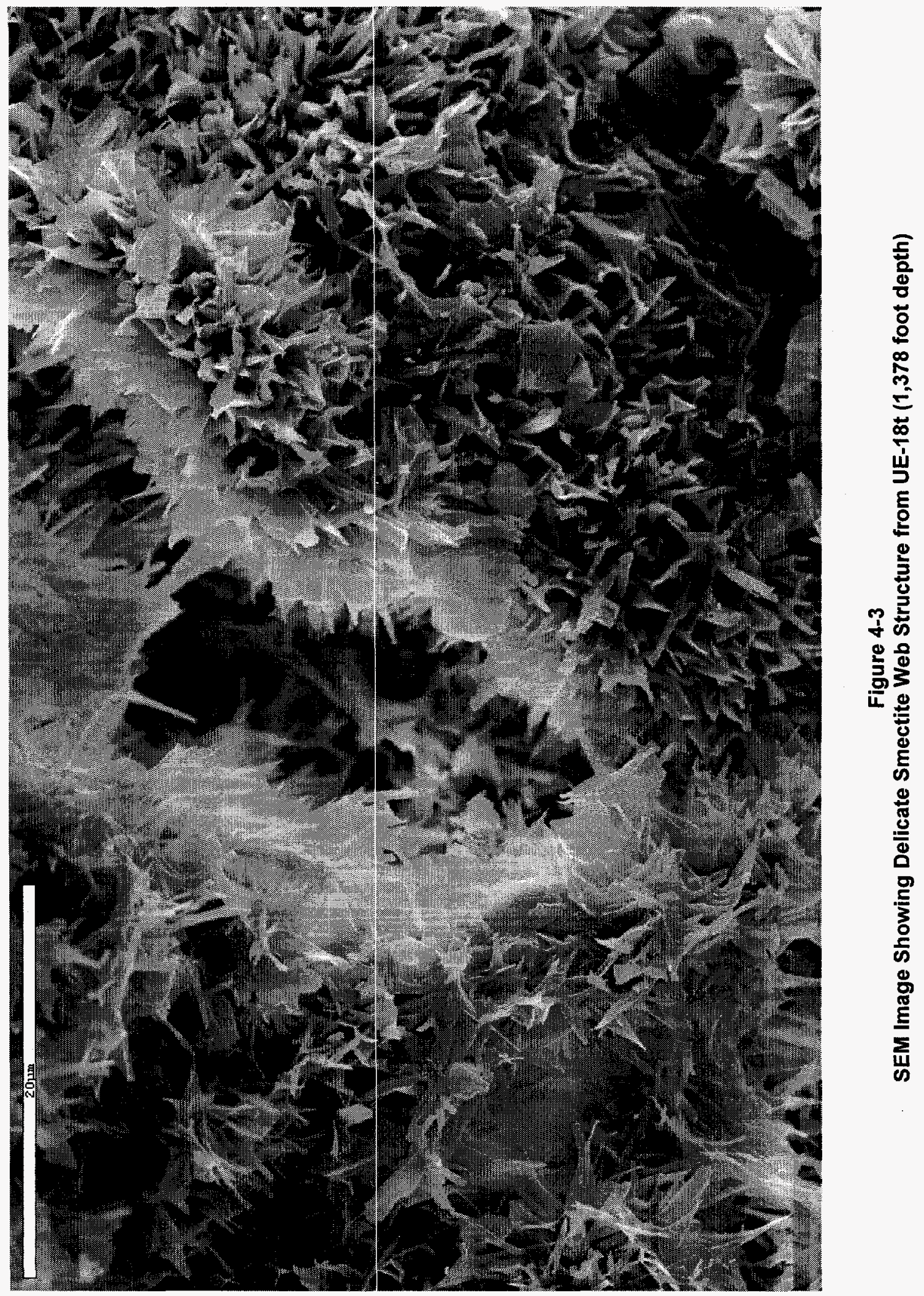




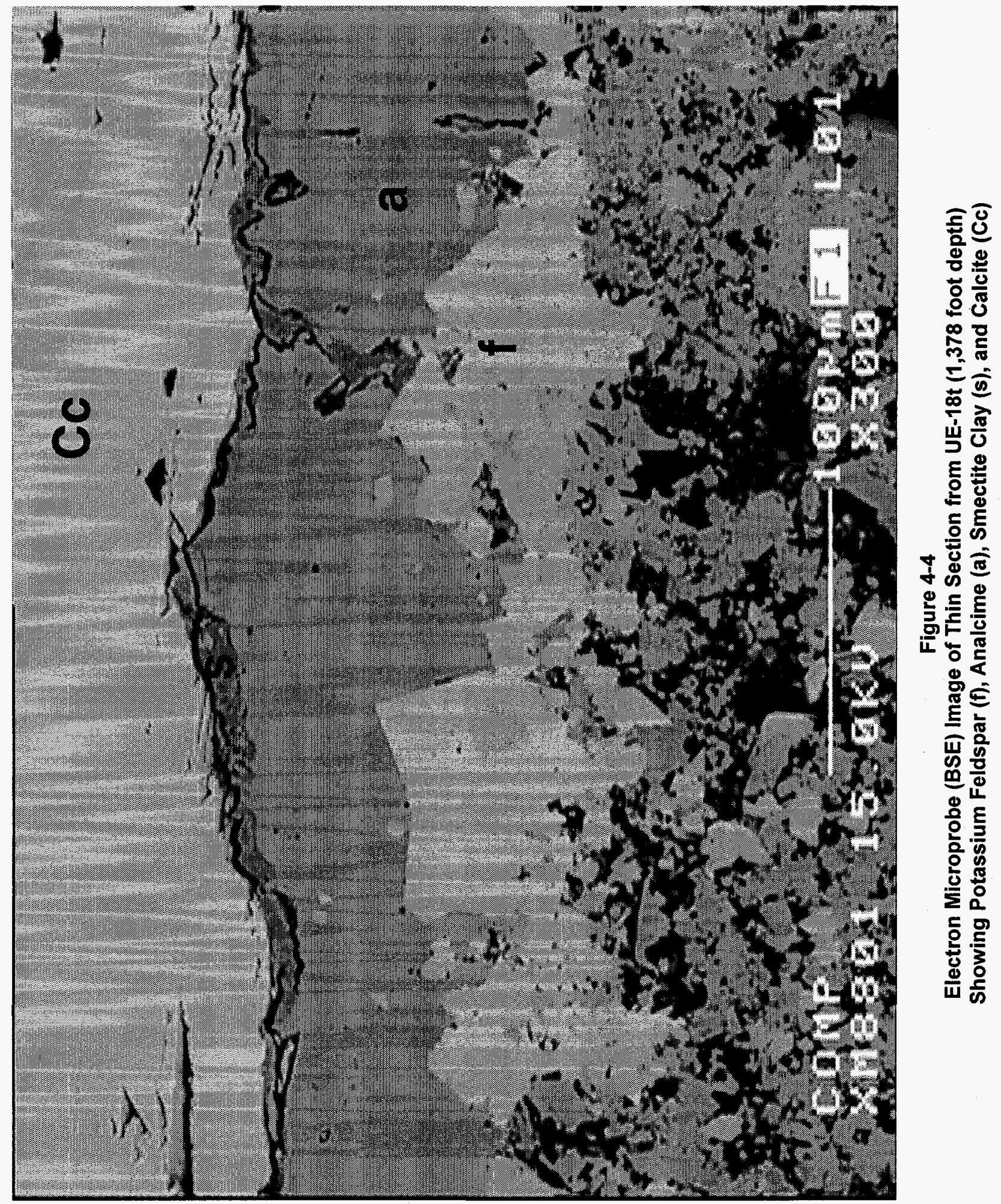


along both the major fracture surface and small cross-cutting fractures. Smectite deposition is followed by the deposition of calcite, which is also shown in Figure 4-1. Quantitative electron microprobe point analyses for the alkali feldspar, potassium feldspar, analcime, and smectite are listed in Table 4-1.

Table 4-1

Electron Microprobe Results (in weight percent oxide) for Point Analyses of Selected Specific Phases in Drill Core Samples from Pahute Mesa

\begin{tabular}{|c|c|c|c|c|c|c|c|c|c|c|c|c|}
\hline Sample Description & $\mathrm{Na}_{2} \mathrm{O}$ & MgO & $\mathrm{Al}_{2} \mathrm{O}_{3}$ & $\mathrm{SiO}_{2}$ & $\mathrm{~K}_{2} \mathrm{O}$ & $\mathrm{CaO}$ & FeO & Mno & $\mathrm{TiO}_{2}$ & $\mathrm{BaO}$ & Sro & Total \\
\hline UE-18t, $1,378 \mathrm{ft}$, alkali feldspar & 7.21 & ND & 19.25 & 66.23 & 6.43 & 0.47 & 0.17 & ND & 0.05 & ND & ND & 99.81 \\
\hline $\begin{array}{l}\text { UE-18t, } 1,378 \mathrm{ft} \text {, potassium } \\
\text { feldspar }\end{array}$ & ND & ND & 16.65 & 66.52 & 15.29 & ND & ND & ND & ND & ND & ND & 98.46 \\
\hline UE-18t, $1,378 \mathrm{ft}$, analcime & 12.15 & ND & 20.03 & 57.40 & 0.05 & ND & ND & 0.03 & ND & NA & NA & 89.71 \\
\hline UE-18t, $1,378 \mathrm{ft}$, smectite & 0.86 & 0.29 & 27.710 & 45.39 & 0.43 & 1.75 & 0.19 & ND & ND & ND & ND & 76.61 \\
\hline UE-18t, $1,390.5 \mathrm{ft}$, alkali feldspar & 2.73 & ND & $18.7: 3$ & 65.13 & 12.24 & 0.47 & 0.22 & ND & 0.06 & 0.21 & ND & 99.79 \\
\hline $\begin{array}{l}\text { UE-18t, } 1,390.5 \mathrm{ft} \text {, potassium } \\
\text { feldspar }\end{array}$ & 0.12 & 0.15 & 17.01 & 62.87 & 15.52 & 0.09 & 1.05 & ND & 0.08 & ND & ND & 96.89 \\
\hline UE-18t, $1,390.5 \mathrm{ft}, \mathrm{Mn}$-rich phase & 0.75 & 0.26 & 0.90 & 3.54 & 0.52 & 2.59 & 2.52 & 54.35 & 0.84 & 1.18 & 6.22 & 73.67 \\
\hline $\begin{array}{l}\text { UE-18t, } 1,399 \mathrm{ft} \text {, potassium } \\
\text { feldspar }\end{array}$ & 0.09 & ND & 17.81 & 66.72 & 15.91 & ND & ND & ND & ND & ND & ND & 100.53 \\
\hline UE-18t, $1,399 \mathrm{ft}$, analcime & 10.89 & ND & 18.73 & 60.01 & 0.03 & ND & ND & ND & ND & ND & ND & 89.71 \\
\hline $\begin{array}{l}\text { UE-18t, } 2,002 \mathrm{ft} \text {, fracture } A \\
\text { Fe-oxide }\end{array}$ & 0.53 & ND & $1.7 \mathrm{~s}$ & 4.63 & 0.12 & 0.27 & 78.84 & 0.11 & 1.48 & ND & ND & 87.77 \\
\hline $\begin{array}{l}\text { UE-18t, } 2,002 \mathrm{ft} \text {, fracture A } \\
\text { Fe-oxide }\end{array}$ & 0.08 & ND & 1.03 & 2.56 & 0.06 & 0.29 & 80.12 & 0.09 & 1.37 & ND & ND & 85.60 \\
\hline UE-18t, $2,020 \mathrm{ft}$, alkali feldspar & 4.50 & ND & 19.71 & 64.45 & 9.32 & 0.60 & 0.21 & ND & 0.12 & 1.59 & ND & 100.50 \\
\hline UE-18t, 2,020 ft, illite/smectite & 3.76 & 0.06 & 14.47 & 51.62 & 6.97 & 0.25 & 1.34 & ND & 0.15 & ND & ND & 78.62 \\
\hline PM-2, 6,750 ft, epidote & ND & 0.14 & 27.19 & 37.35 & 0.03 & 23.70 & 6.99 & 0.45 & ND & ND & ND & 95.85 \\
\hline PM-2, 6,750 ft, potassium feldspar & 0.54 & ND & 18.77 & 63.56 & 14.89 & 0.64 & 0.17 & ND & ND & 0.90 & ND & 99.47 \\
\hline PM-2, 6,750 ft, plagioclase & 4.58 & 0.06 & 29.36 & 55.60 & 0.33 & 10.59 & ND & ND & ND & ND & 0.09 & 100.62 \\
\hline PM-2, 8,050 ft, chlorite & ND & 21.31 & 20.24 & 29.61 & 0.16 & 0.10 & 15.63 & 0.79 & ND & ND & ND & 87.84 \\
\hline PM-2, 8,050 ft, potassium feldspan & 0.35 & ND & 18.54 & 64.64 & 16.08 & 0.05 & ND & ND & ND & 0.66 & ND & 100.32 \\
\hline
\end{tabular}

Replicate analyses of standards indicate a relative analytical precision of better than $\pm 1 \%(1)$ for major elements and a precision equal to counting statistics for minor elements. Detection limits are typically 0.05 weight percent for all elements except for $\mathrm{BaO}$, which is 0.2 weight percent.

ND $=$ not detected, below instrumental detection limit NA $=$ not analyzed

\subsubsection{Sample from 1,390.5 Feet}

This is a sample of pumice lapilli tuff of the Ammonia Tanks Member of the Timber Mountain Group, comprising the vitric tuff aquifer of the Timber Mountain Aquifer (equivalent to the sample from 1,378 feet). 
Here the tuff is also transected by an open vertical fracture which has an aperture of 1 to 2 millimeters. The fracture surface in this interval is covered predominantly with a mixture of fine-grained calcite crystals, heulandite, and smectite clay. Large platy calcite crystals, similar to those seen in the 1,378 foot interval, are also present in this sample. As shown in Figure 4-5, euhedral crystals of apatite $\left[\mathrm{Ca}_{4}\left(\mathrm{PO}_{4}\right)_{3}(\mathrm{OH}, \mathrm{F}, \mathrm{Cl})\right]$ are locally present along the fracture surface.

Thin section evaluation of the sample from this depth interval indicates that the platy calcite crystals are locally corroded and coated with a thin (approximately 10 microns) fine-grained veneer of predominantly smectite clay, mixed with quartz, alkali feldspar, potassium feldspar, and a poorly defined (at this scale) manganese-rich phase that is either a manganese-rich clay mineral or a mixed oxide-clay. Electron microprobe point analyses for the alkali feldspar, potassium feldspar, and manganese-rich phase present within this veneer are listed in Table 4-1.

\subsubsection{Sample from 1,399 Feet}

This is a sample of pumice lapilli tuff of the Ammonia Tanks Member of the Timber Mountain Group, comprising the vitric tuff aquifer of the Timber Mountain Aquifer (equivalent to samples from 1,378 and $1,390.5$ feet). At this depth interval the tuff is also transected by a vertical fracture with an open aperture of approximately 1 to 2 millimeters. Calcite on this fracture is present as relatively fine-grained rhombs with opaline silica associated with smectite clay (Figure 4-6). As shown in Figure 4-7, the dominant fracture coating phase is relatively coarse-grained ( 0.1 to 0.25 millimeters), typically euhedral, crystals of analcime $\left[\mathrm{Na}\left(\mathrm{AlSi}_{2} \mathrm{O}_{6}\right) \cdot \mathrm{H}_{2} \mathrm{O}\right]$ with spotty growths of opaline silica. The analcime crystals are occasionally corroded and partially filled with later opaline silica and typically euhedral rhombs of calcite (Figure 4-8).

A BSE image of a thin section (Figure 4-9) shows the eroded analcime which is initially intergrown with potassium feldspar around an apatite-rich core, growing on the rock matrix into the fracture space. Electron microprobe point analyses for the potassium feldspar and the analcime are listed in Table 4-1.

\subsubsection{Sample from 2,002 Feet}

This is a sample of welded ash-flow tuff of the Rainier Mesa Member of the Timber Mountain Group, comprising the welded tuff aquifer of the Timber Mountain Aquifer. A single piece of core (approximately eight centimeters in length) has two filled fractures transecting it at moderate (40 to 50 degree) angles, one on each end of the sample. The 


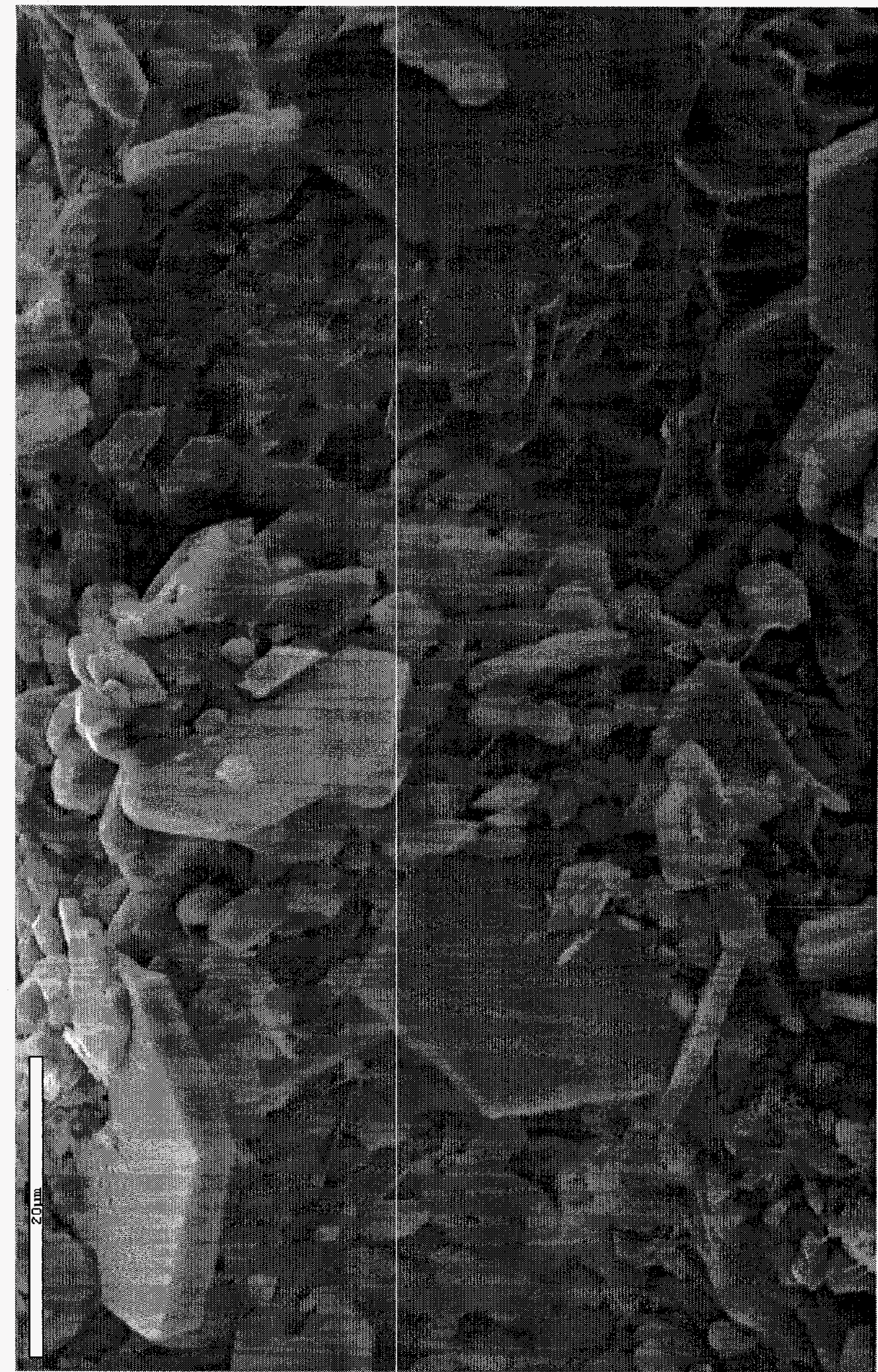

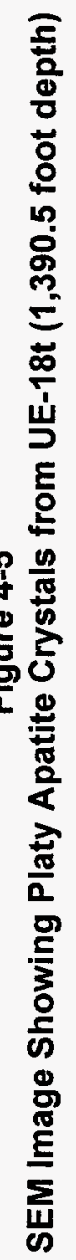




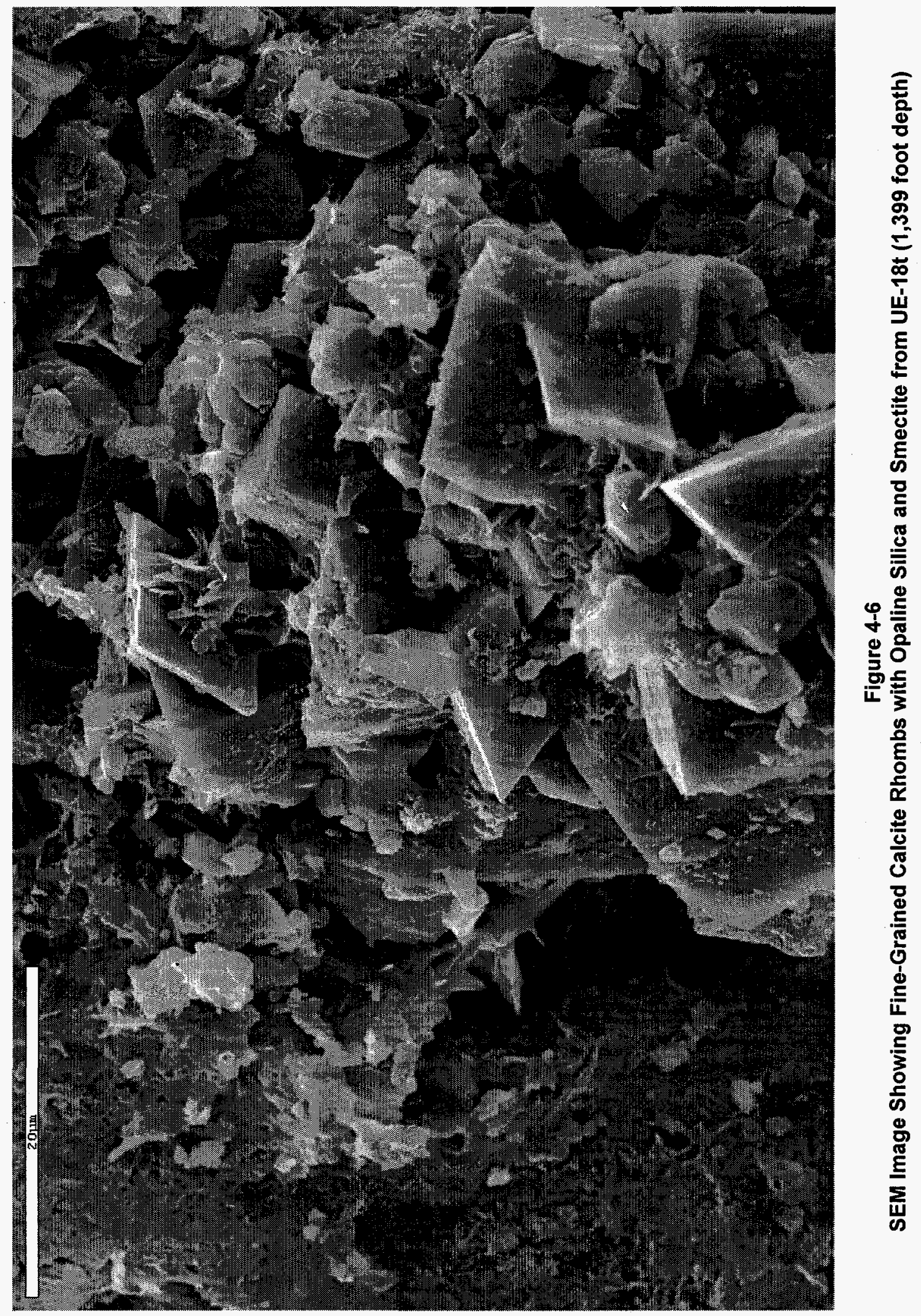




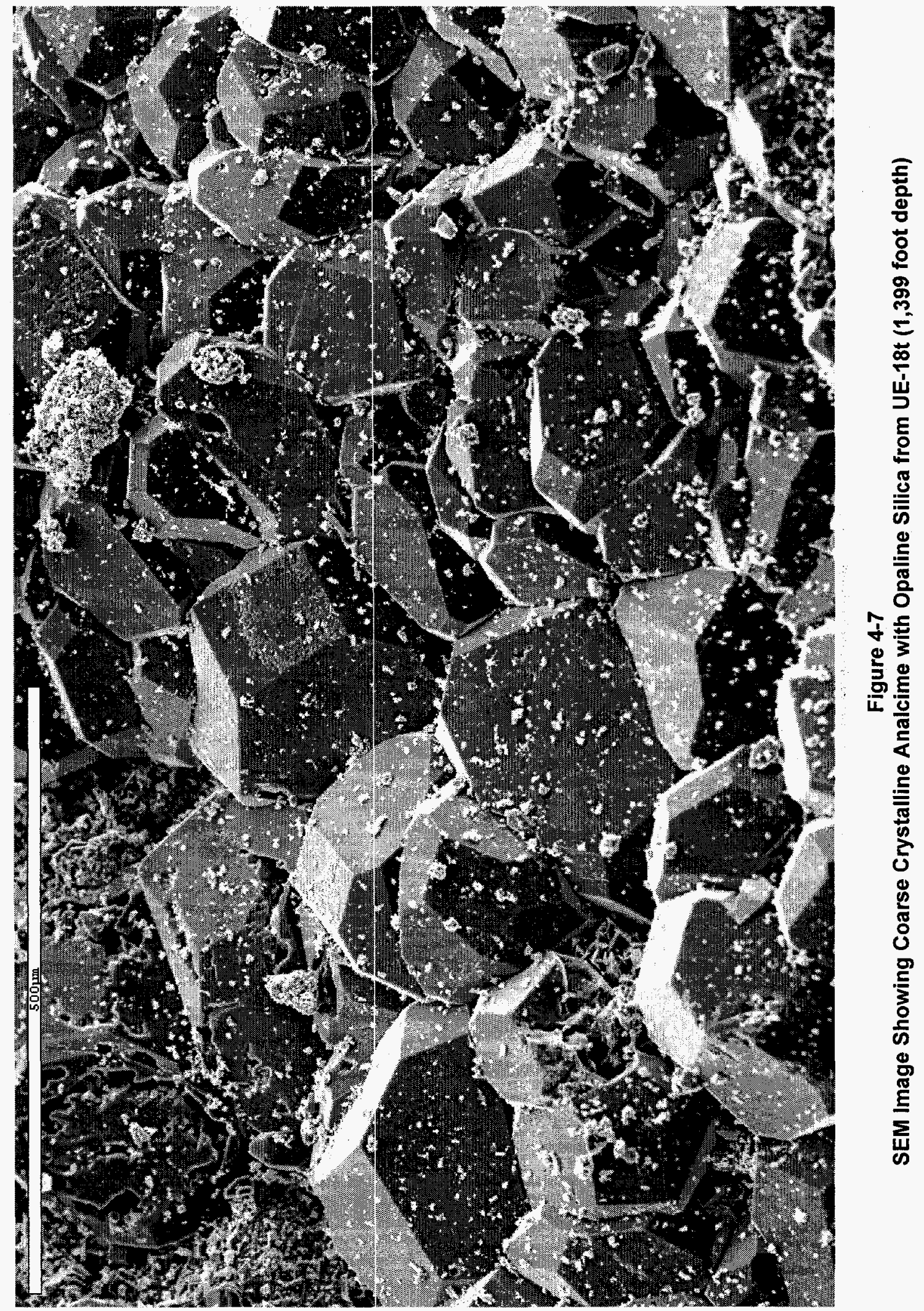




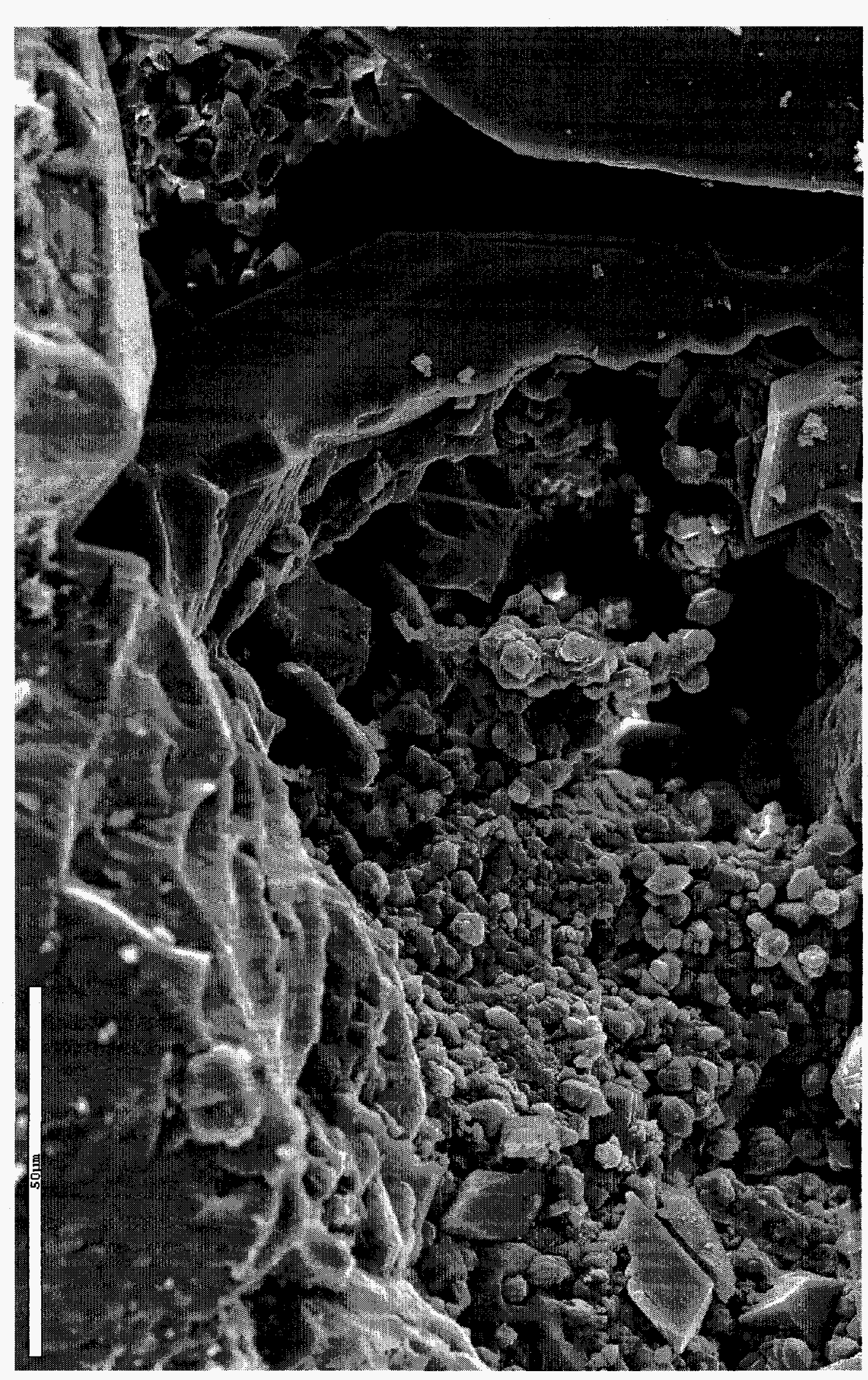

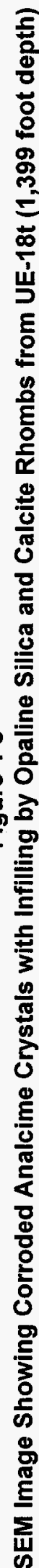




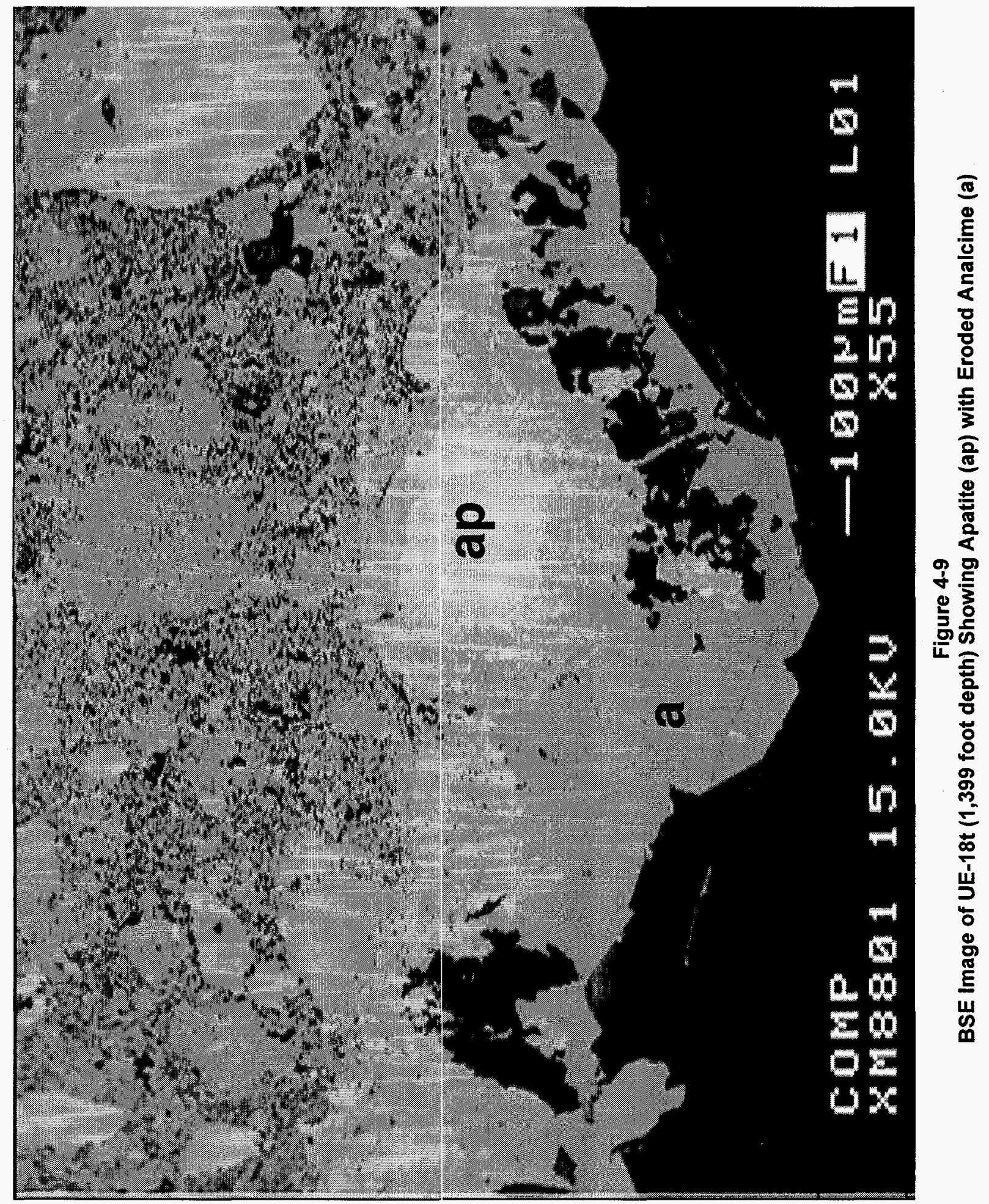


attitudes of the fractures are intersecting, however, they do not intersect in this sample. The uppermost fracture has been labeled ' $A$ ', and the lower fracture has been labeled 'B.' In hand specimen, fracture $A$ appears to be comprised predominantly of calcite and clay minerals, while fracture $B$ is dominated by dark grayish-black to red oxides with lesser clay minerals. Both fractures appear to have no open aperture.

In Figure 4-10, eroded and slightly pitted calcite is locally overgrown by smectite on fracture A. The EDS analysis of the calcite, conducted on the SEM, indicates it to be manganiferous. A BSE image of a thin section across fracture A (Figure 4-11) shows the rock matrix with a thin coating of iron-oxide (probably mixed with a small amount of clay) and the later calcite which essentially fills the principal fracture as well as a smaller fracture that trends up and to the left in the image. The quartz and feldspar in the lower left of the image are assumed to be part of the rock matrix. Electron microprobe point analyses of the iron-oxide rich phase are included in Table 4-1.

Fracture B is coated predominantly with a hematite/smectite mixture with lesser amounts of eroded and pitted calcite (Figure 4-12). As shown in Figure 4-13, smectite is also present as a delicate web formed between the calcite and the oxide/clay mixture. The BSE image of a thin section through fracture B (Figure 4-14) shows phase relations similar to those seen on fracture $A$; however, the oxide rich portion of the fracture coating is better developed and more exposed on fracture $B$.

\subsubsection{Sample from 2,020 Feet}

This is a sample of welded ash-flow tuff of the Rainier Mesa Member of the Timber Mountain Group, comprising the welded tuff aquifer of the Timber Mountain Aquifer. The host lithology in this sample is equivalent to the host rock at the 2,002 foot interval described above. The sample is transected by a relatively thick (approximately 5 millimeters) fracture coating comprised predominantly of calcite. The fracture coating is layered, with the 2 millimeters closest to the host rock consisting of interlocking manganiferous calcite crystals up to 1 millimeter in size, overlain by 3 millimeters of manganiferous calcite crystals in a matrix of weakly iron-stained clay. No SEM images were taken of this sample.

A BSE image (Figure 4-15) taken of a thin section from this sample shows the dense, interlocking calcite crystals becoming less dense and intergrown with illite/smectite with increasing distance from the host rock matrix. Also present on or near the fracture surface are quartz, alkali feldspar, ilmenite, and biotite. The quartz, illite, and calcite appear to have a coherent spatial and textural association with the fracture, while the corroded appearance of the ilmenite, feldspar, and biotite suggests that they are either rock matrix components or relicts 


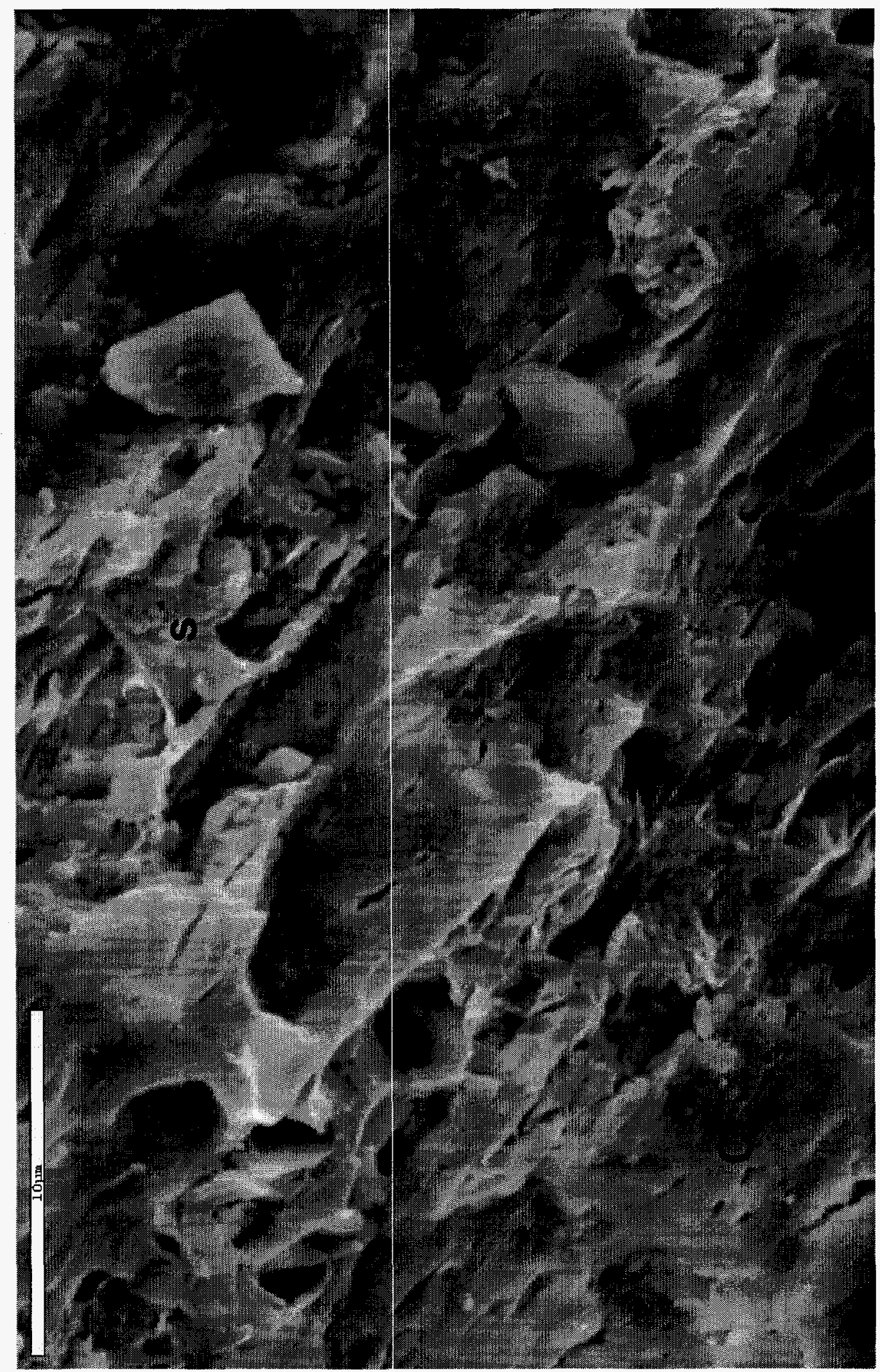

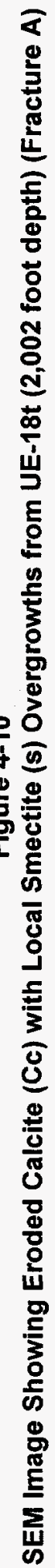




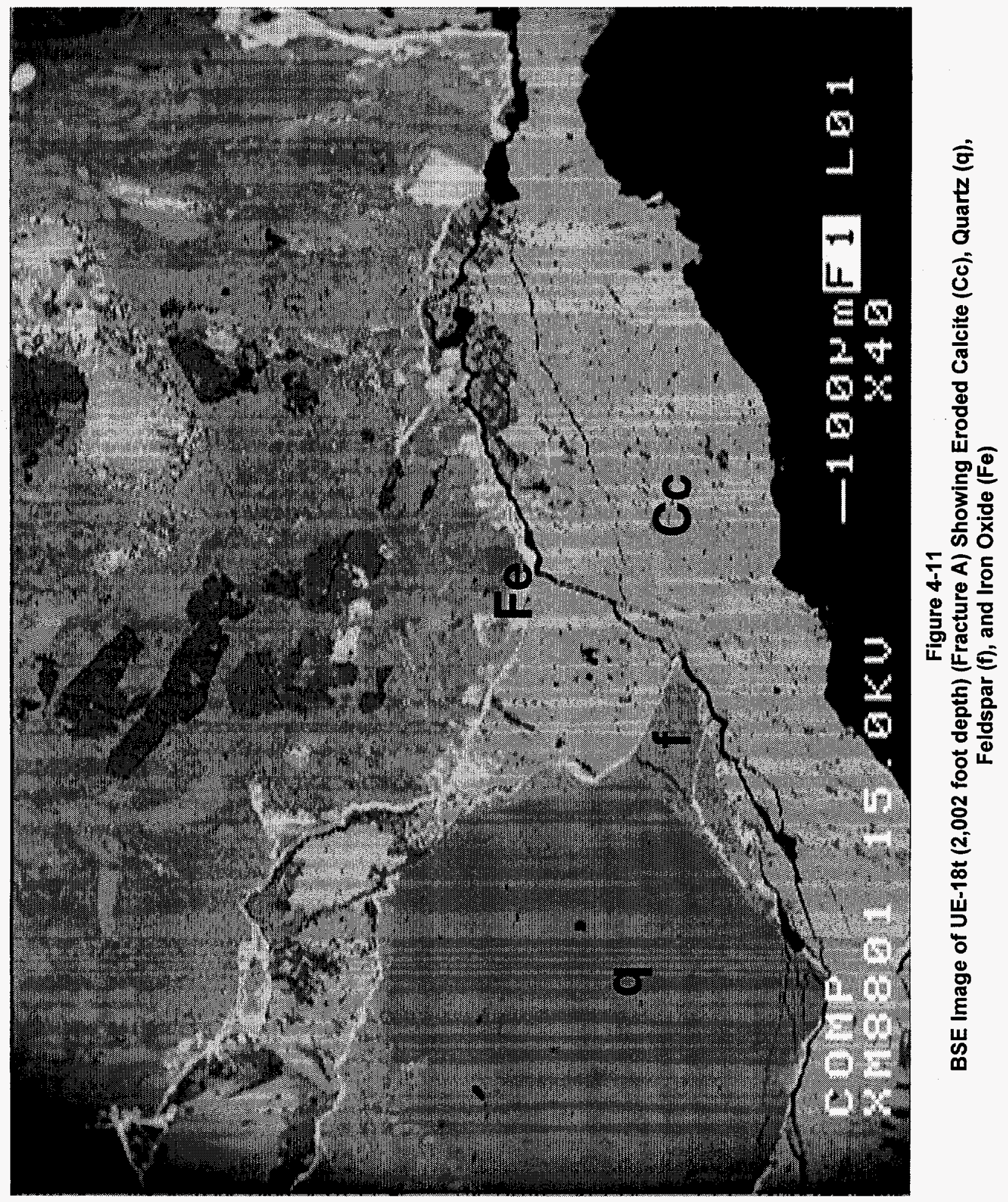




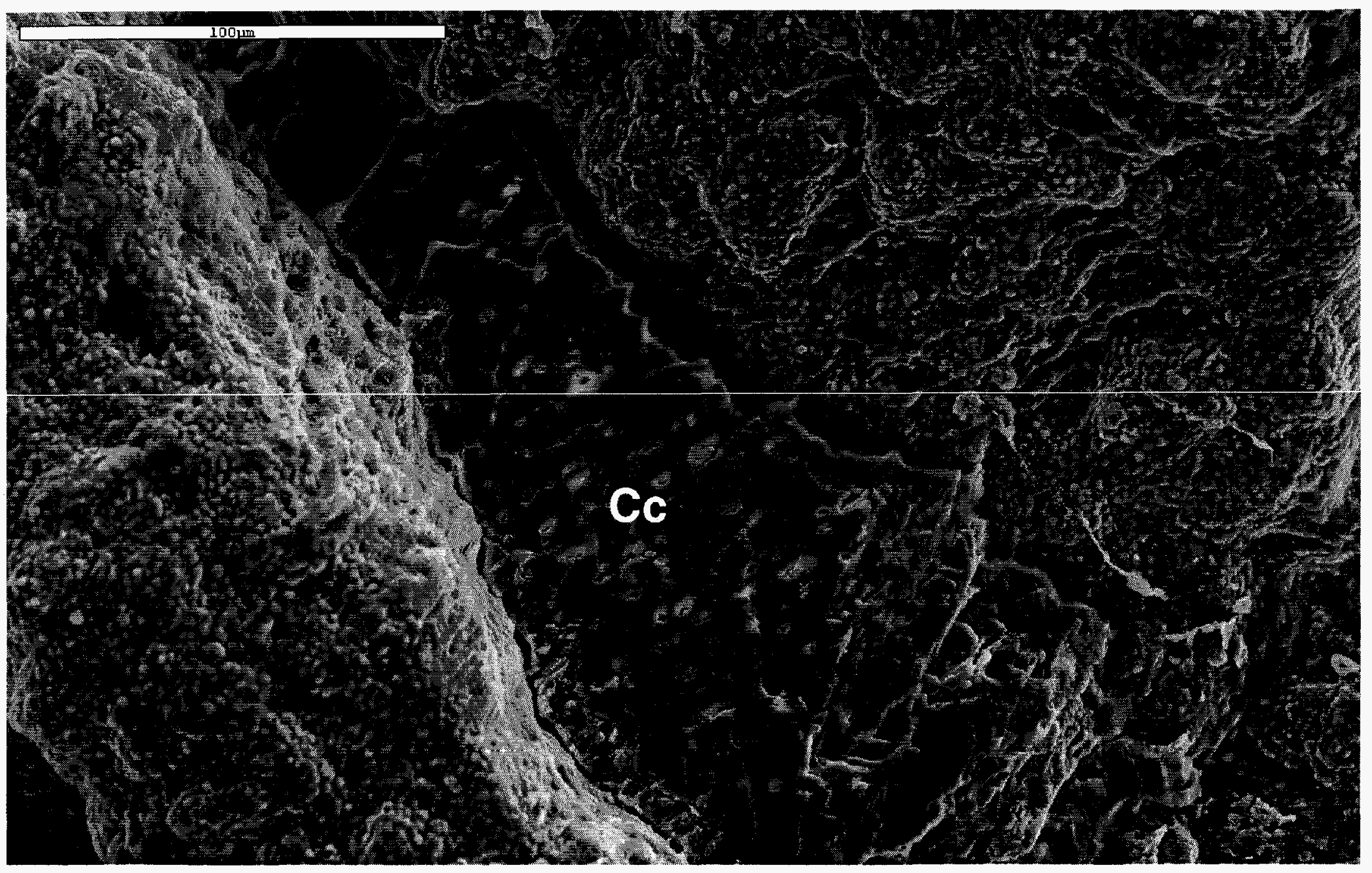

Figure 4-12

SEM Image Showing Pitted and Eroded Calcite (Cc) Adjacent to Mixed Hematite and Smectite from UE-18t (2,002 foot depth) (Fracture B) 


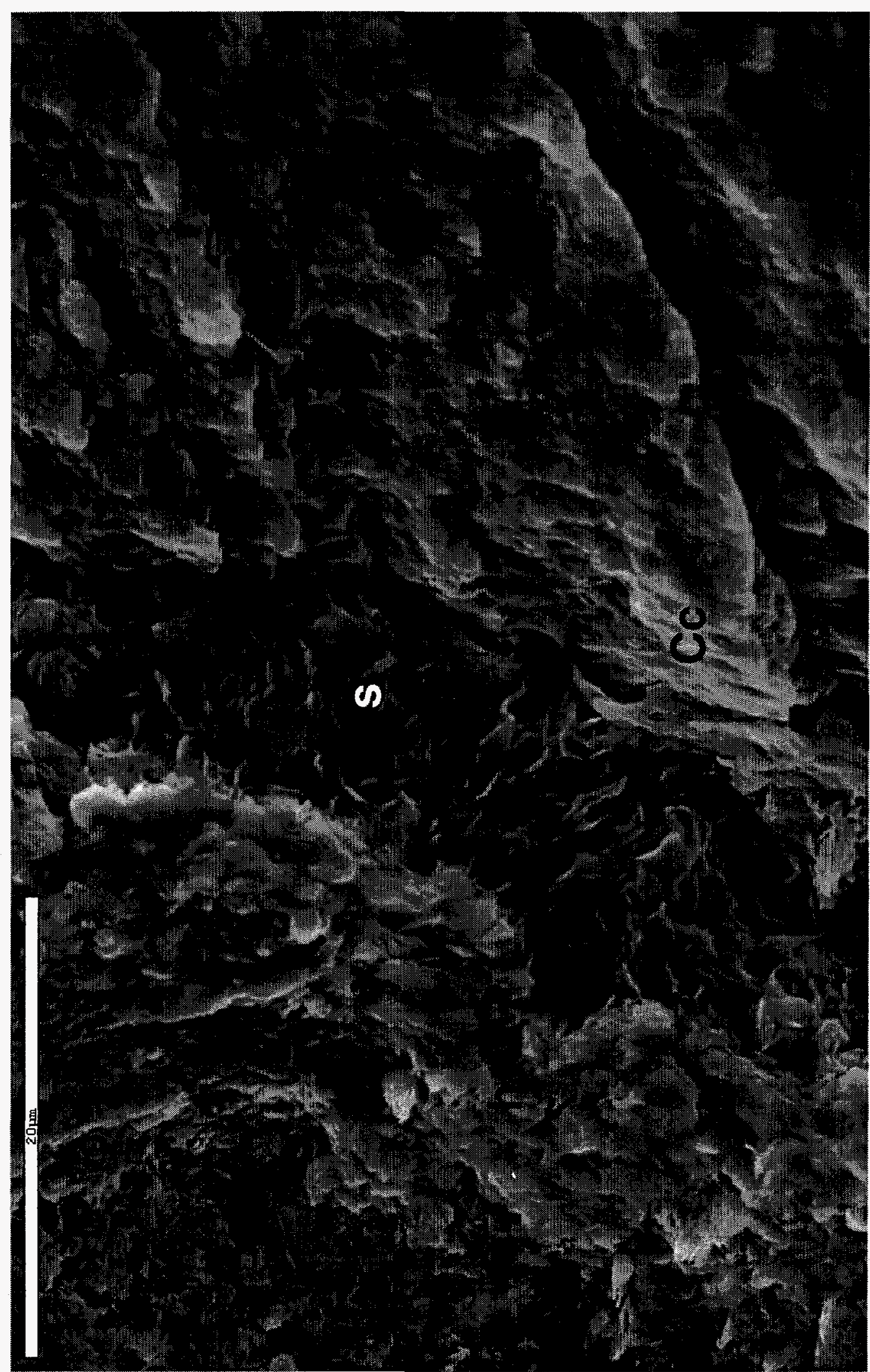

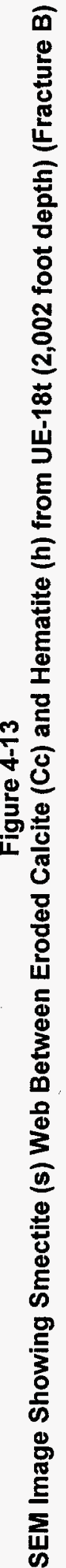

7) 


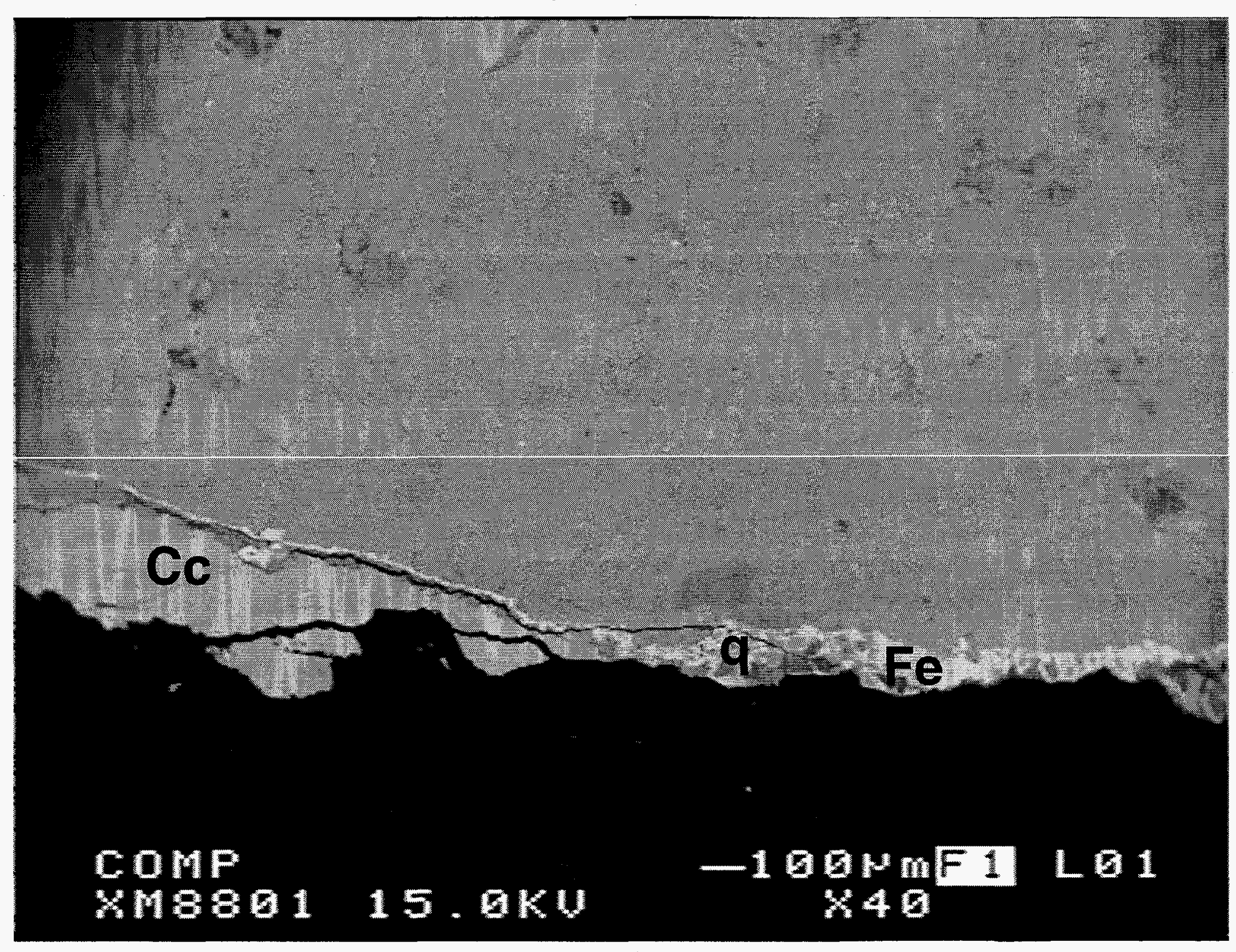




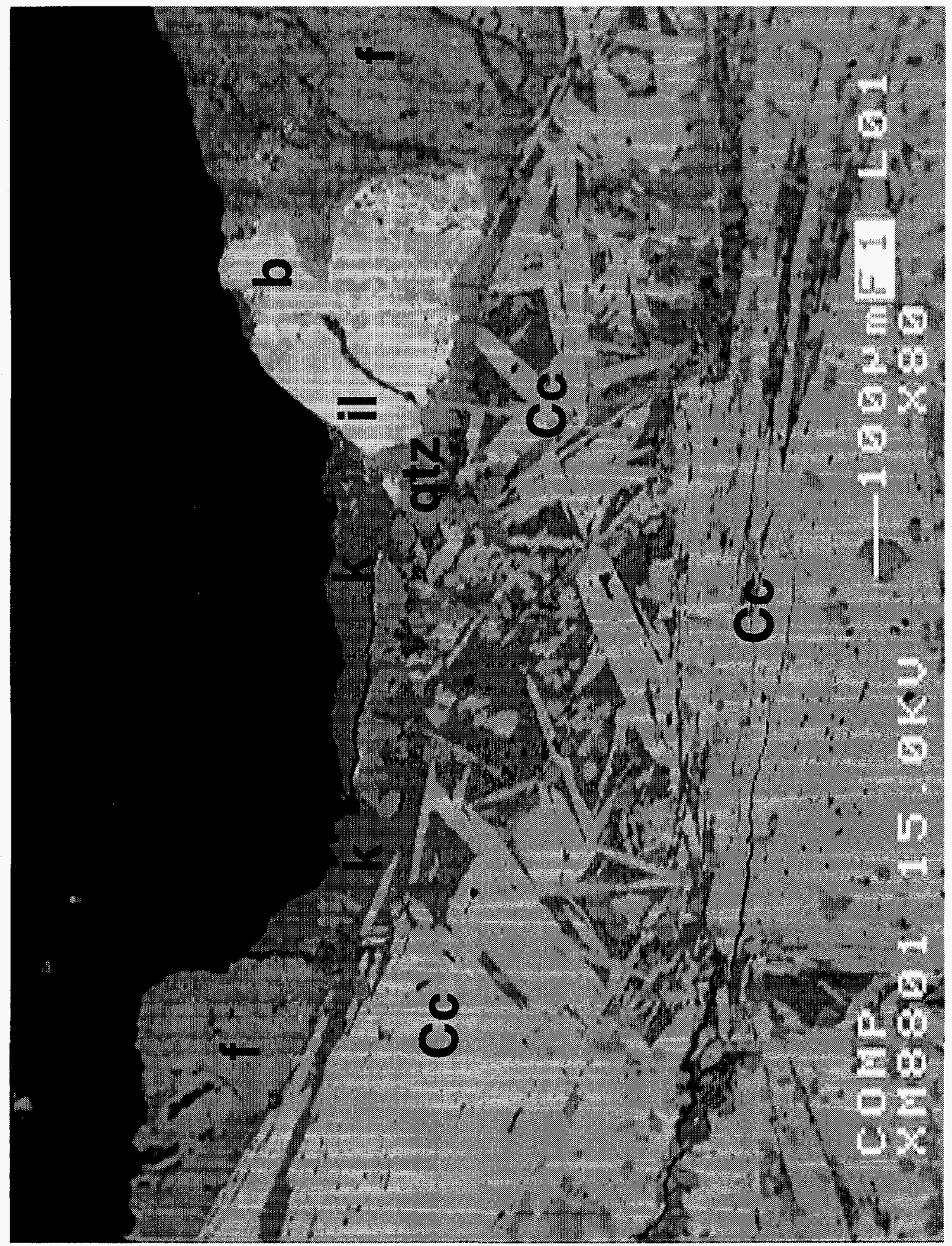

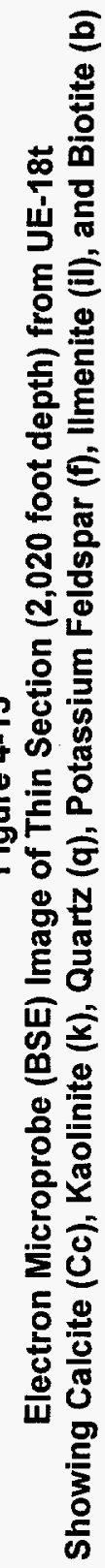


from an earlier alteration event. Electron microprobe point analyses for the alkali feldspar and illite/smectite are included in Table 4-1.

The HRTEM analysis (Appendix A) of the fine-grained clay-rich material interspersed with the coarser calcite crystals indicates the presence of calcite, quartz, smectite, and a fine-grained ( $<2$ microns) iron-oxide identified, based on a sleeted area electron diffraction (SAED) pattern, as akaganeite $(\gamma \mathrm{FeOOH}$, with a hollandite structure).

\subsubsection{Sample from 2,583 Feet}

This is a sample of welded ash-flow tuff of the Rainier Mesa Member of the Timber Mountain Group, comprising the welded tuff aquifer of the Timber Mountain Aquifer. The host lithology in this sample is equivalent to the host rock at the 2,002 and 2,020 foot intervals described above, although, as indicated in the lithologic log, the degree of welding increeses with depth. Three separate but similar fracture features are present at this depth interval. Thin (approximately 1 to 2 millimeters), largely filled calcareous fractures with chlorite (?), and clay minerals cut the sample with intersecting attitudes. A SEM image (Figure 4-16) of one of these fractures shows it is coated predominantly with ragged plates of illite. No electron microprobe analyses were conducted on this sample.

\subsection{Drill Hole U-19ar}

U-19ar was the emplacement hole drilled for the CYBAR test. The hole has a total depth of 2,200 feet and only washed cuttings and percussion gun sidewall cores are available. The drill hole is completed within the Timber Mountain Aquifer and elements of the Upper Paintbrush Composite Unit. The two intervals sampled consist of vitric tuff aquifer from the Pahute Mesa Tuff of the Thirsty Canyon Group, and the Pool Member of the Timber Mountain Group, both within the Timber Mountain Aquifer hydrostratigraphic unit (Drellack et al., 1997). While no preserved fracture coatings were noted in this drill hole, two percussion gun sidewall cores were selected from the archived material based on information contained in Warren et al. (1998) that these intervals had sufficient carbonate material for isotopic analysis (Rose et al., 1998). The soft, friable nature of the samples from this drill hole resulted in sample charging during SEM analysis, and consequently pocr image resolution.

\subsubsection{Sample from 173 Feet}

This is a sample of calcareous, reworked pumiceous tuff of the Pahute Mesa Member of the Thirsty Canyon Group, comprising the vitric tuff 


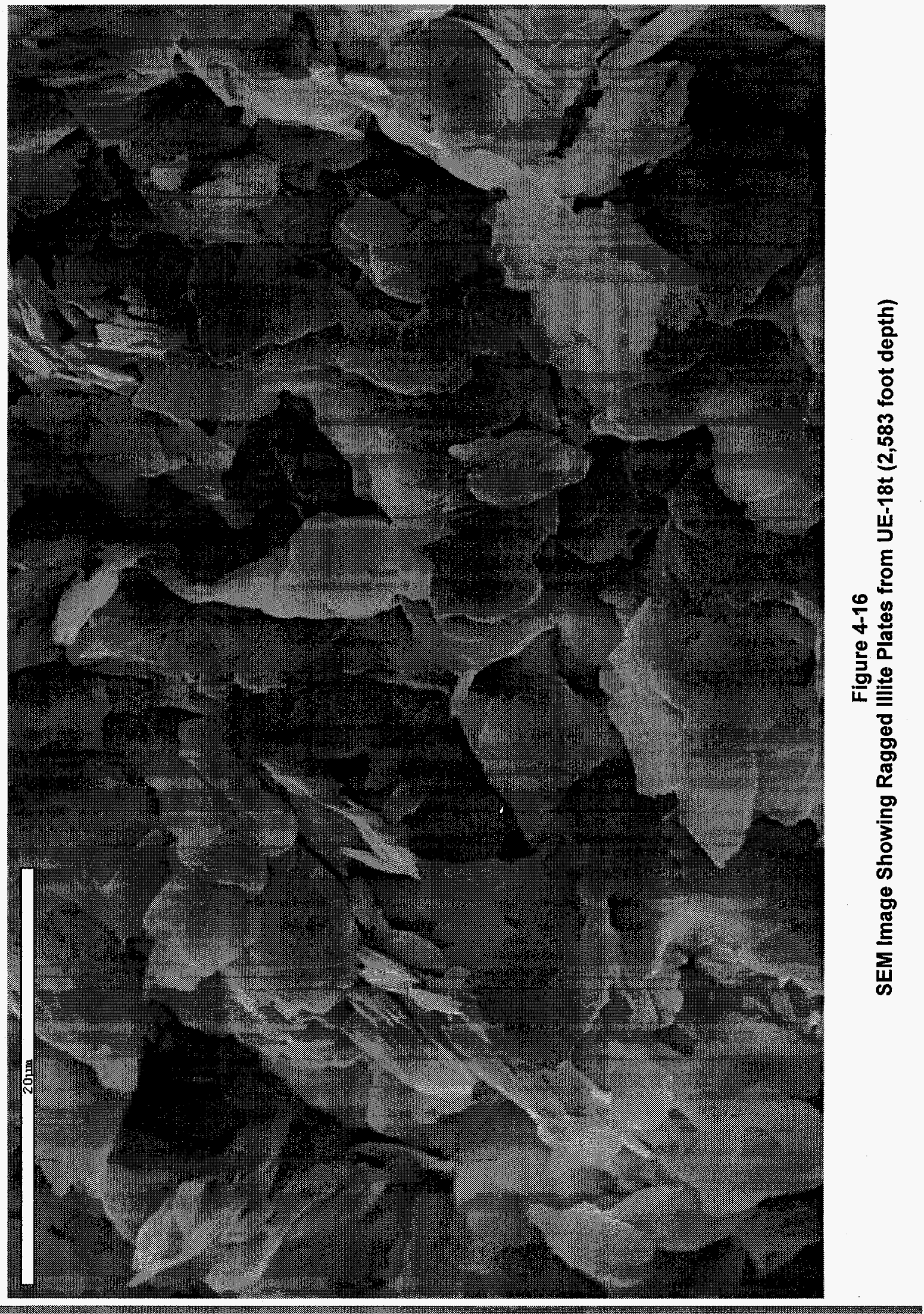


aquifer of the Timber Mountain Aquifer. Calcite is present as very fine grained disseminations in the sample matrix and appears to be concentrated in lapilli fragments. A SEM image (Figure 4-17) of a fresh sample surface shows a thin veil of smectite clay on an eroded glass substrate. Analysis of this sample with the SEM was complicated by the fact that the electron beam induced sample decomposition. This is due to the friable nature of the material. No micrographic confirmation of calcite properties was obtained. No microprobe analyses were conducted on this sample.

\subsubsection{Sample from 1,560 Feet}

This is a sample of calcareous, reworked pumiceous tuff of the Pool Member of the Timber Mountain Group, comprising the vitric tuff aquifer of the Timber Mountain Aquifer. Calcite is present as very fine grained disseminations in the sample matrix and appears to be concentrated in lapilli fragments. A SEM image (Figure 4-18) of a fresh sample surface shows incipient smectite clay development on a glassy lapilli fragment. Analysis of this sample with the SEM was also complicated by electron beam induced sample decomposition due to the friable nature of the material. No micrographic confirmation of calcite properties was obtained. No microprobe analyses were conducted on this sample.

\subsection{Drill Hole UE-20f}

Exploratory hole UE-20f was drilled in 1964 in the west-central part of Area 20. This hole was drilled as part of a program to explore individual sites on Pahute Mesa prior to drilling emplacement holes (Carroll, 1966). 'The drill hole has a total depth of 13,686 feet (currently the deepest hole at NTS) and was intermittently cored over the interval from 739 to 13,636 feet. A total of 50 core runs were conducted with 394 feet of core recovered (Drellack et al., 1997). Two fractured samples were collected from this drill hole archive: one from the Lava of Split Ridge of the Belted Range Group, comprising the lava flow aquifer of the Belted Range Aquifer, and one from the Volcanics of Oak Spring Butte, comprising the welded tuff aquifer of the Basal Aquifer.

\subsubsection{Sample from 8,668 Feet}

This is a sample of light grayish-brown massive rhyolite from the Lava of Split Ridge of the Belted Range Group, comprising the lava flow aquifer of the Belted Range Aquifer. The rhyolite has been highly fractured and has very well developed $\mathrm{Fe}$ - and Mn-oxide coatings on fracture surfaces, giving the sample a reddish-brown appearance 


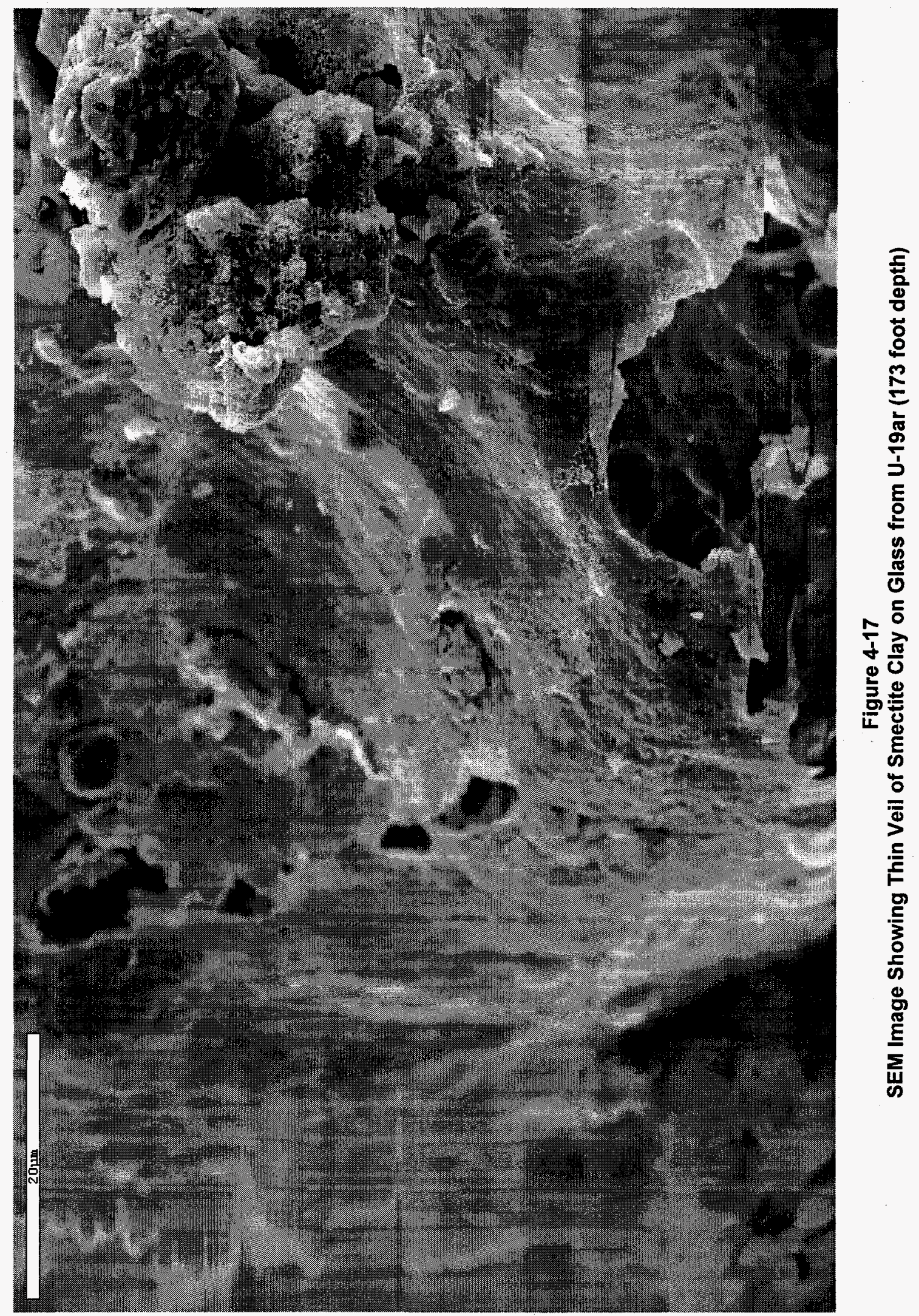




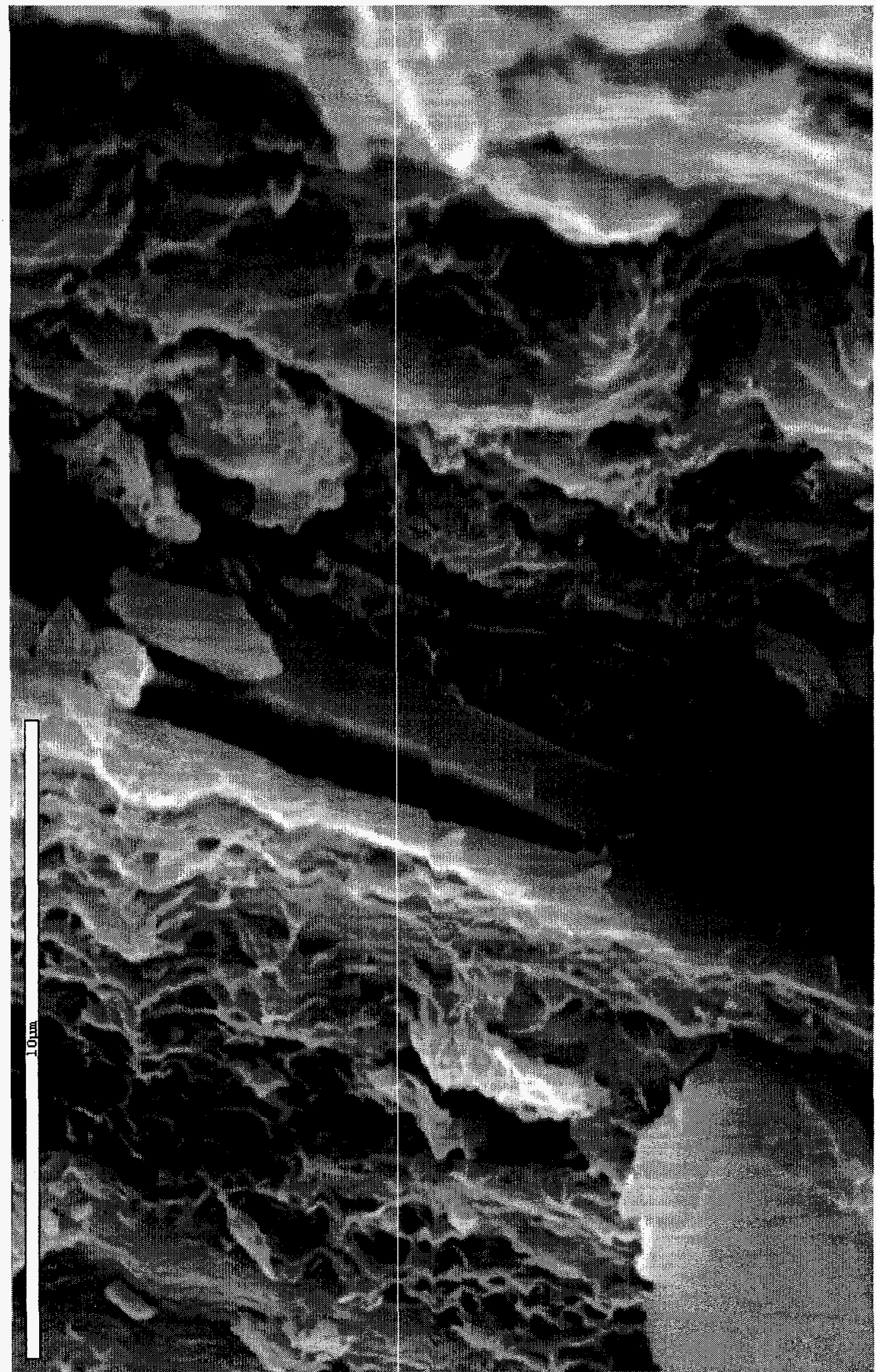

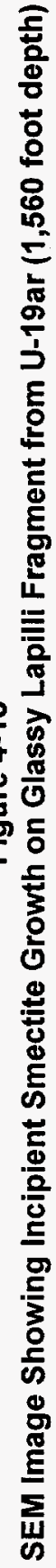


overall. As shown in Figure 4-19, the fracture coating material is very fine grained (less than 200 nanometers) and is apparently layered (Figure 4-20).

The fine grained nature of the fracture coating material from this interval made it unsuitable for analysis using either the SEM or microprobe. The HRTEM analysis complemented by X-ray diffraction (Appendix A) indicates that the fracture coating is comprised of hematite $\left[\mathrm{Fe}_{2} \mathrm{O}_{3}\right]$, quartz, illite/smectite, alkali feldspar, and a highly disordered $\mathrm{Mn}$-rich phase containing structural elements of the minerals birnessite $\left[(\mathrm{Na}, \mathrm{Ca}, \mathrm{K})_{\mathrm{x}}\left(\mathrm{Mn}^{4+}, \mathrm{Mn}^{3+}\right)_{2} \mathrm{O}_{4} \cdot \mathrm{H}_{2} \mathrm{O}\right]$, buserite, and todorokite $\left[(\mathrm{Na}, \mathrm{Ca}, \mathrm{K})_{\mathrm{x}}\left(\mathrm{Mn}^{4+}, \mathrm{Mn}^{3+}\right)_{6} \mathrm{O}_{12} \cdot 3-4.5 \mathrm{H}_{2} \mathrm{O}\right]$. Hand specimen analysis also indicates the presence of calcareous interlayers within the fracture coating as a result of effervescing in response to dilute $\mathrm{HCl}$.

\subsubsection{Sample from 13,674 Feet}

This is a sample of hydrothermally altered rhyolite lava from the Volcanics of Oak Spring Butte, comprising a lava flow aquifer from the Basal Aquifer. The rhyolite has a well-developed fracture coating assemblage comprised of quartz, calcite ( $\mathrm{Fe}$ - and $\mathrm{Mn}$-bearing), siderite $\left[\mathrm{FeCO}_{3}\right]$, chlorite, epidote, pyrite, illite/smectite, and goethite $[\alpha \mathrm{FeOOH}]$. Figure 4-21 shows blocky, uneroded calcite partially covered with a layer of mixed illite/smectite with goethite. Other portions of the fracture surface are coated by massive (chalcedonic) to sugary (microcrystalline) quartz with euhedral to subhedral pyrite cubes (Figure 4-22).

The BSE image (Figure 4-23) shows calcite (with an eroded iron-rich rim) with quartz on the fracture surface with pyrite in the rock matrix.

The HRTEM analysis (Appendix A) has identified the presence of berthierine (likely the same phase indicated as chlorite above). Berthierine $\left[\mathrm{Fe}^{2+}{ }_{2} \mathrm{Al}(\mathrm{SiAl}) \mathrm{O}_{5}(\mathrm{OH})_{4}\right]$ is a layered silicate that is compositionally similar to chlorite but structurally part of the kaolinite-serpentine group.

\subsection{Drill Hole U-20as}

U-20as was the emplacement hole drilled for the BELMONT test. The hole has a total depth of 2,099.2 feet and only washed cuttings are available. The drill hole is completed within the Timber Mountain Aquifer and elements of the Upper Paintbrush Composite Unit. The interval sampled consists of vitric tuff aquifer from the Ammonia Tanks Tuff of the Timber Mountain Group, within the Timber Mountain Aquifer. A sequence of cuttings samples was collected over a 40 foot interval, based on information contained in Warren et al. (1998) 


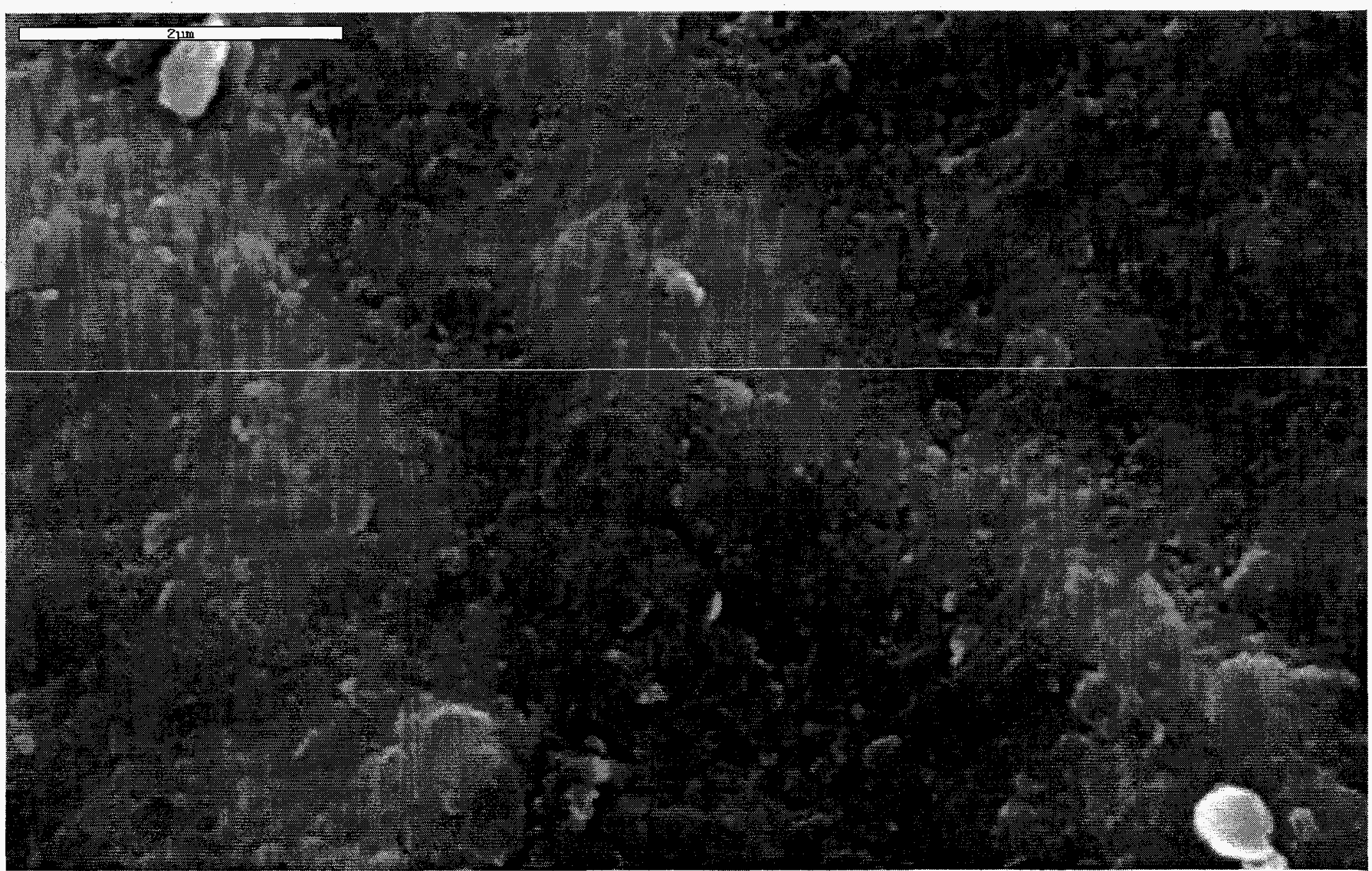

Figure 4-19

SEM Image Showing Very Fine-Grained Nature of Mixed Fracture Coating Material Comprised of Hematite, Quartz, Illite, Manganese Oxides, and Alkali Feldspars from UE-20f (8,668 foot depth) 


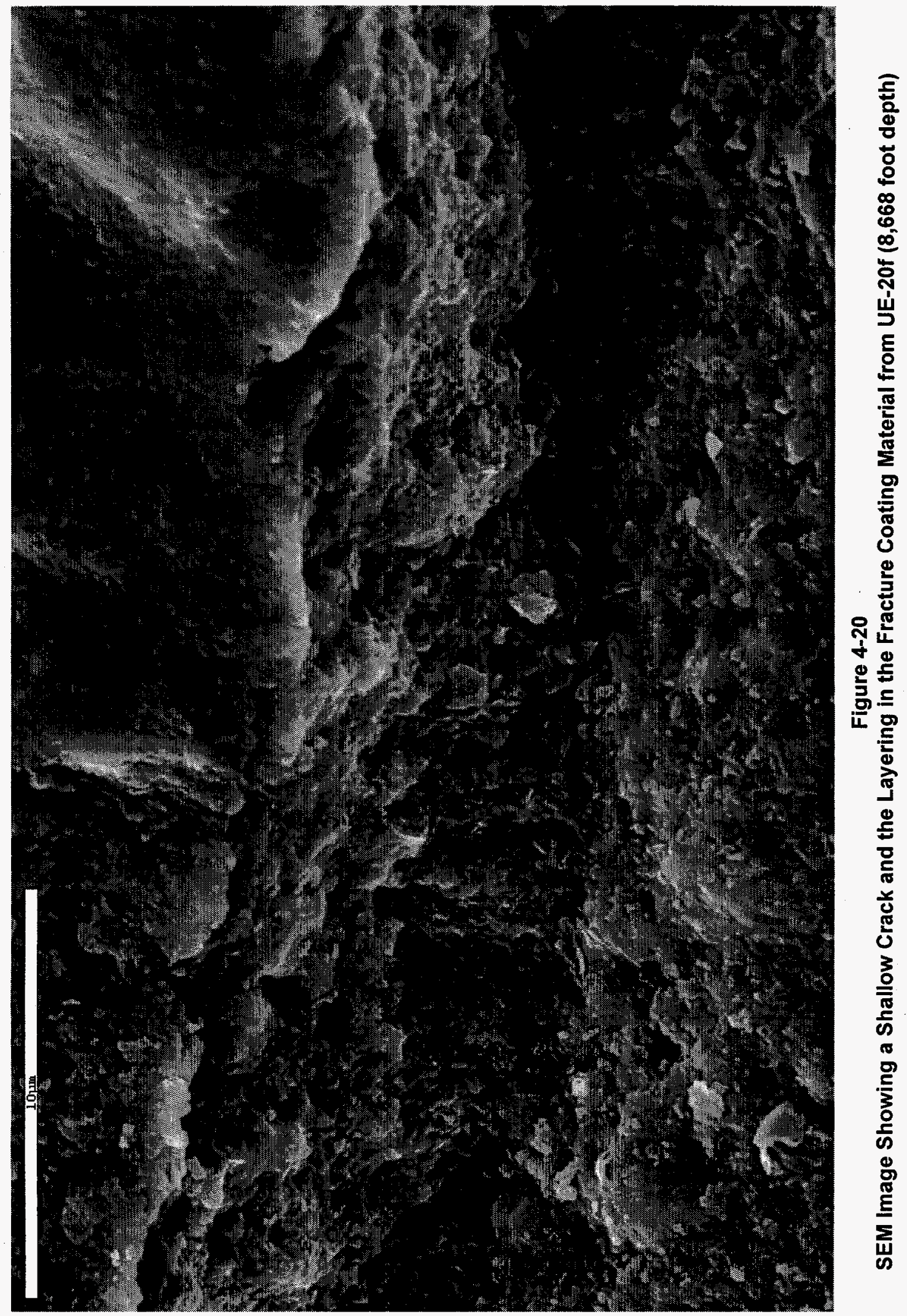

(1) 


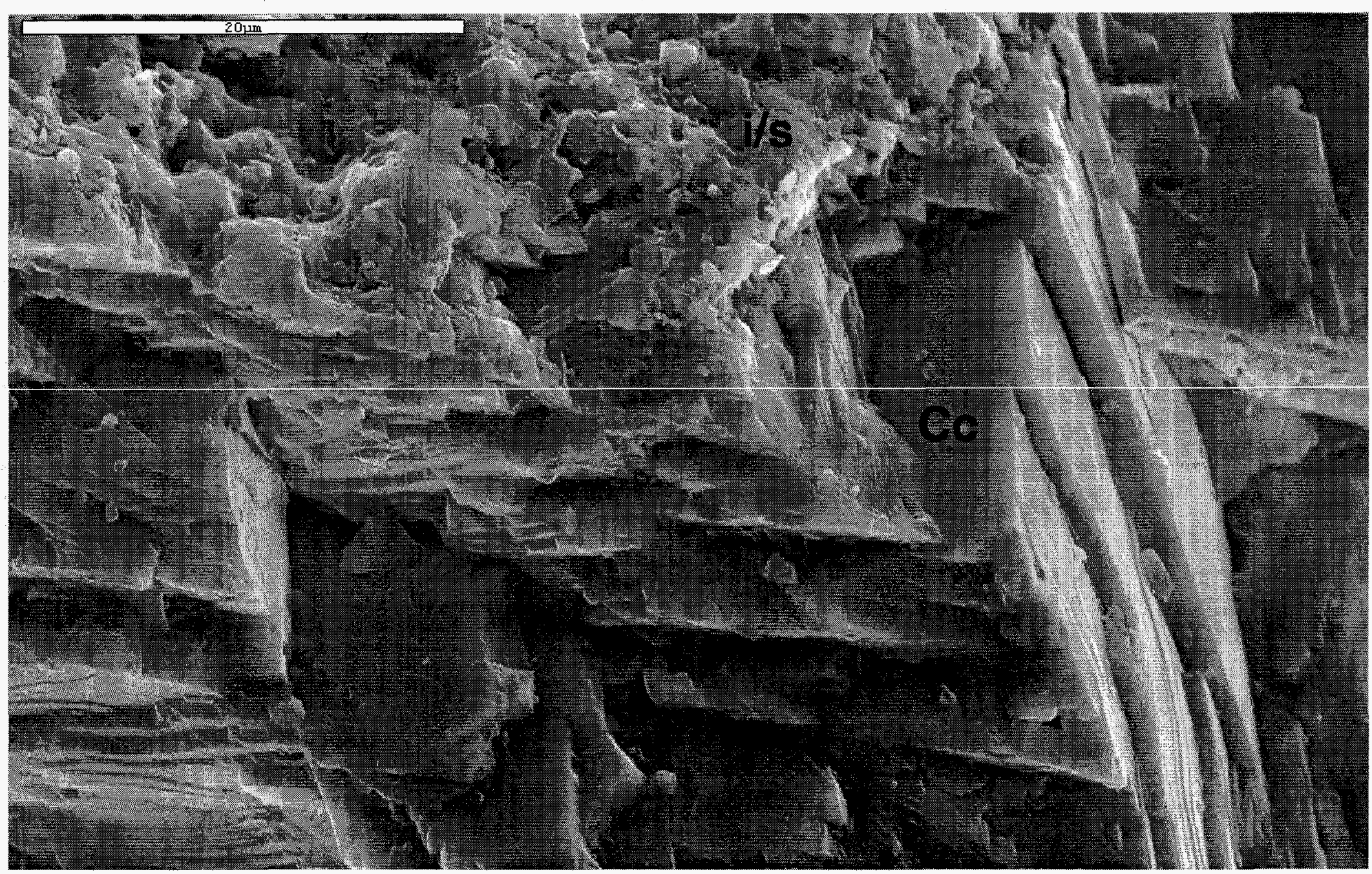

Figure 4-21

SEM Image Showing Blocky, Uneroded Calcite (Cc) with Overgrowth of Illite/Smectite (i/s) Mixed with Goethite from UE-20f (13,674 foot depth) 


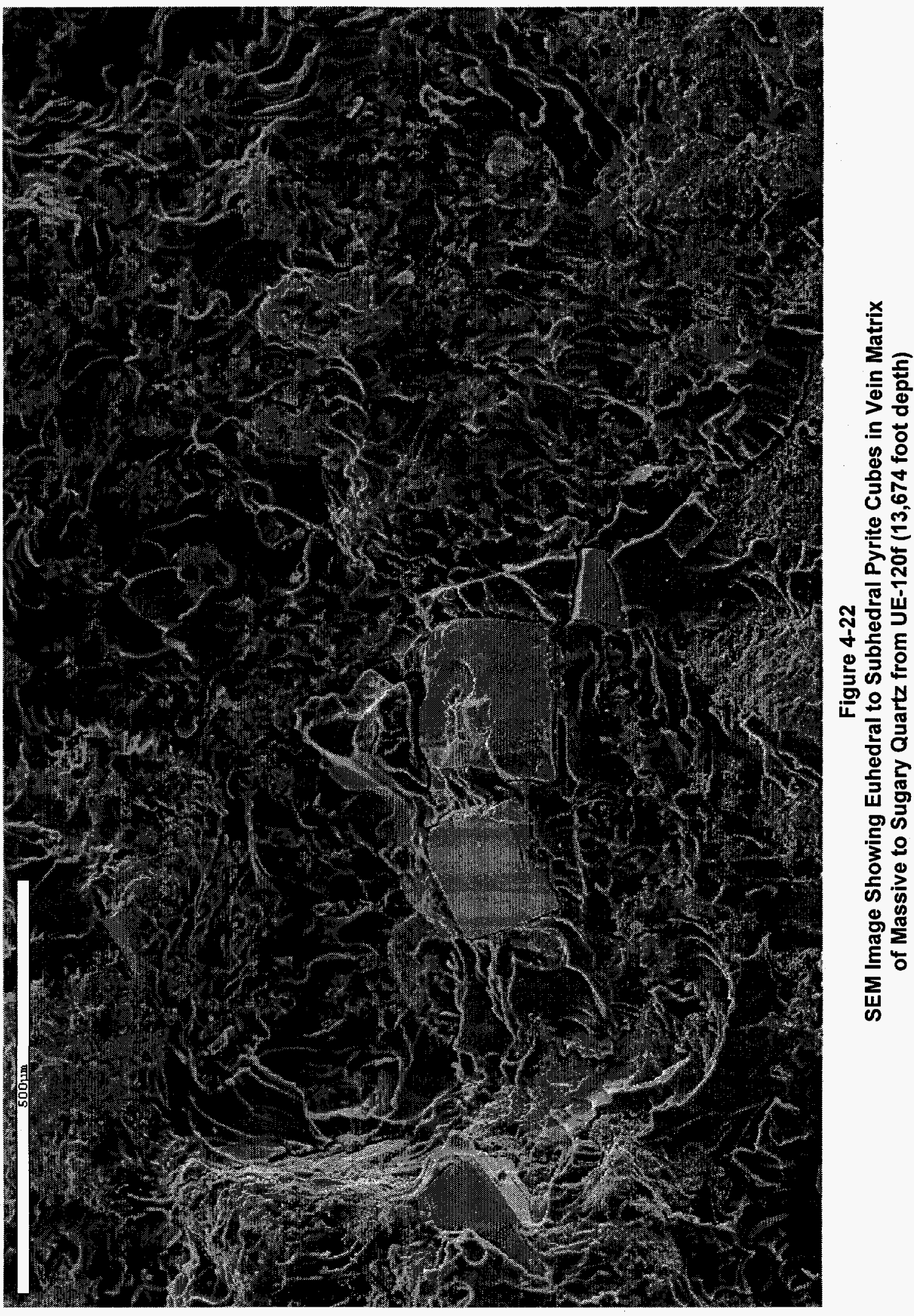




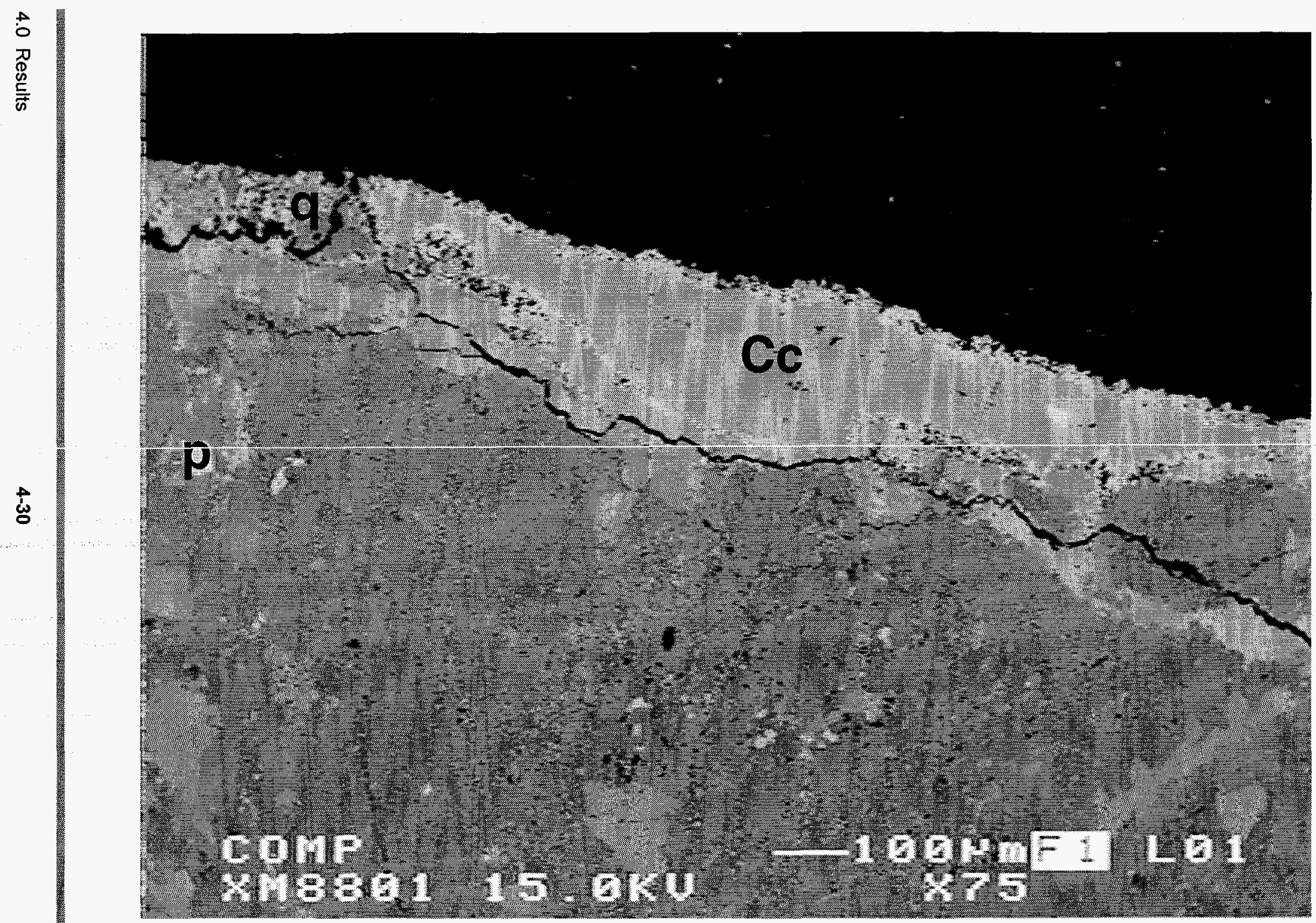

Figure 4-23

BSE Image of UE-20f (13,674 foot depth) Showing Calcite (Cc) with an Eroded Iron-Rich Rim, and Quartz (q) on Fracture Surface, with Pyrite ( $p$ ) in Rock Matrix 
that these intervals had sufficient carbonate material for isotopic analysis. A sample was collected for isotopic analysis only.

\subsubsection{Sample from 290 to 330 Feet}

This is a sample of a reworked, crystal-rich vitric tuff. Calcite appears to be present (Rose et al., 1998) as cement-like impregnations disseminated throughout the tuff matrix. No micrographic analysis of this sample was conducted.

\subsection{Drill Hole PM-2}

PM-2 is an exploratory drill hole placed in the extreme northwestern corner of the NTS. This site was chosen for sampling because of its westerly location and because of the widespread calcite identified by Warren et al. (1998) in the core. The hole has a total depth of $8,781.6$ feet and continuous cores are available. Six samples of fractured core were collected from this drill hole. One sample was collected from the Spearhead Tuff of the Thirsty Canyon Group comprising the vitric tuff aquifer of the Timber Mountain Aquifer. Four samples were collected from various lava flow aquifers within the Basal Aquifer and one sample from a brecciated granodiorite from the Basal Aquifer.

\subsubsection{Sample from 320 Feet}

This is a sample of welded tuff of the Spearhead Tuff of the Thirsty Canyon Group, comprising the vitric tuff aquifer of the Timber Mountain Aquifer. In this interval, the tuff is transected by an open fracture coated by (up to 7 millimeters thick) calcite and botryoidal opaline silica. Figure 4-24 shows botryoidal opaline silica with later overgrowths of opal. Coarse, blocky calcite is visible in the upper right hand portion of the field of view.

A thin section through the fracture coating is presented as a BSE image collected on the electron microprobe (Figure 4-25). In Figure 4-25, it is shown that calcite occurs both as a substrate for the earlier botryoidal opaline silica and as intergrowths with subsequent layers. This is even more apparent in Figure 4-26, which is an elemental map for silica generated by the electron microprobe. In Figure 4-26 calcite is shown in black and the opaline silica is the (typically) red and white, banded material. The color bar near the upper right hand corner of the figure shows silica levels as a function of color intensity. In this case white is the highest silica concentration and black is the lowest concentration. The color bands on the elemental map reflect fluctuations in the silica content of the botryoidal silica. Examination of the thin section under 


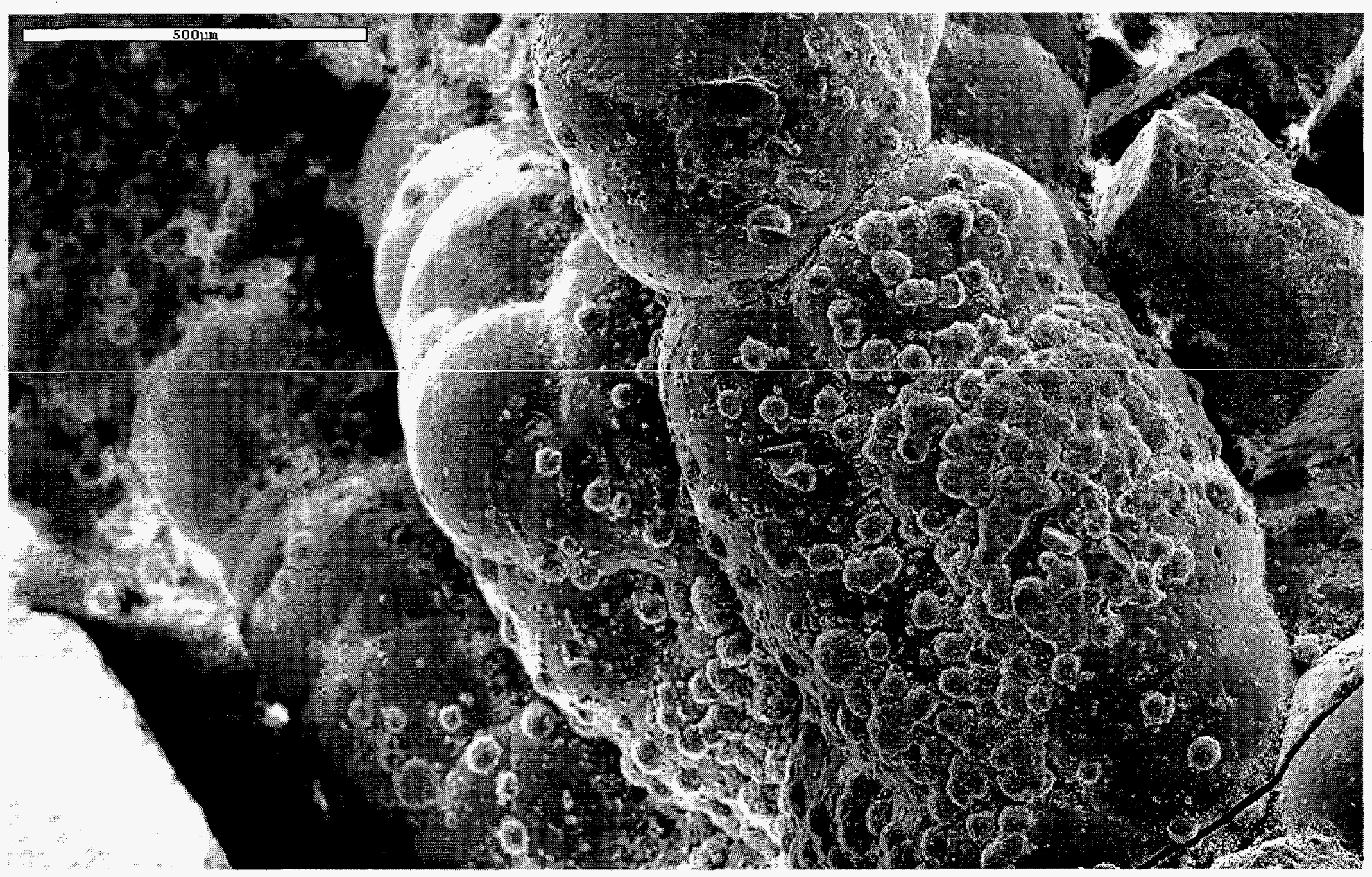

Figure 4-24

SEM Image Showing Botryoidal Opaline Silica (with later opaline overgrowths) and Eroded Calcite from PM-2 (320 foot depth) 


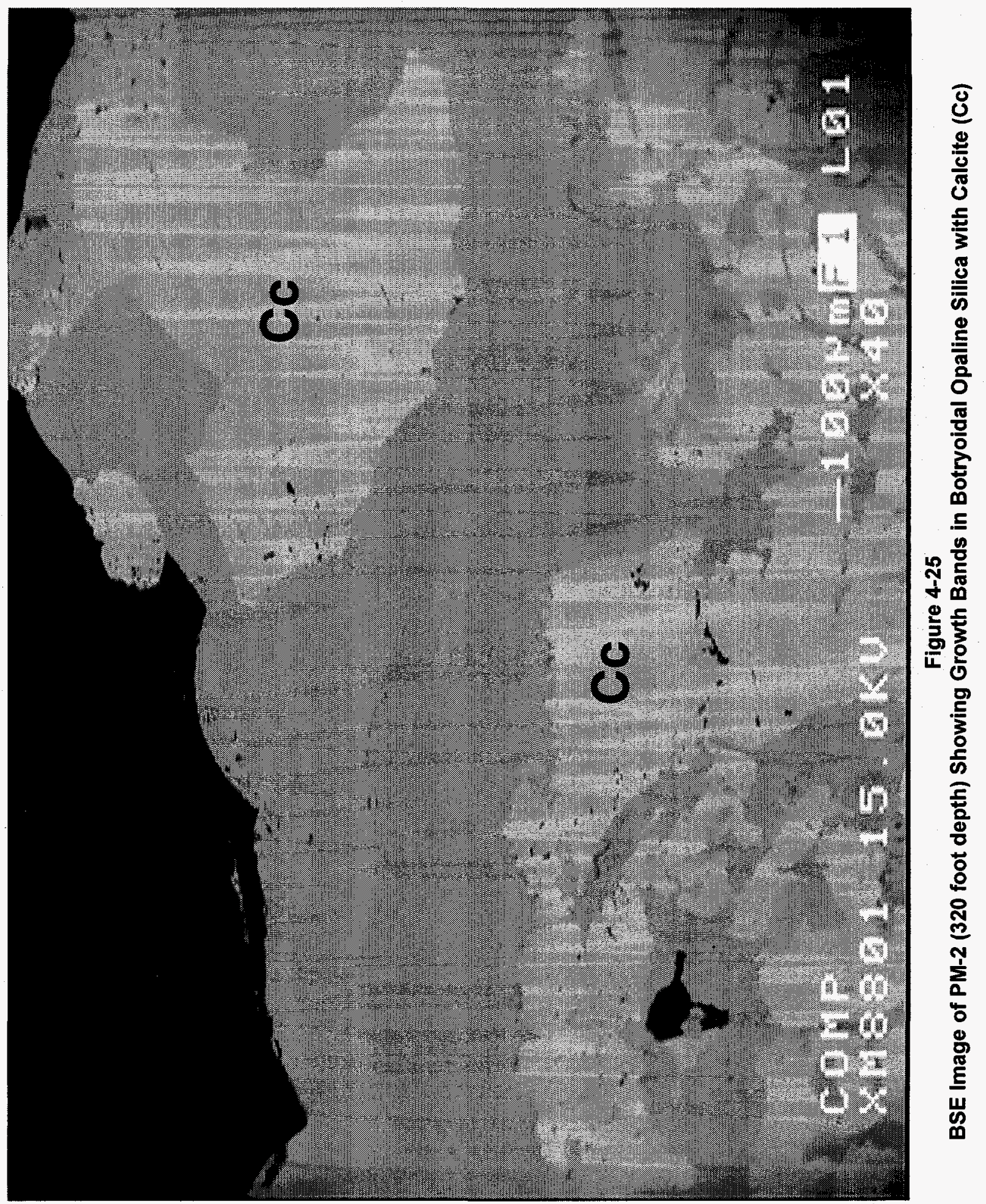




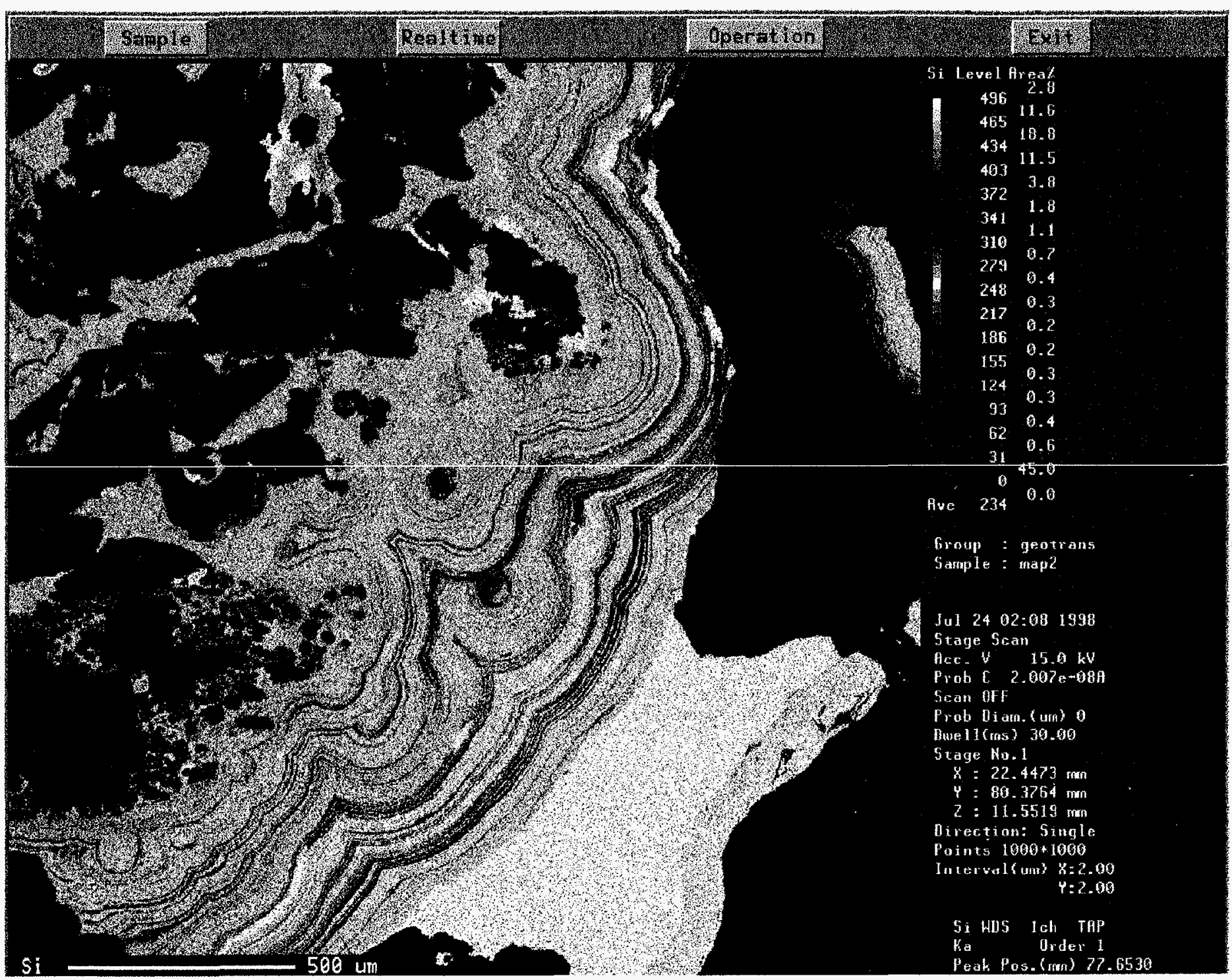

Variations in color due to fluctuating water content (white $=$ lowest water content, yellow $=$ highest water content). The black areas are calcite.

Figure 4-26

Electron Microprobe Elemental Map for Silica in PM-2 (320 foot depth) 
the SEM revealed faint topographic relief in the sample that coincides with the banding shown on the elemental map. Attempts to analyze these bands on the electron microprobe did not result in any quantifiable difference between them, or identify the presence of other included elements. The greater tendency for the low relief bands to etch or pit under the incident electron beam is suggestive that they have a slightly higher water content.

\subsubsection{Sample from 4,180 Feet}

This sample contains a 1-2 millimeter thick vein/filled fracture hosted by the altered porphyritic Dacite of Mt. Helen of the Volcanics of Quartz Mountain, which comprises a lava flow aquifer within the Basal Aquifer. Calcite is present within the fracture filling material as blocky crystals, but the predominant phase on the partially open aperture fracture (Figure 4-27) is euhedral to subhedral intergrown crystals of barite $\left[\mathrm{BaSO}_{4}\right]$, accompanied by quartz. Minor amounts of smectite clay overgrowths are present on quartz. Judging from the widespread occurrence of fractured barite crystals, it appears that the crystals on this fracture have largely bridged the aperture and were broken when the opposing sides separated.

\subsubsection{Sample from 5,893 Feet}

This sample is a highly fractured rhyodacite porphyry of the Volcanics of Quartz Mountain, which comprises a lava flow aquifer within the Basal Aquifer. An open fracture face on the surface of the sample is covered with a white clay-rich selvage comprised of quartz and calcite in a massive mat of mixed illite/smectite. A second veinlet containing calcite, chlorite, hematite and clay intersects the fracture surface. Dolomite $\left[\mathrm{CaMg}\left(\mathrm{CO}_{3}\right)_{2}\right]$, ferroan dolomite $\left[\mathrm{FeMg}\left(\mathrm{CO}_{3}\right)_{2}\right]$, and mixed barite plus celestine $\left[\mathrm{SrSO}_{4}\right]$ are observed in thin section in this second veinlet. No SEM or BSE images were taken of this sample. No electron microprobe point analyses were collected from this sample.

The HRTEM analysis of this sample (Appendix A) indicates the presence of quartz, calcite, dolomite, and mixed illite/smectite clay on the fracture surface.

\subsubsection{Sample from 6,750 Feet}

This is a sample of an altered dacite lava from the Volcanics of Quartz Mountain, comprising a lava flow aquifer within the Basal Aquifer. Sample contains a fracture coated with pinkish colored calcite, anhydrite $\left[\mathrm{CaSO}_{4}\right]$, chlorite, epidote $\left[\mathrm{Ca}_{2}\left(\mathrm{Fe}^{3+}, \mathrm{Al}_{3}\left(\mathrm{SiO}_{4}\right)\left(\mathrm{Si}_{2} \mathrm{O}_{7}\right)\right.\right.$ $\left.(\mathrm{O}, \mathrm{OH})_{2}\right]$, sphene $\left[\mathrm{CaTiSiO}_{5}\right]$, rutile $\left[\mathrm{TiO}_{2}\right]$, and mixed illite/smectite. 


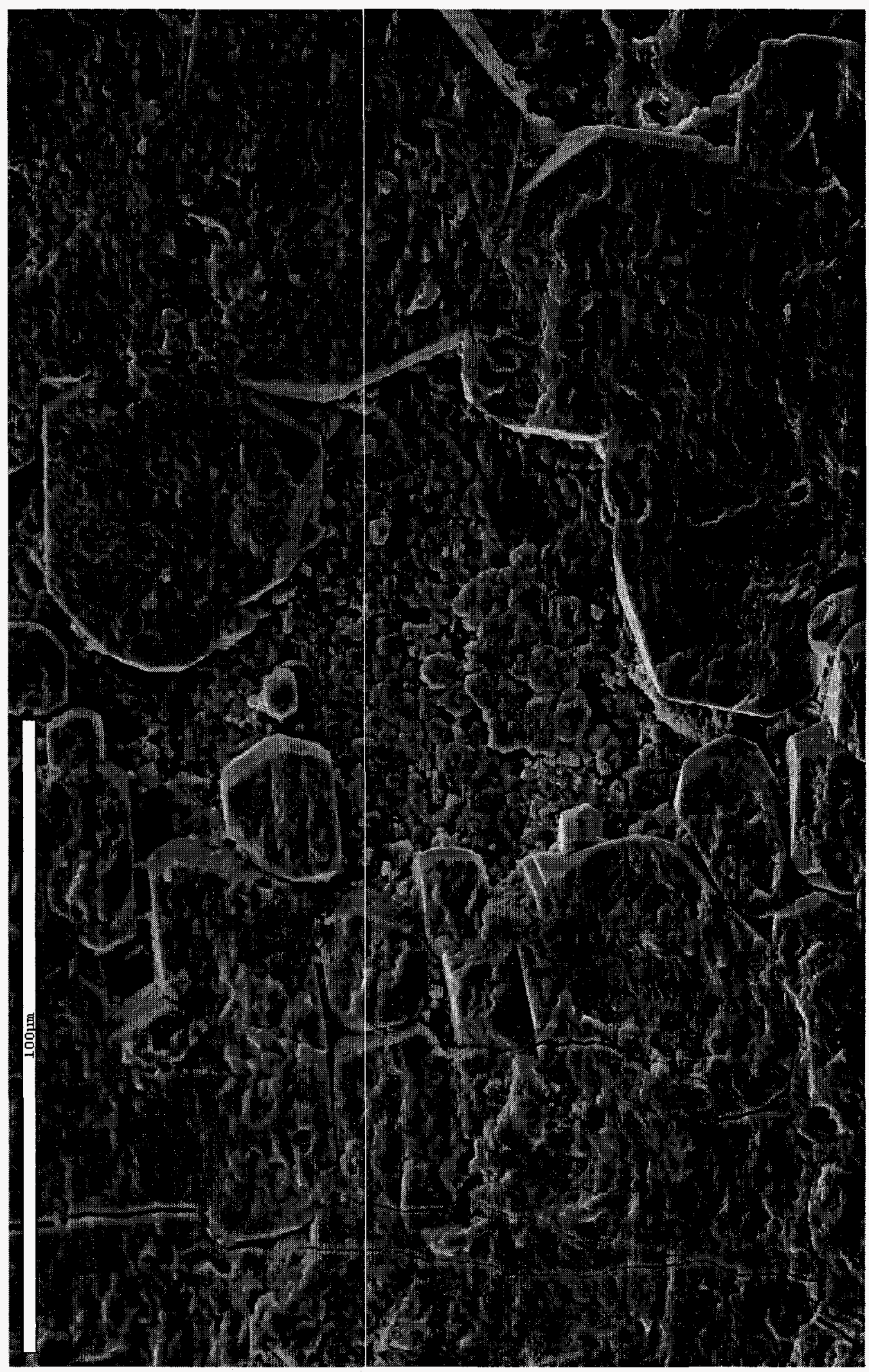

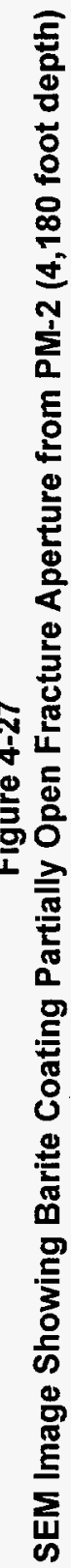


Both potassium feldspar and plagioclase are also present on or near the fracture surface. The potassium feldspar appears to be a hydrothermal alteration phase. The pitted and corroded nature of the plagioclase indicates that it is most likely an altered primary mineral phase. The calcite from this sample is eroded or pitted and locally overgrown with illite/smectite (Figure 4-28) or associated with chlorite (Figure 4-29).

Electron microprobe point analyses for sample epidote, potassium feldspar, and plagioclase are included in Table 4-1.

\subsubsection{Sample from 8,050 Feet}

This is a sample of a carbonate-bearing vein which cuts altered dacite lava from the Volcanics of Quartz Mountain, comprising a lava flow aquifer within the Basal Aquifer. Sample consists of thick (approximately one centimeter) vein material which lacks any exposed growth faces or open aperture. Figure 4-30 is a BSE image showing the predominance of quartz, calcite, and potassium feldspar in the vein material with associated chlorite, epidote, and pyrite. This sample was collected primarily as a source for carbon isotopic data (Rose et al., 1998). Electron microprobe point analyses for chlorite and potassium feldspar are included in Table 4-1.

\subsubsection{Sample from 8,403 Feet}

This is a sample of a brecciated and altered Tertiary granodiorite placed, due to stratigraphic location and to similarities in fracturing and alteration style to the layered volcanics, within the Basal Aquifer. Numerous veinlets are present in this sample which are typified by a quartz, calcite, pyrite, illite/smectite assemblage. Figure 4-31 is a SEM image that shows eroded quartz and calcite which is locally covered with a mixed illite/smectite mat. A close-up image (Figure 4-32) of the eroded quartz crystals also shows the incipient development of illite/smectite coatings. A close-up of the clay mat is shown in Figure 4-33. The coarse, blocky nature of the calcite in this sample is clearly shown in Figure 4-34. Figure 4-35 is a BSE image showing the intergrown relationships between calcite, quartz, and pyrite.

\subsection{Drill Hole PM-3}

PM-3 is an exploratory drill hole placed west of the NTS boundary. This site was chosen for sampling because of its westerly location and because of the calcite identified by Warren et al. (1998). The hole has a total depth of 3,019 feet and only washed cuttings and percussion gun sidewall cores are available. Three samples were collected from this drill hole. One sidewall core sample and cuttings from a 20 foot 


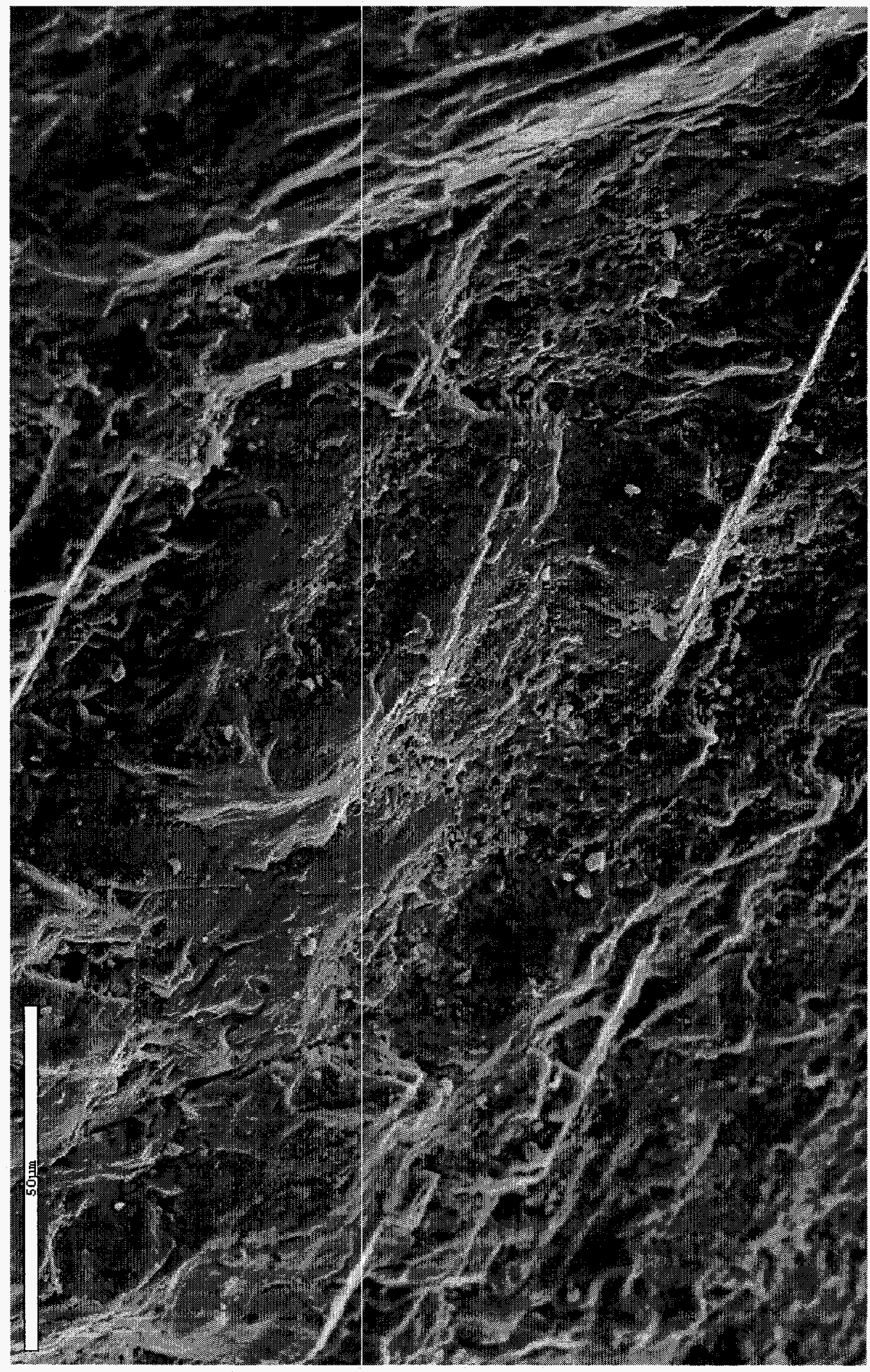

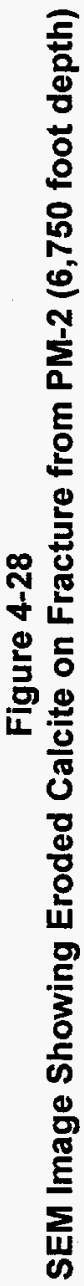




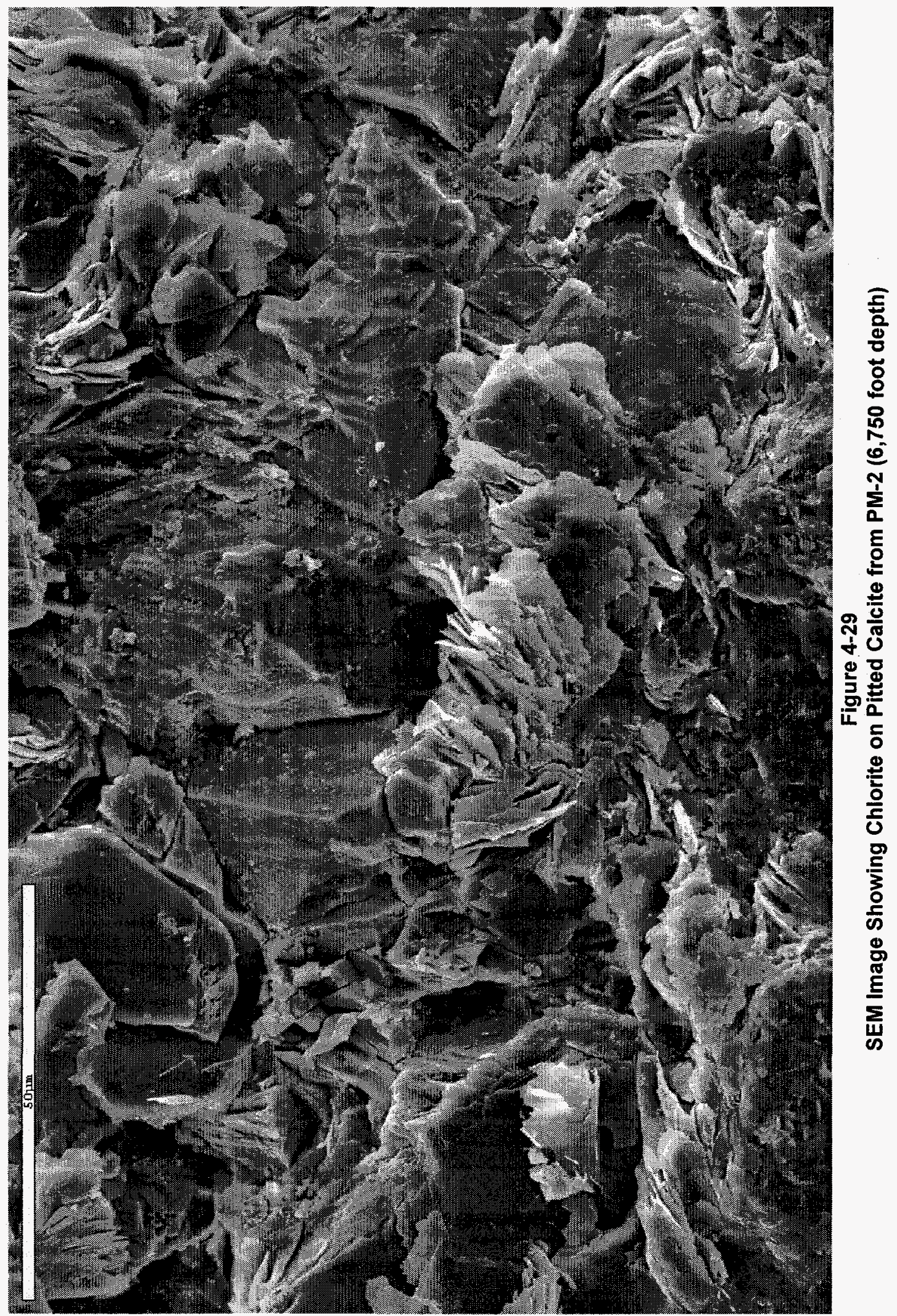




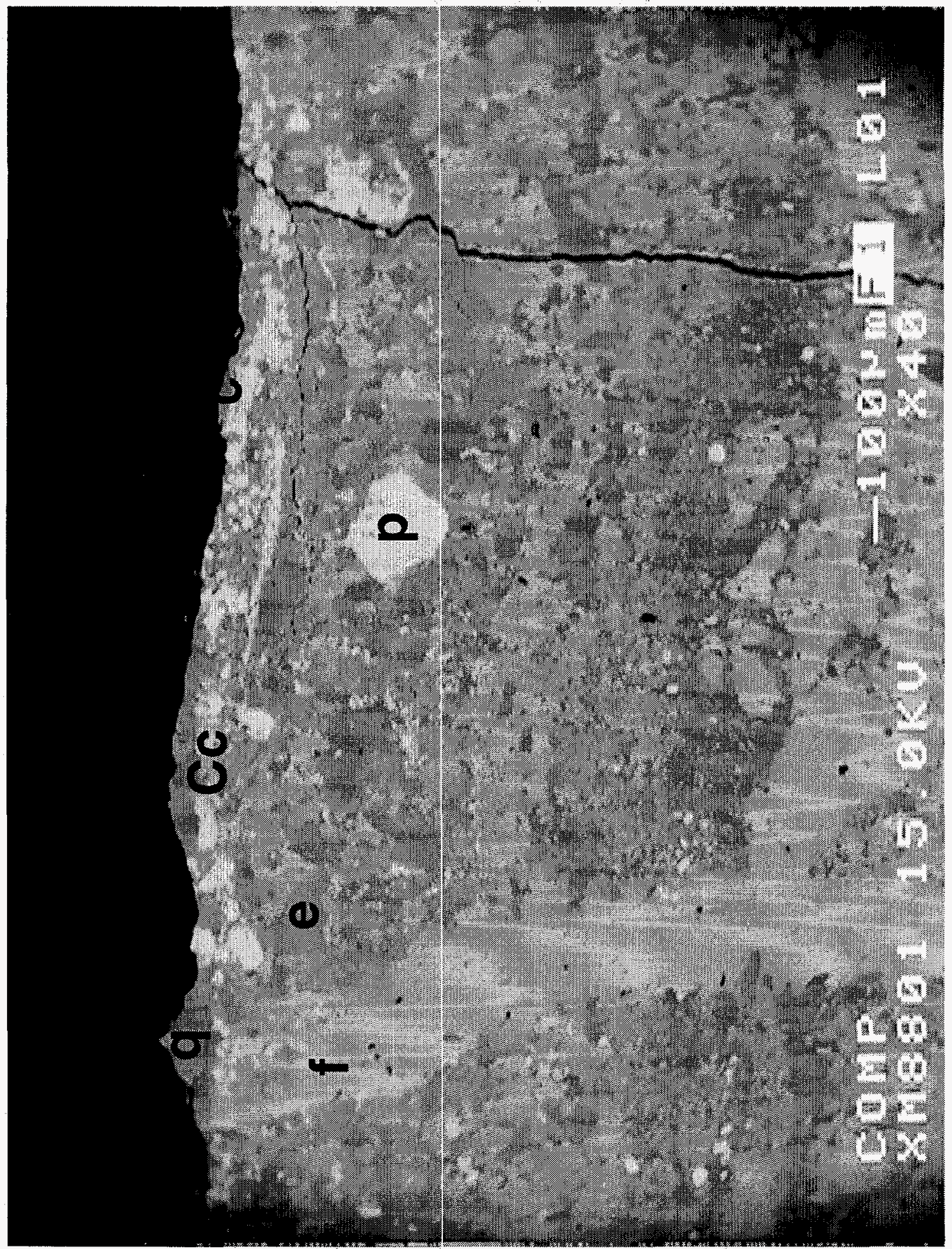

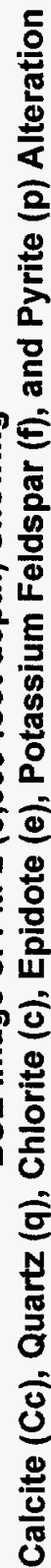




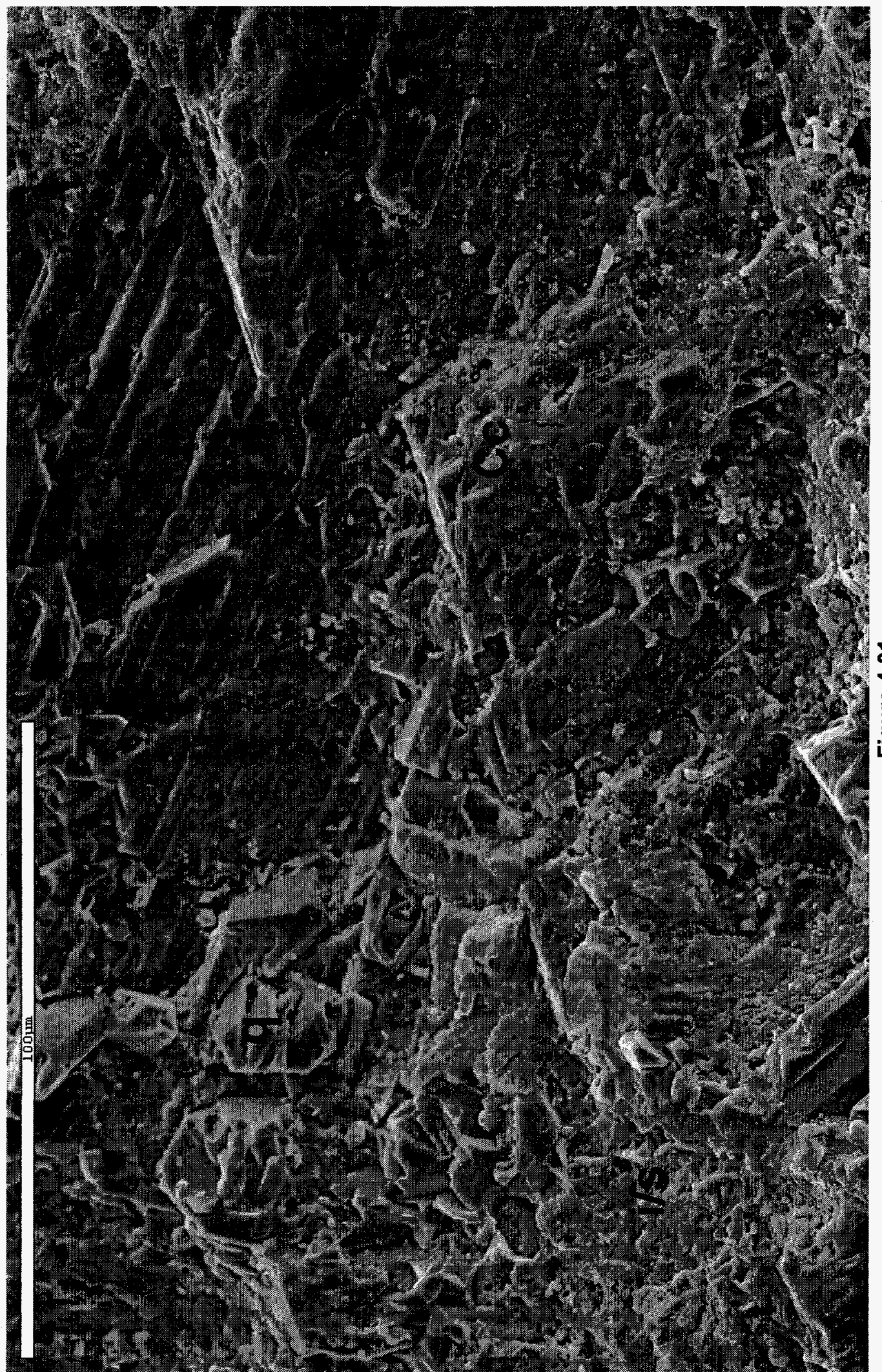

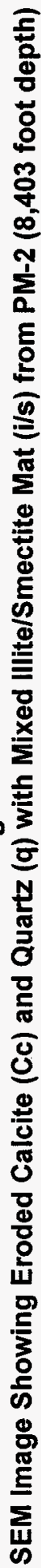




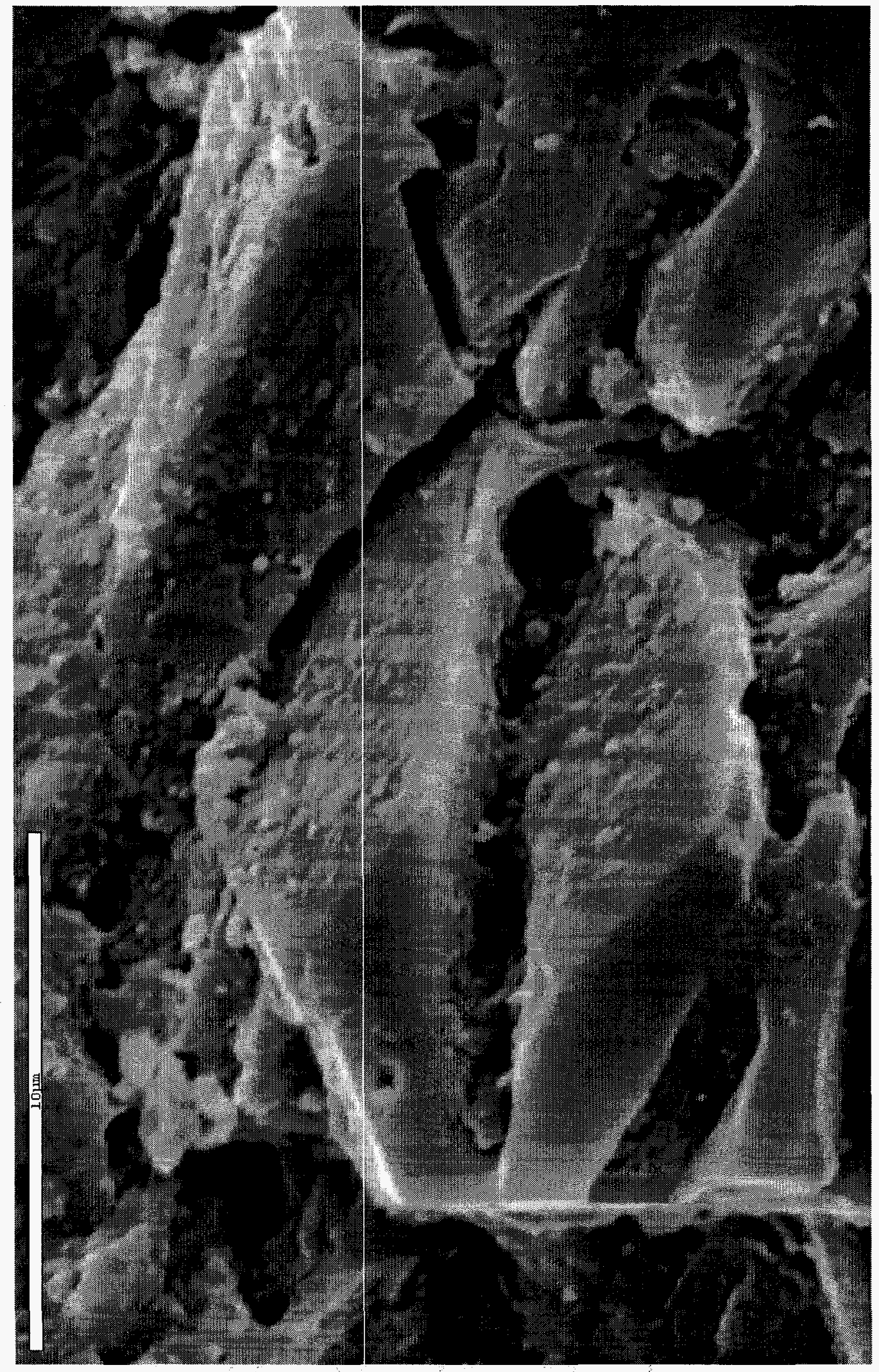




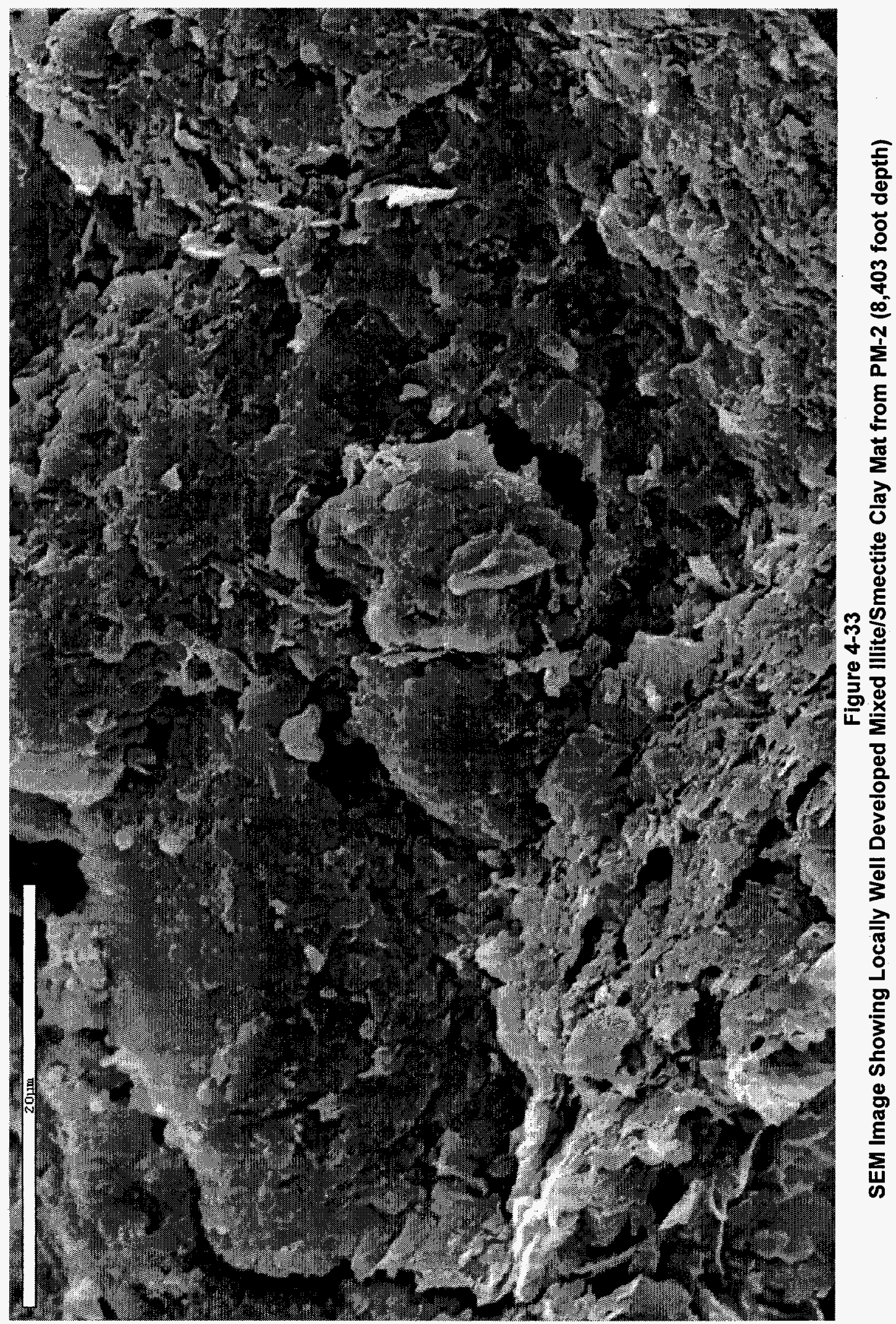




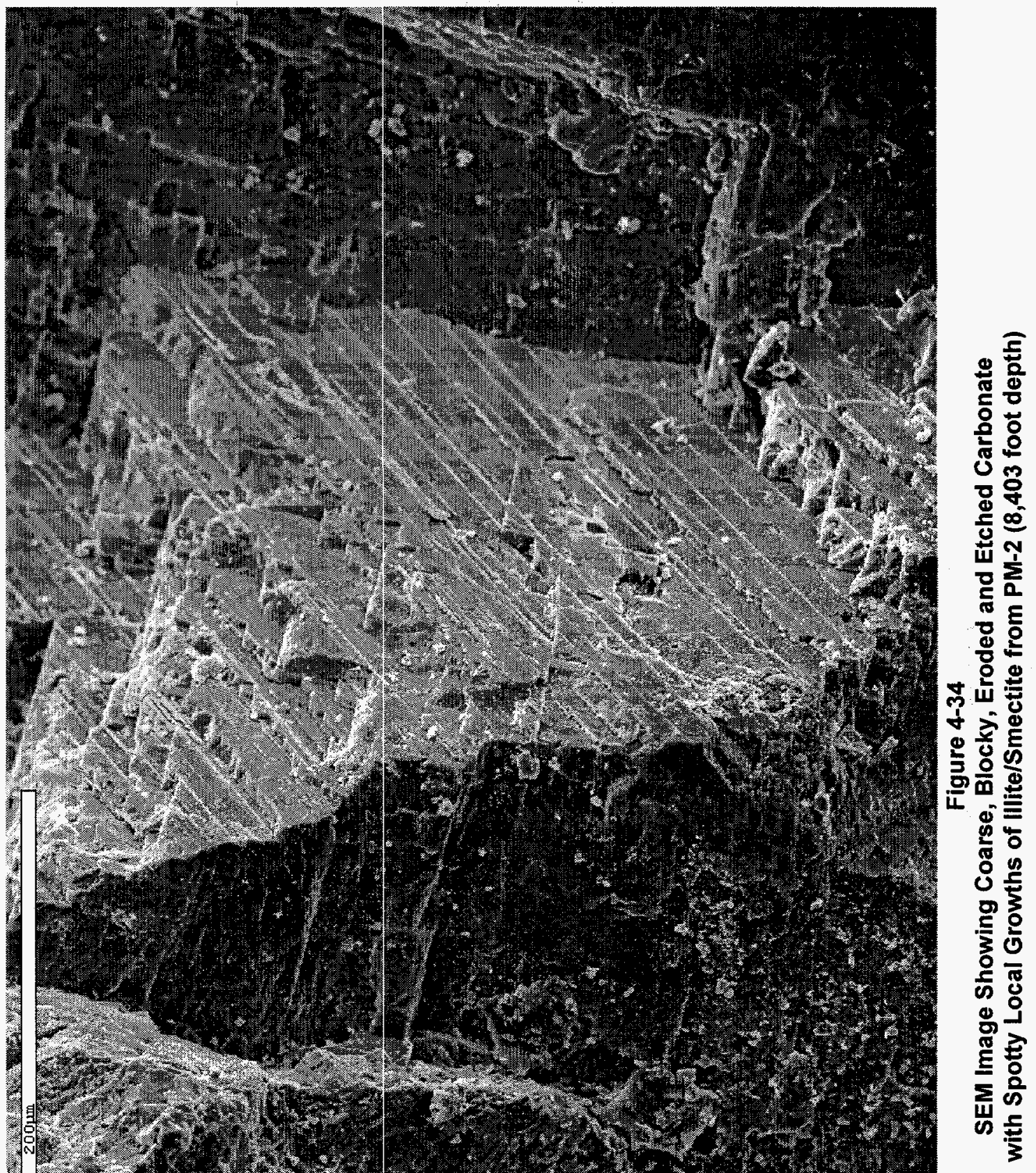


interval were collected of the 'Basalt of U-19ac,' comprising part of the Upper Paintbrush Confining Unit (Figure 4-35). While no preserved fracture coatings were noted in this drill hole, a percussion gun sidewall core was selected from the archived material based on information contained in Warren et al. (1998) that this interval had sufficient carbonate material for isotopic analysis (Rose et al., 1998). The soft, friable nature of the sidewall core sample from this drill hole resulted in severe sample charging during SEM analysis. No SEM images were obtained. Cuttings from a 10 foot interval were also collected of the 'Basaltic lavas of UE-19e' which also comprises part of the Upper Paintbrush Confining Unit. The cuttings samples were collected for isotopic analysis only.

\subsubsection{Sample from 1,750 Feet}

This is a sample of a percussion gun sidewall core of the 'Basalt of U-19ac' comprising part of the Upper Paintbrush Confining Unit. SEM analysis of this sample was affected by strong sample charging under the incident electron beam. The soft, friable consistency of the sample made it a very poor electrical conductor even after repeated efforts to gold coat the sample and electrically ground it to the sample holder. At the scanning times required to obtain a high resolution image, minor sample oscillations would result in blurred or distorted images (similar to that seen in Figures 4-17 and 4-18 from U-19ar, but much more prominent). No SEM images were obtained. Visual SEM analysis of the sample indicated a predominance of smectite with two generations of calcite. Small (<5 microns) euhedral calcite rhombs are locally present in addition to coarser, pitted and eroded calcite.

\subsubsection{Sample from 1,790 to 1,810 Feet}

This is a sample of the basalt of U-19ac, similar to percussion gun sidewall core collected at 1,750 feet. Calcite is present (Rose et al., 1998) as microfracture coatings and vesicle fillings. No micrographic analysis of this sample was conducted.

\subsubsection{Sample from 2,860 to 2,870 Feet}

This is a sample of the basalt of UE-19e. Calcite is present (Rose et al., 1998) as microfracture coatings. No micrographic analysis of this sample was conducted. 


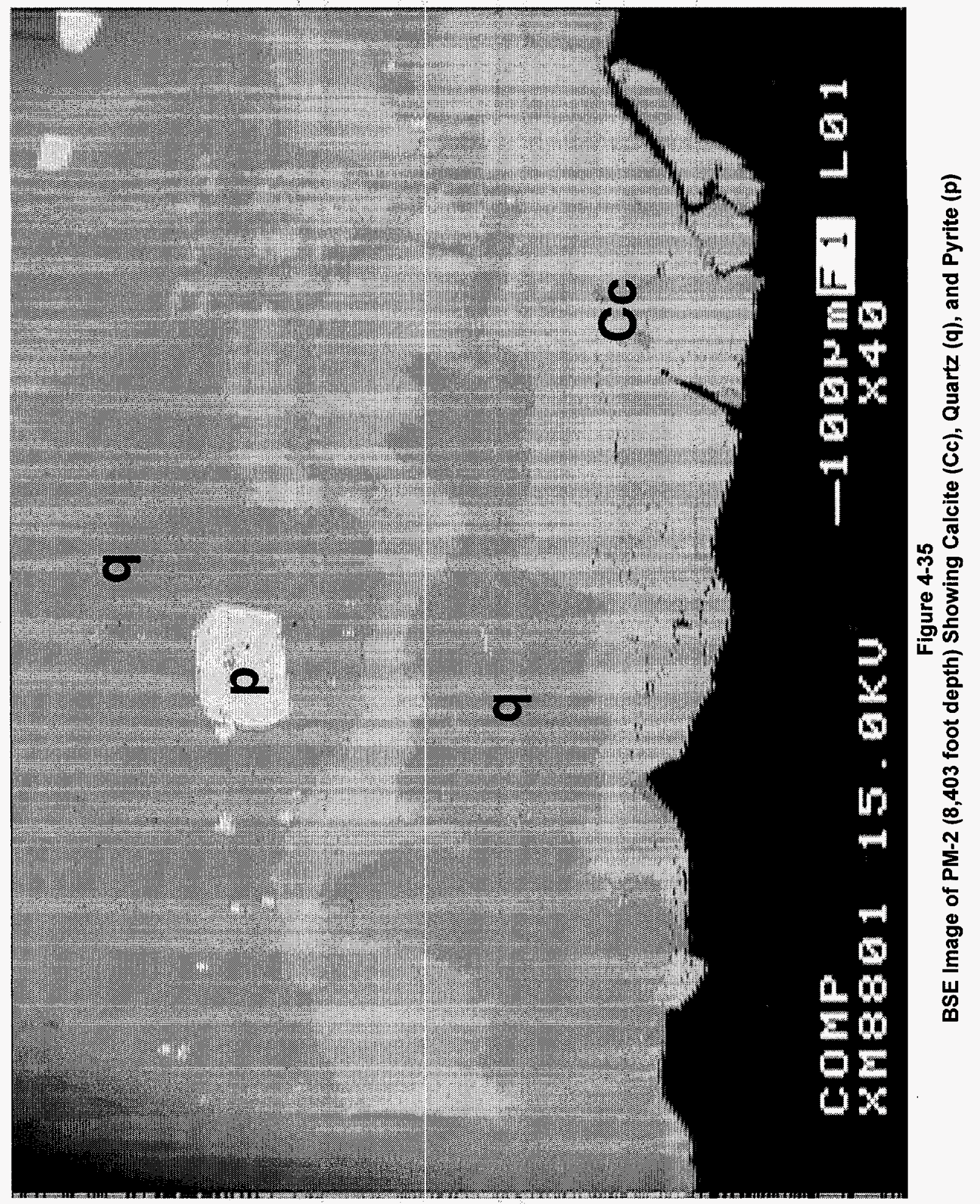




\subsection{Conclusions}

The results of fracture coating phase characterization activities are summarized in Table 5-1. Fourteen core samples with well preserved fracture coating phases were collected from three of the six drill holes selected for evaluation. Six other samples (cuttings and percussion gun sidewall cores) of non-fractured calcite-bearing materials were collected primarily for a carbon isotopic evaluation, which is summarized in a companion report (Rose et al., 1998). Three of the principal volcanic aquifers are represented by the samples collected.

Table 5-1

Summary of Fracture Coating Phase Distribution as a Function of Hydrostratigraphy

\begin{tabular}{|c|c|c|c|}
\hline $\begin{array}{c}\text { Hydrostratigraphic } \\
\text { Unit }\end{array}$ & $\begin{array}{l}\text { Saturated or } \\
\text { Unsaturated }\end{array}$ & $\begin{array}{c}\text { Characteristic } \\
\text { Mineral Assemblage }\end{array}$ & $\begin{array}{c}\text { Specific Examples } \\
\text { (feet) }\end{array}$ \\
\hline \multirow[b]{2}{*}{$\begin{array}{l}\text { Timber Mountain } \\
\text { Aquifer }\end{array}$} & Unsaturated & $\begin{array}{c}\text { Calcite } \\
\text { Illite/smectite } \\
\text { Hydrated silica }\end{array}$ & $\begin{array}{l}\text { U-19ar (173) } \\
\text { PM-2 (320) }\end{array}$ \\
\hline & Saturated & $\begin{array}{c}\text { Calcite } \\
\text { Illite/smectite } \\
\text { Potassium feldspar } \\
\text { Alkali feldspar } \\
\text { Zeolites } \\
\text { Quartz } \\
\text { Fe- and Mn-oxides }\end{array}$ & $\begin{array}{l}\text { UE-18t }(1,378) \\
\text { UE-18t }(1,390.5) \\
\text { UE-18t }(1,399) \\
\text { UE-18t }(2,002) \\
\text { UE-18t }(2,020) \\
\text { UE-18t }(2,583)\end{array}$ \\
\hline $\begin{array}{l}\text { Upper Paintbrush } \\
\text { Confining Unit }\end{array}$ & Saturated & $\begin{array}{l}\text { Calcite } \\
\text { Smectite }\end{array}$ & PM-3 $(1,750)$ \\
\hline Belted Range Aquifer & Saturated & $\begin{array}{l}\text { Fe- and Mn-oxides } \\
\text { Quartz } \\
\text { Calcite } \\
\text { K- and Na-feldspar } \\
\text { Illite/smectite }\end{array}$ & UE-20f $(8,668)$ \\
\hline Basal Aquifer & Saturated & $\begin{array}{c}\text { Quartz } \\
\text { Carbonates (Ca, Mg, } \\
\text { Fe, Mn) } \\
\text { Sulfates (Ca, Ba, Sr) } \\
\text { Pyrite } \\
\text { Chlorite } \\
\text { Epidote } \\
\text { Illite/smectite }\end{array}$ & $\begin{array}{c}\text { UE-20f }(13,674) \\
\text { PM-2 }(4,180) \\
\text { PM-2 }(5,893) \\
\text { PM-2 }(6,750) \\
\text { PM-2 }(8,050) \\
\text { PM-2 }(8,403)\end{array}$ \\
\hline
\end{tabular}

Eight samples representing the Timber Mountain Aquifer were collected from three different drill holes. Two of these samples come from the unsaturated zone (one being a non-fractured percussion gun sidewall core) and six samples come from a single drill hole in the saturated zone. From these limited samples, fracture coating phases 
within the Timber Mountain Aquifer system can be characterized by calcite + mixed illite/smectite + opaline silica in the unsaturated zone and by calcite + mixed illite/smectite + quartz + feldspars + zeolites + $\mathrm{Fe}$ - and Mn-oxyhydroxides in the saturated zone.

A single sample was collected from the saturated portion of the Belted Range Aquifer. This sample is characterized by intense fracturing and the predominance of $\mathrm{Fe}$ - and $\mathrm{Mn}$-oxyhydroxides with subordinate calcite + quartz + feldspars + mixed illite/smectite. This sample is important because of the intense fracturing and abundance of secondary oxide phases at considerable depth (over 8,600 feet bgs), which suggests the presence of a significantly transmissive hydrogeologic feature or interval. The predominance of secondary oxide phases is also important because of their affinity for the adsorption of dissolved solutes. Because of the limited number of drill holes evaluated and sampled, and the lack of continuous cores from UE-20f, is not possible at this time to determine if this is representative of the Belted Rajnge Aquifer.

Six samples representing the saturated portion of the Basal Aquifer were collected from two different drill holes. Fracture coating phases within the Basal Aquifer are characterized by carbonate minerals (of $\mathrm{Ca}, \mathrm{Mg}, \mathrm{Fe}$, and $\mathrm{Mn}$ ) + quartz + sulfate minerals (of $\mathrm{Ca}, \mathrm{Ba}$, and $\mathrm{Sr}$ ) + pyrite + chlorite + epidote + mixed illite/șmectite + local Fe-oxides. The style and occurrence of these phases is more indicative of an active hydrothermal environment rather than precipitation from a groundwater system. It is entirely plausible that the deeper sections of the volcanic stratigraphy (i.e., the Basal Aquifer) in the Pahute Mesa area will have been affected by the recurrent volcanic activity focused in this general area and show signs of hydrothermal activity.

The SEM analyses of calcite present in these samples reveal textures that indicate the dissolution of calcite is widespread. The presence of multiple generations of calcite and other carbonate minerals suggests that these aquifer systems are at or near equilibrium with respect to carbonate. This should be reflected in the water chemistry in these aquifers and will be evaluated during the speciation calculations conducted as part of the geochemical modeling conducted during FY 1999.

Electron microprobe analysis of relatively soluble phases (such as feldspars) can also be used to constrain equilibrium between fracture surface phases and groundwater. No analyses of volcanic glass were obtained from this group of samples. This is not surprising given the focus of this work on altered, weathered fracture surfaces which would be an unlikely place to preserve glass. Glass analyses from equivalent lithostratigraphic materials will be obtained as necessary from Warren et al. (1998) to support geochemical modeling to be conducted during FY 1999. 
The SEM, electron microprobe, and HRTEM analyses have identified specific zeolite, $\mathrm{Fe}$ - and Mn-oxyhydroxide, and clay minerals in these samples. These minerals are significant because of their potential to adsorb dissolved constituents from through-going groundwater. The potential influence of these specific phases will be evaluated in subsequent solute transport modeling that will be conducted during FY 1999. 
This Page Intentionally Left Blank 


\subsection{References}

Byers, F.M., Jr., W.L. Hawkins, and D.C. Muller. 1981. Geology of Drill Hole UE-18t and Area 18, Timber Mountain Caldera Moat, Nevada Test Site. U.S. Geological Survey Report USGS-474-312. Springfield, VA.

Carroll, R.D. 1966. Preliminary Interpretation of Geophysical Logs, UE-20f, Pahute Mesa, Nevada Test Site. U.S. Geological Survey Technical Letter, Special Studies I-37, Supplement 1. Denver, CO.

Deer, W.A., R.A. Howie, and J. Zussman. 1992. An Introduction to the Rock-Forming Minerals. Longman Scientific and Technical Publishers. Essex, England.

DOE/NV, see U.S. Department of Energy.

Drellack, S.L., Jr., L.B. Prothro, K.E. Roberson, B.A. Schier, and E.H. Price. 1997. Analysis of Fractures in Volcanic Cores from Pahute Mesa, Nevada Test Site. DOE/NV/11718-160, UC-703. Las Vegas, NV: Bechtel Nevada.

Laczniak, R.J., J.C. Cole, D.A. Sawyer, and D.A. Trudeau. 1996. Summary of Hydrogeologic Controls on Ground-Water Flow at the Nevada Test Site, Nye County, Nevada.

U.S. Resources Investigations Report 96-4109. Denver, CO.

Prothro, L.B., and S.L. Drellack, Jr. 1997. Nature and Extent of Lava-Flow Aquifers Beneath Pahute Mesa, Nevada Test Site. DOE/NV/11718-156. Las Vegas, NV: Bechtel Nevada.

Prothro, L.B., M.J. Townsend, S.L. Drellack, Jr., and J.L. Gonzales. 1997. Processing and Geological Analysis of Conventional Cores from Well ER-20-6\#1, Nevada Test Site. DOE/NV/11718-162, UC-703. Las Vegas, Nevada: Bechtel Nevada.

Rose, T.P., F.C. Benedict, Jr., and G.F. Eaton. 1998. Stable Isotope and Radiocarbon Compositions of Secondary Calcite from Pahute Mesa, Nevada Test Site. Livermore, CA: Lawrence Livermore National Laboratory.

U.S. Department of Energy. 1997. Regional Groundwater and Tritium Transport Monitoring and Risk Assessment of the Underground Test Area, Nevada Test Site, Nevada, U.S. Department of Energy, Nevada Operations Office, Environmental Restoration Division, DOE/NV-477, Las Vegas, NV. 
Warren, R.G., D.A. Sawyer, F.M. Byers, eIr., and G.L. Cole. 1998 in preparation. $A$ Petrographic/Geochemical Database and Structural Framework for the Southwestern Nevada Volcanic Field. Los Alamos, NM: Los Alamos National Laboratory.

$\mathrm{Xu}, \mathrm{H}$. 1998. HRTEM Study of Coating Minerals of Fe-Mn Oxides and Clays. Summary report on contract analytical work conducted by the University of New Mexico, Albuquerque, NM. 


\section{Appendix A}

\section{HRTEM Study of Coating Materials of Fe-Mn Oxides and Clays}

(Reproduced as received from author) 


\title{
HRTEM Study of Coating Minerals of Fe-Mn Oxides and Clays
}

\author{
Huifang $X \mathbf{u}$
}

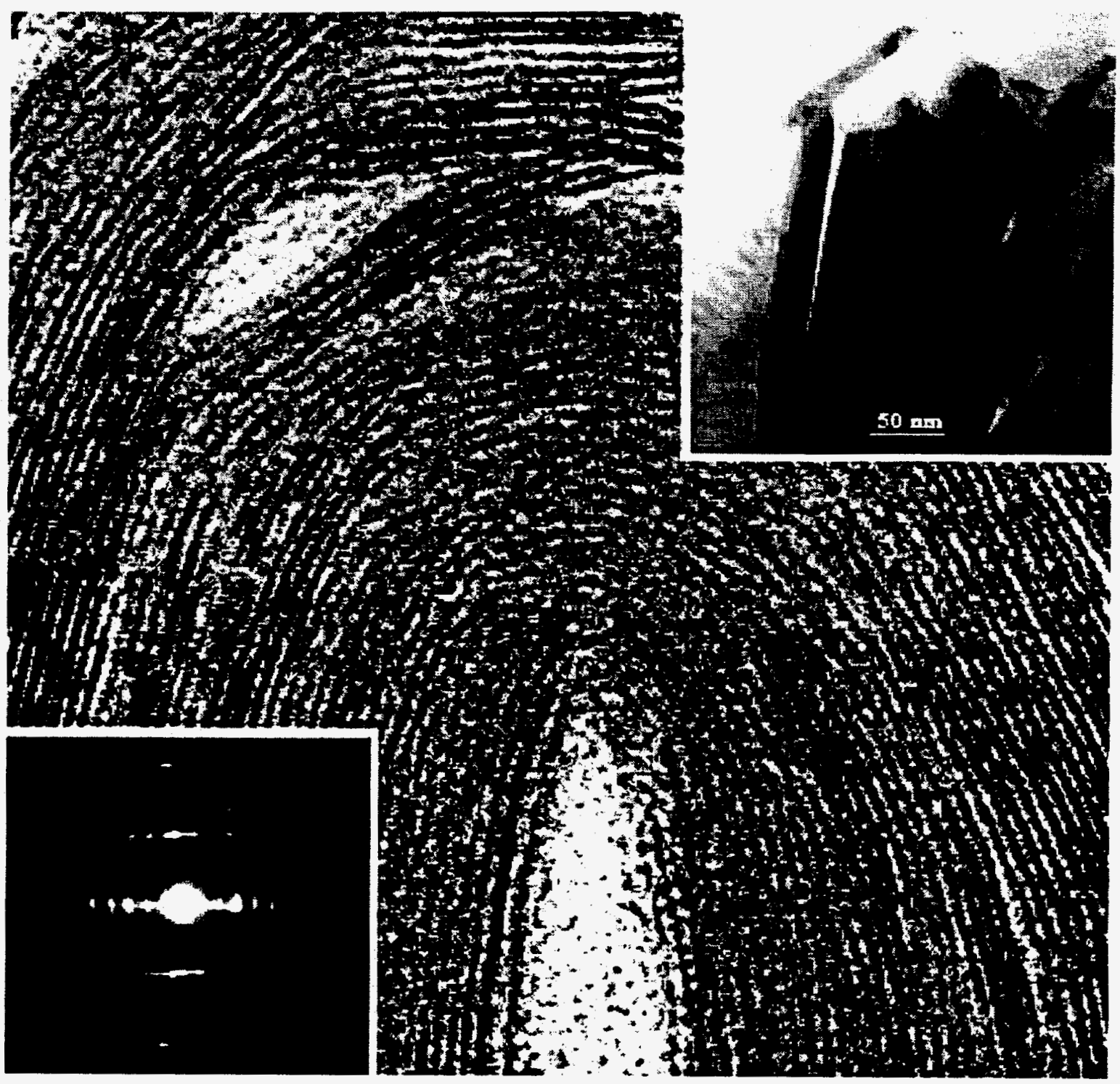

The University of New Mexico

Albuquerque, New Mexico 87131

August, 1998 


\section{TABLE OF CONTENTS}

INTRODUCTION

SAMPLES AND EXPERIMENTS

RESULTS AND DISCUSSION

Sample UE-18T/2020'

Sample UE-20F/8668'

14

Sample UE-20F/13674'

31

Sample PM-2/5893'

37

LITERATURE CITED

45

TABLES

46

APPENDIXES

48 


\section{INTRODUCTION}

The study of poorly-crystalline $\mathrm{Fe}$ and $\mathrm{Mn}$ oxides and clays can provide information about aqueous geochemistry of pore fluids (Groffman et al., 1995; Voigh et al., 1997). Transmission electron microscopy (TEM) and associated techniques can provide information about microstructure and microchemistry of the fine-grained and poorly crystalline Fe-Mn oxides and clays.

In a transmission electron microscope, the high-energy electrons that have been elastically scattered by the specimen may be used for imaging and diffraction from specific areas of the specimen. This provides important structural information about the specimen. The high spatial resolution offered by high-resolution transmission electron microscopy (HRTEM) has been used for studying structures and microstructures (or, textures) at the atomic scale (Wenk, 1976; Buseck and Veblen, 1988; Veblen, 1993). The incident high-energy electrons also undergo inelastic interaction with the specimen that can provide further information about chemistry of the specimen (Spence, 1988). This has given rise to analytical electron microscopy (AEM) of X-ray energy-dispersive spectroscopy (EDS) that can provide valuable information about the specimen chemistry (Spence, 1988).

This report provide phase identification, microstructures, and crystallinity of FeMn oxides / hydroxides, clays, and other related minerals. The crystal size and morphology of these fine grain particles are also reported. Because no zeolite minerals 
were identified during the TEM investigation, this report only describes the coating minerals of Fe-Mn oxides / hydroxides, clays , and other coexisting minerals.

\section{SAMPLES AND EXPERIMENTS}

The fracture coating samples for TEM investigation were from core samples of UE18T/2020', UE-20F/8668', UE-20F/13674', and PM-2/5893'. All the samples were located at the position below static water level (SWL). Both ion milled specimen from the thin sections and powder samples of the fracture coating materials were used for the TEM investigation. Preparation of the ion-milled and powder TEM samples follows the procedures of $\mathrm{Xu}$ and Veblen (1996a, 1996b). All the TEM, HRTEM, and EDS results were carried out by using a JEOL 2010 high-resolution TEM arid associated Link ISIS EDS system with an ultra-thin window for the detector. Diameter of the electron beam spot for collecting EDS spectra ranges from $15 \mathrm{~nm}$ to $30 \mathrm{~nm}$. The HRTEM has point-to-point resolution of $1.94 \AA$. All TEM images and sleeted area electron diffraction (SAED) patterns were digitally recorded using a slow-scan CCD camera.

$X$-ray powder diffraction pattern were obtained by using a Sintag Pad V automated powder diffraction unit. Materials Data, Inc. Jade software for data reduction and analysis. 


\section{RESULTS AND DISCUSSION}

\section{Sample UE-18T/2020'}

This sample shows orange-yellowish coating layer. X-ray powder diffraction shows the coating layer contains calcite, illite, and quartz (Appendix 1). Figure 1-1 shows calcite (cc), quartz, and aggregate of an Fe-rich phase (akaganeite). HRTEM image shows lattice fringes and low angle boundary between neighboring akaganeite plates (Figure 1-2). SAED pattern indicates that the Fe-rich phase is akaganeite $\gamma$ $\mathrm{FeOOH}$ that has hollandite structure (Figure 1-3). EDS spectra from the akaganeite show small amount of $\mathrm{Ca}$ in the crystal (Figure 1-4). It is proposed that $\mathrm{Ca}$ is in the tunnel of the akaganeite structure. Figure 1-5 is a TEM image that shows smectite and coexisting calcite. Figure 1-6 and Figure 1-7 are HRTEM images of the smectite showing curving, bending, and termination of smectite layers. Composition of the smectite are listed in the Table 1 based on EDS analyses. All $\mathrm{Fe}$ are assumed to be ferrous $\mathrm{Fe}^{2+}$ although they are in the form of ferric $\mathrm{Fe}^{3+}$. EDS spectra from the smectite and $\mathrm{Mn}$-bearing calcite are also illustrated in Figure 1-8 and Figure 1-9. 


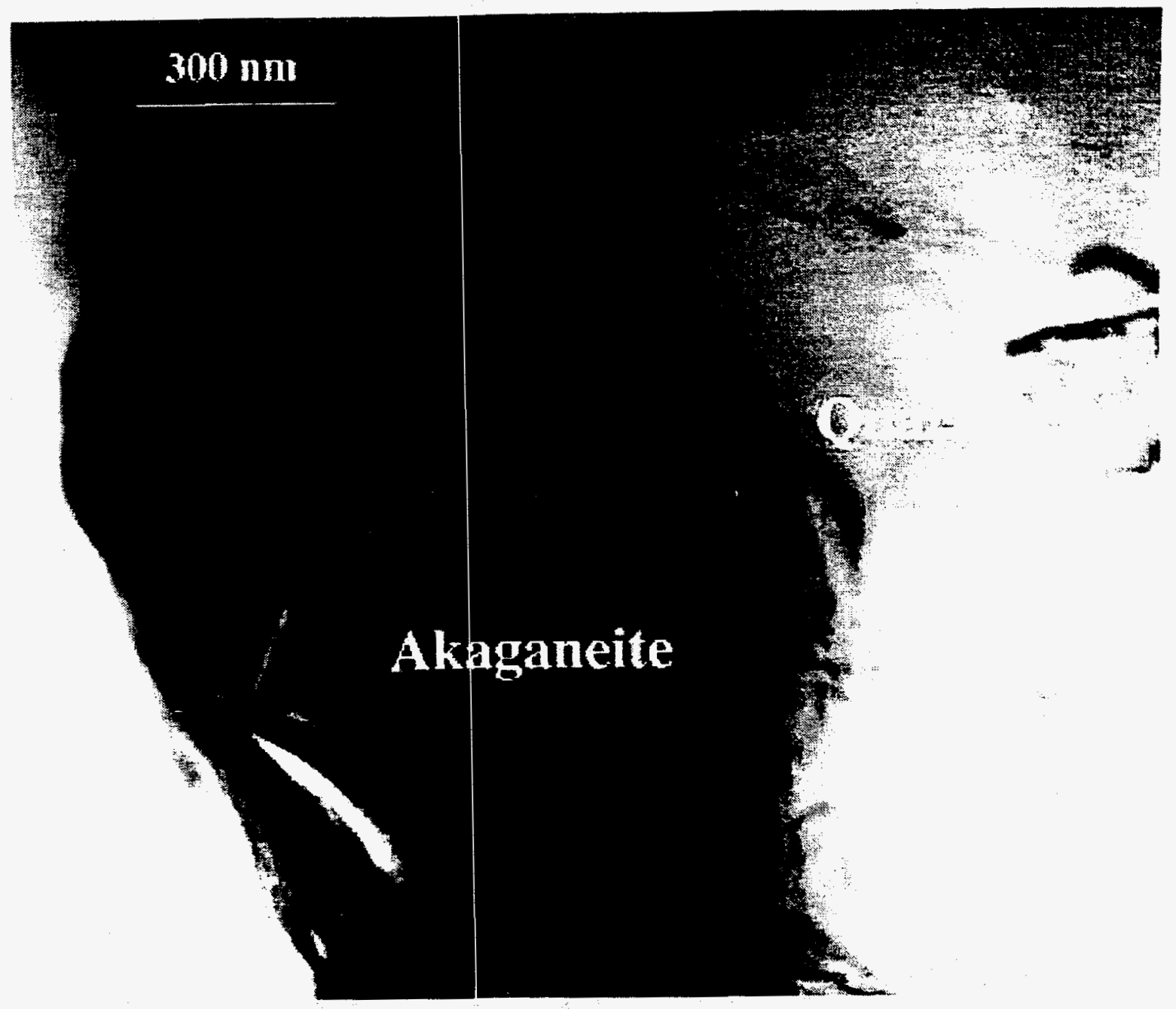

Figure 1-1: TEM image showing akaganeite $(\gamma-\mathrm{FeOOH})$ aggregates and coexisting $\mathrm{Mn}$ bearing calcite and quartz. 


\section{$20 \mathrm{~nm}$}

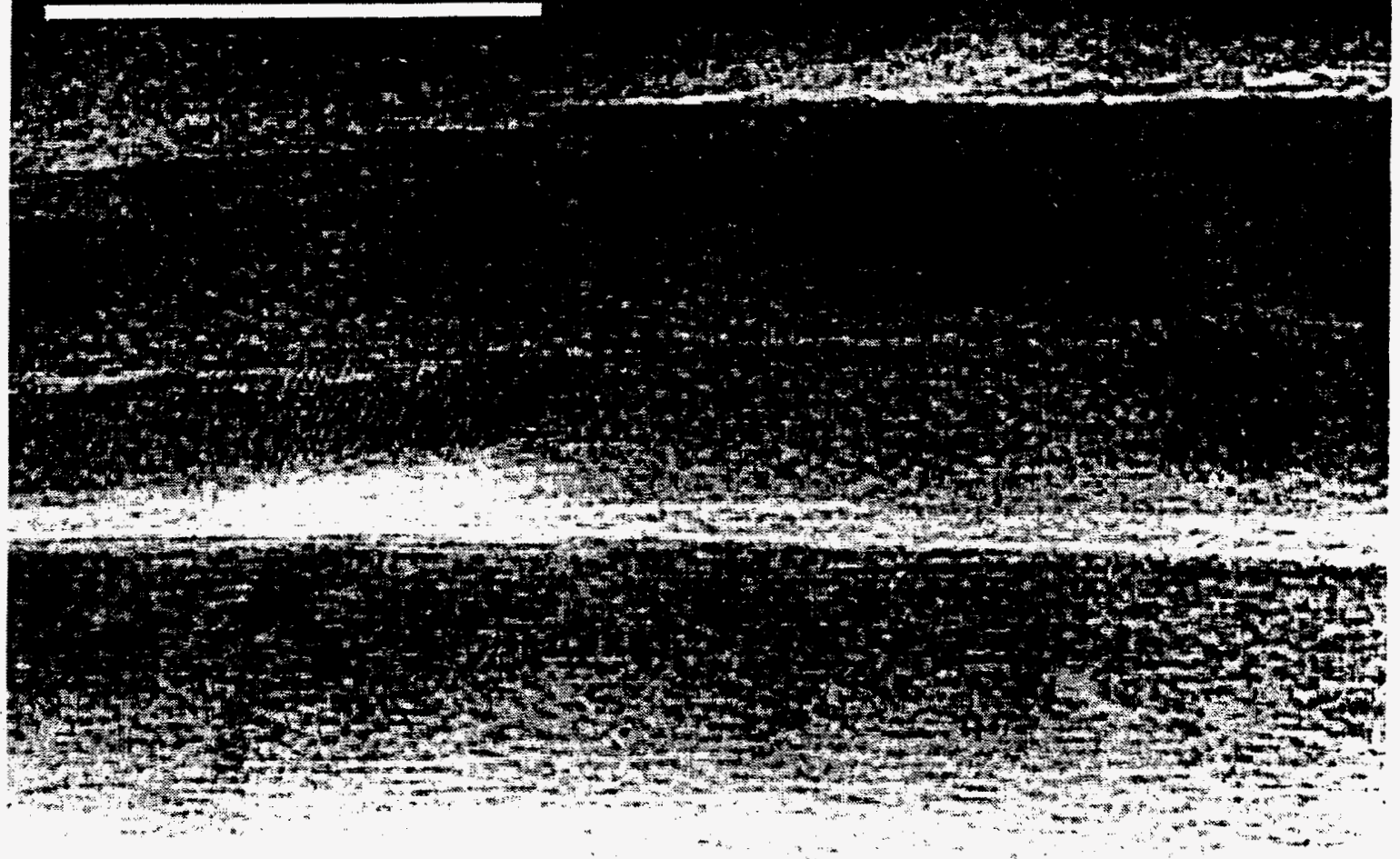

Figure 1-2: HRTEM image shows lattice fringes and low angle boundary between neighboring akaganeite crystals. 


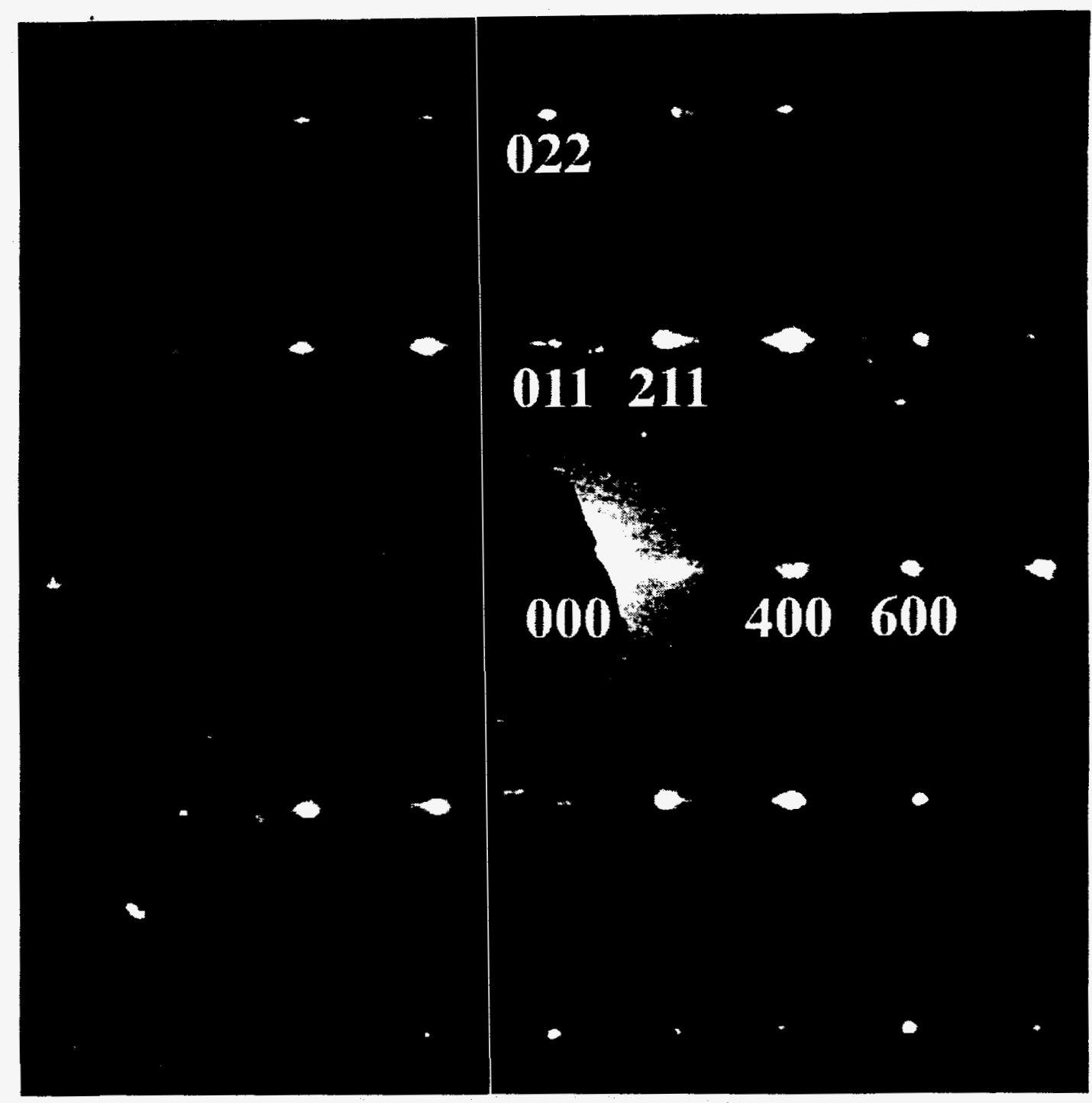

Figure 1-3: SAED pattern of the akaganeite $\gamma-\mathrm{FeOOH}$. 


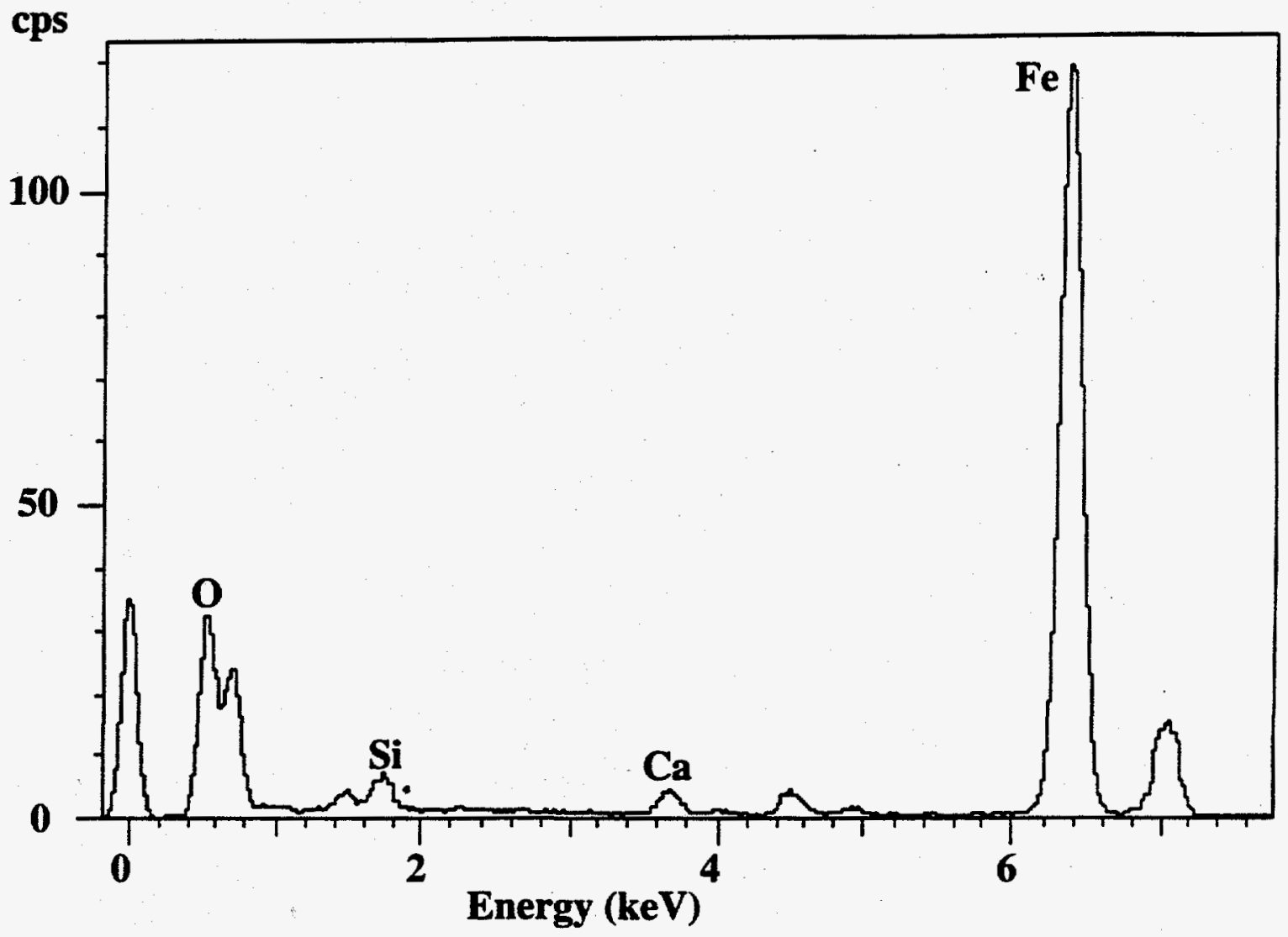

Figure 1-4: EDS spectrum from the akaganeite nearby quartz crystal. 


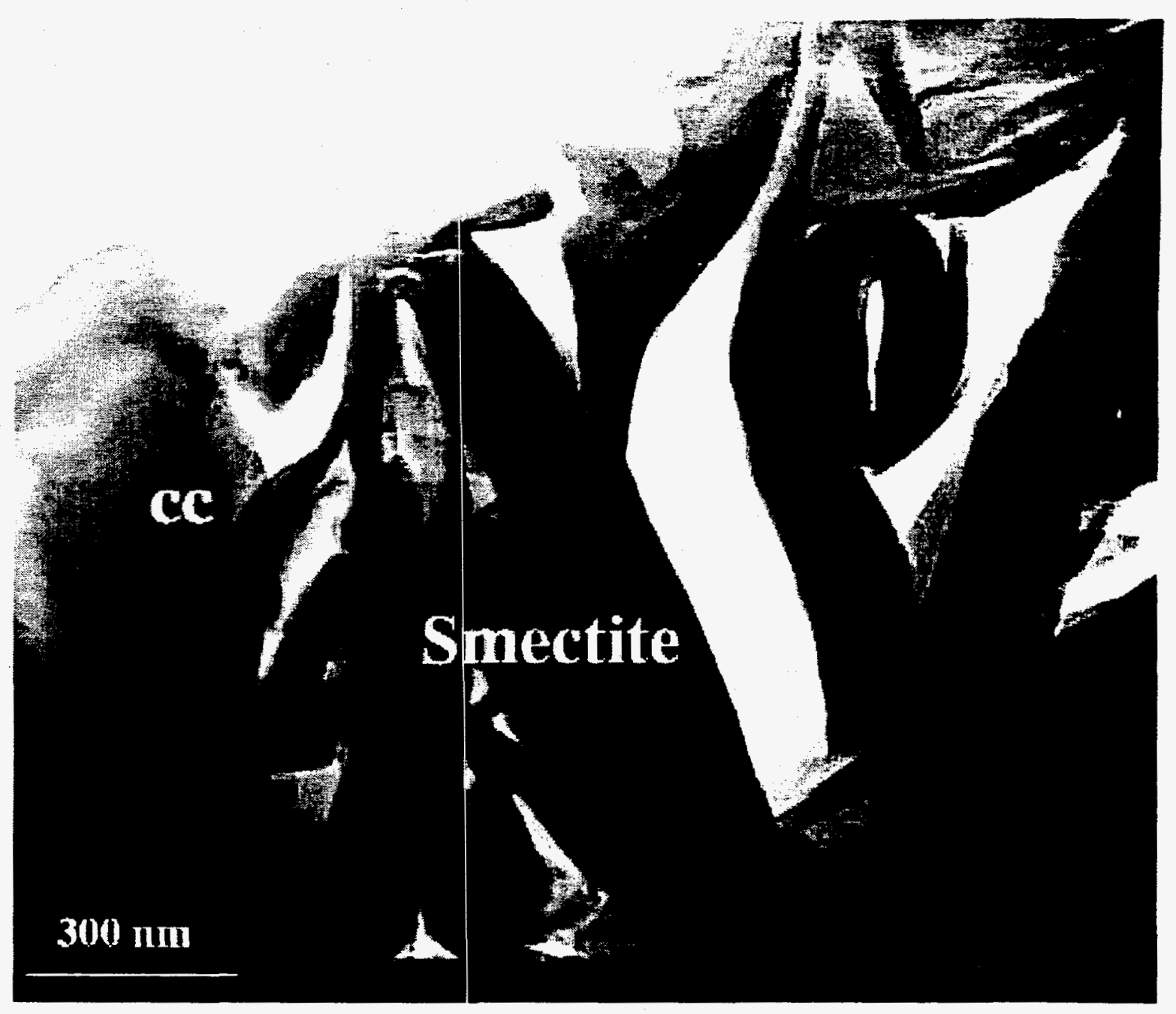

Figure 1-5: TEM image showing smectite and calcite. 


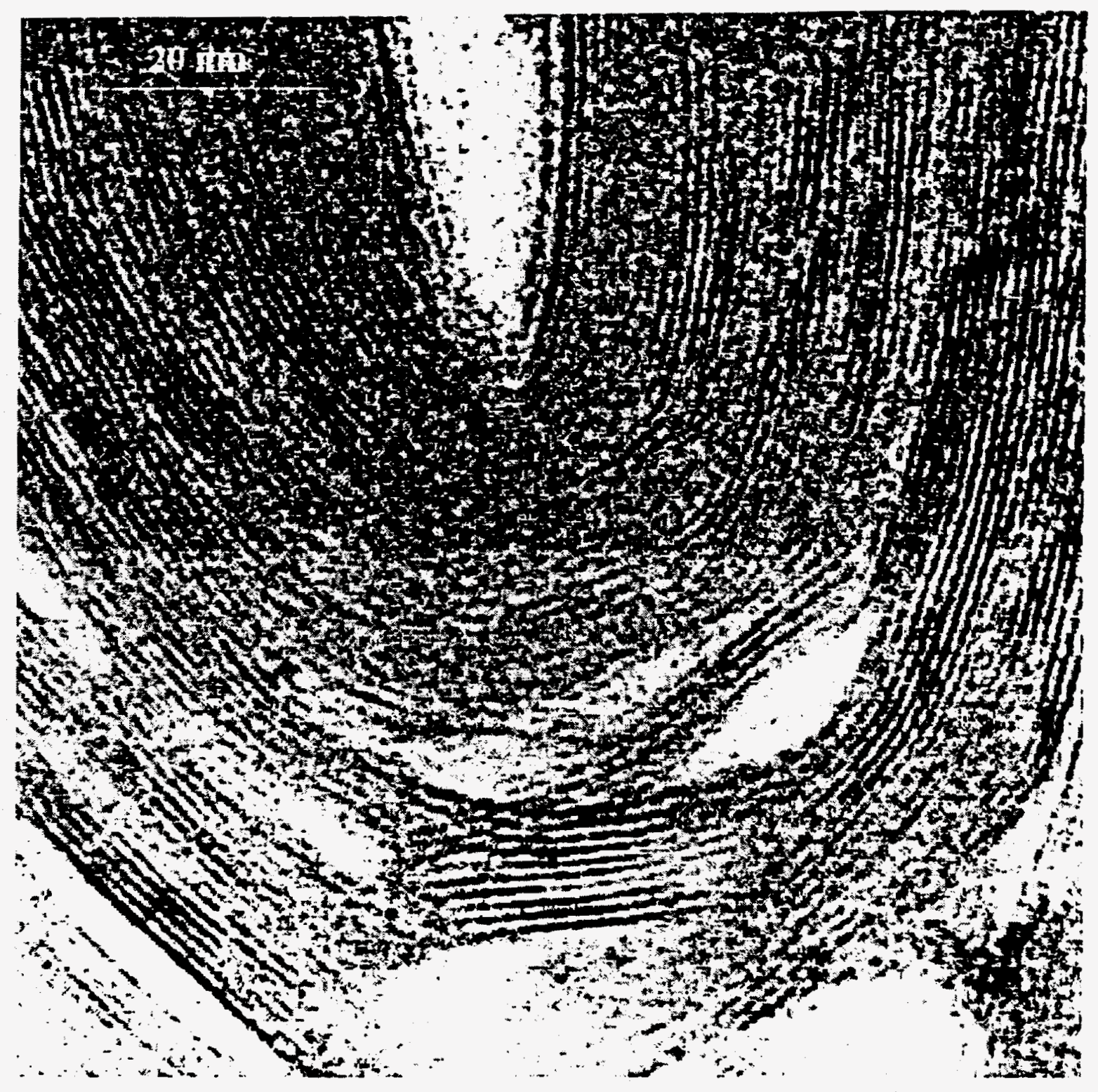

Figure 1-6: HRTEM image of the smectite showing curving, bending, and termination of smectite layers. 


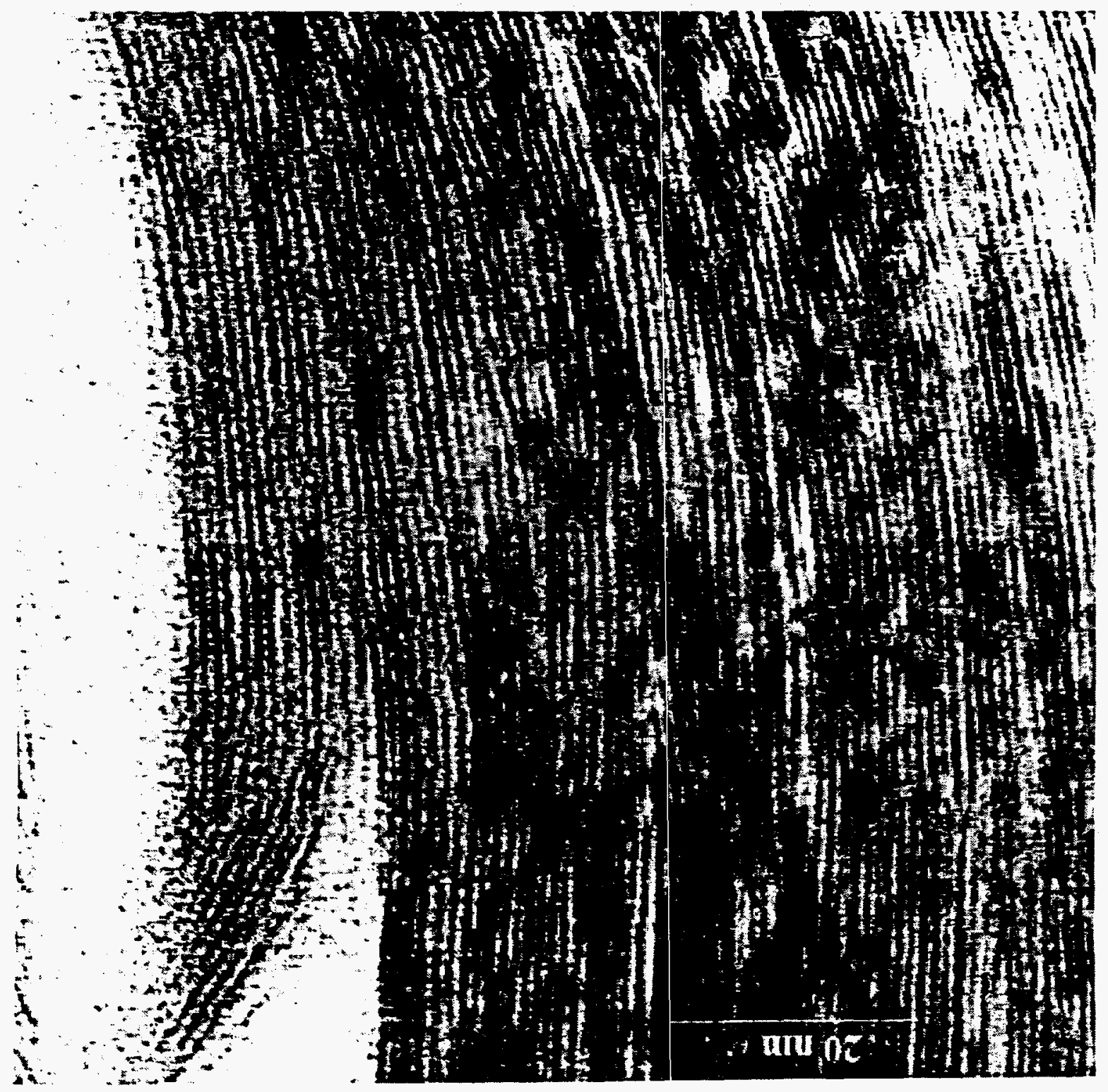




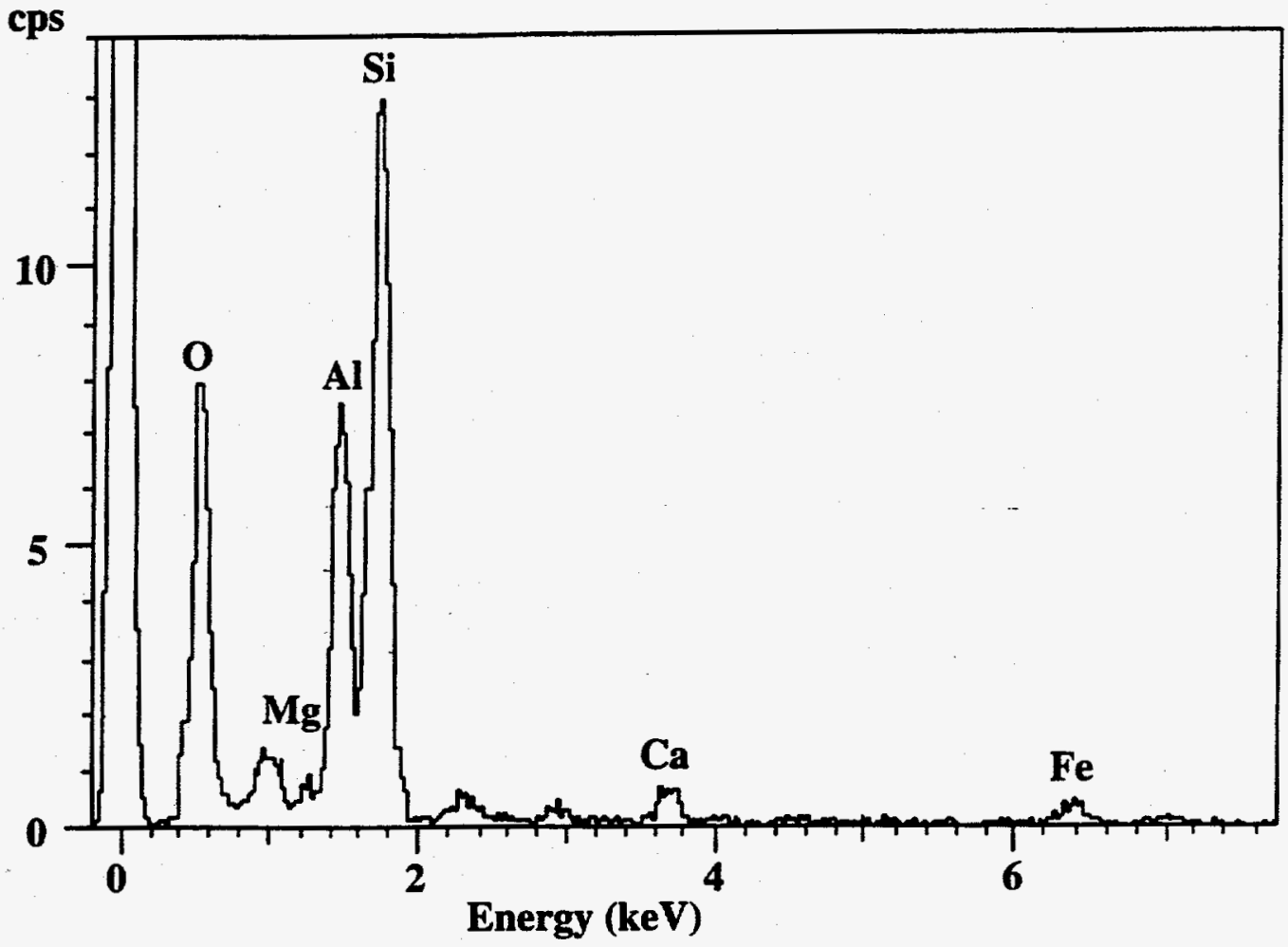

Figure 1-8: EDS spectrum from the smectite.

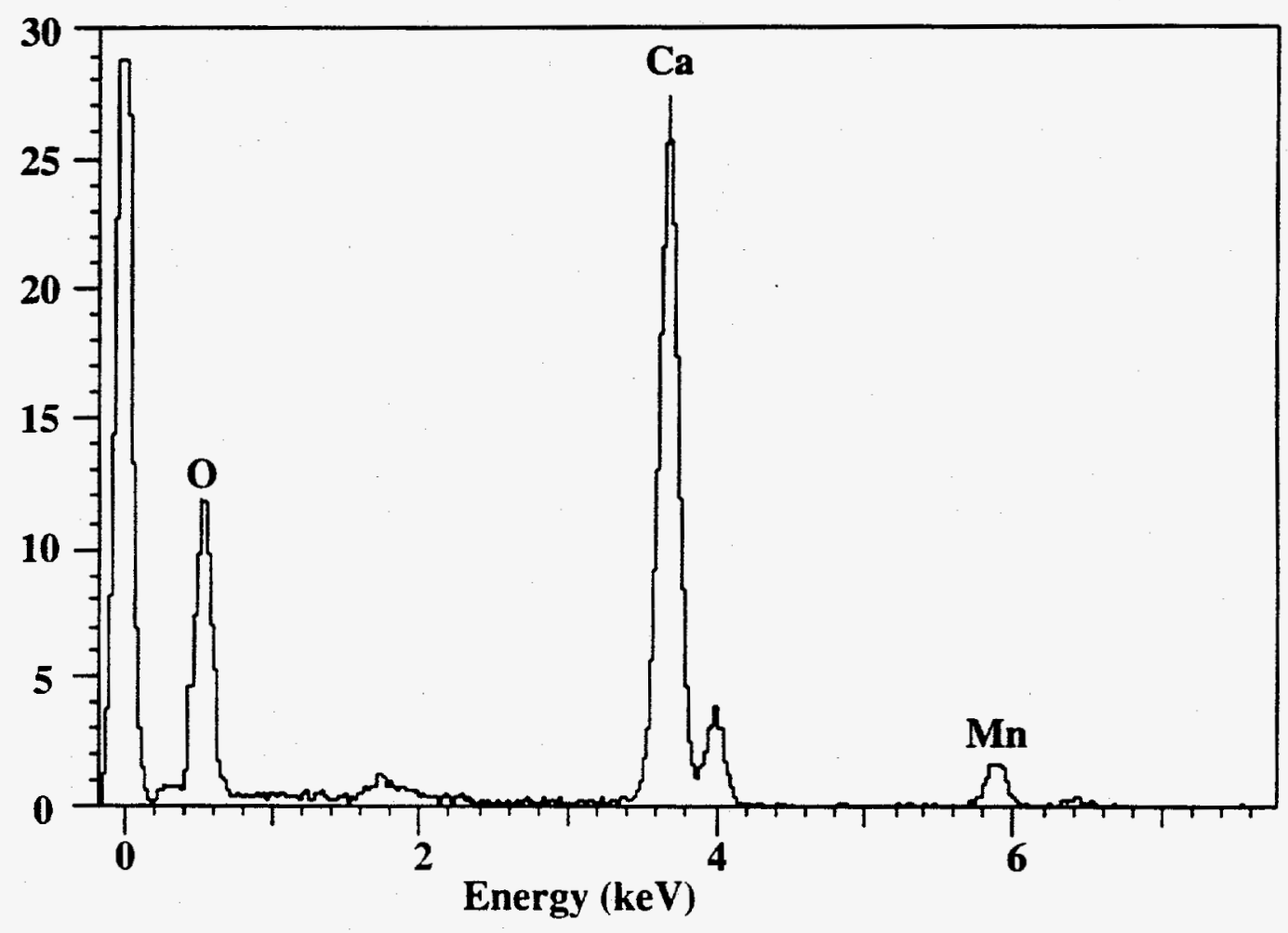

Figure 1-9: EDS spectrum from the Mn-bearing calcite. 


\section{Sample UE-20F/8668'}

This sample shows red coating layer. $\mathrm{X}$-ray powder diffraction shows that the coating layers contain hematite, quartz, illite, and small amount of $\mathrm{K}$ - and $\mathrm{Na}$-feldspars (Appendix 2). TEM results show the coating layer contains hematite, quartz, illite, highly disordered Mn-rich hydroxide, and small amount of $\mathrm{K}$ - and Na-feldspars. A TEM image of powder specimen shows euhedral hematite crystals (Figure 2-1). The size of the crystals range from $20 \mathrm{~nm}$ to $200 \mathrm{~nm}$. EDS spectra from the crystals show Fe and $\mathrm{O}$ peaks, i.e., Fe-oxide (Figure 2-2). SAED pattern also indicates the Fe-oxides is hematite (Figure 2-3). Some hematite crystals form inclusions in quartz (Figure 2-4, Figure 2-5). A Mn-rich phase was identified. It displays fiber-like shape (Figure 2-6, Figure 2-7). SAED patterns with strong streaking along (h01)* direction show highly disorder in structure (Figure 2-8, Figure 2-9). The SAED patterns are indexed based on birnessite unit cell. It is proposed that the Mn-rich phase consists of domains of birnessite, buserite, and todorokite. The structures of these phase are similar. EDS spectrum shows that the phase contains small amount of $\mathrm{Ca}$ (Figure 2-7). Results from EDS analyses show that the average atomic ratio between $\mathrm{Ca}$ and $\mathrm{Mn}$ is $1.12: 10$. It is proposed that $\mathrm{Mn}$ is dominated by $\mathrm{Mn}^{4+}$, and $\mathrm{Ca}$ is in the interlayer positions of birnessite/buserite domains and tunnel positions of todorokite domains. Figure 2-10 is a HRTEM image showing the two Mn-rich crystals and the boundary between them. Variation of (202) lattice fringes' periodicity indicates stacking disorder of the structural units along $(202)^{*}$ direction.

Figure 2-11 and Figure 2-12 show hematite, albite, and illitic clays. SAED patterns from the illite show streaking diffraction along $c^{*}$ direction (Figure 2-13, Figure 
2-14). There are stacking disorder in the illite, i.e., $1 \mathrm{M}_{d}$ illite. Compositions of the illite and one smectite from EDS analyses are illustrated in Table 2. HRTEM image shows layer termination of illite layers (Figure 2-15). An EDS spectrum from the Fe-bearing illite is illustrated in Figure 2-16.

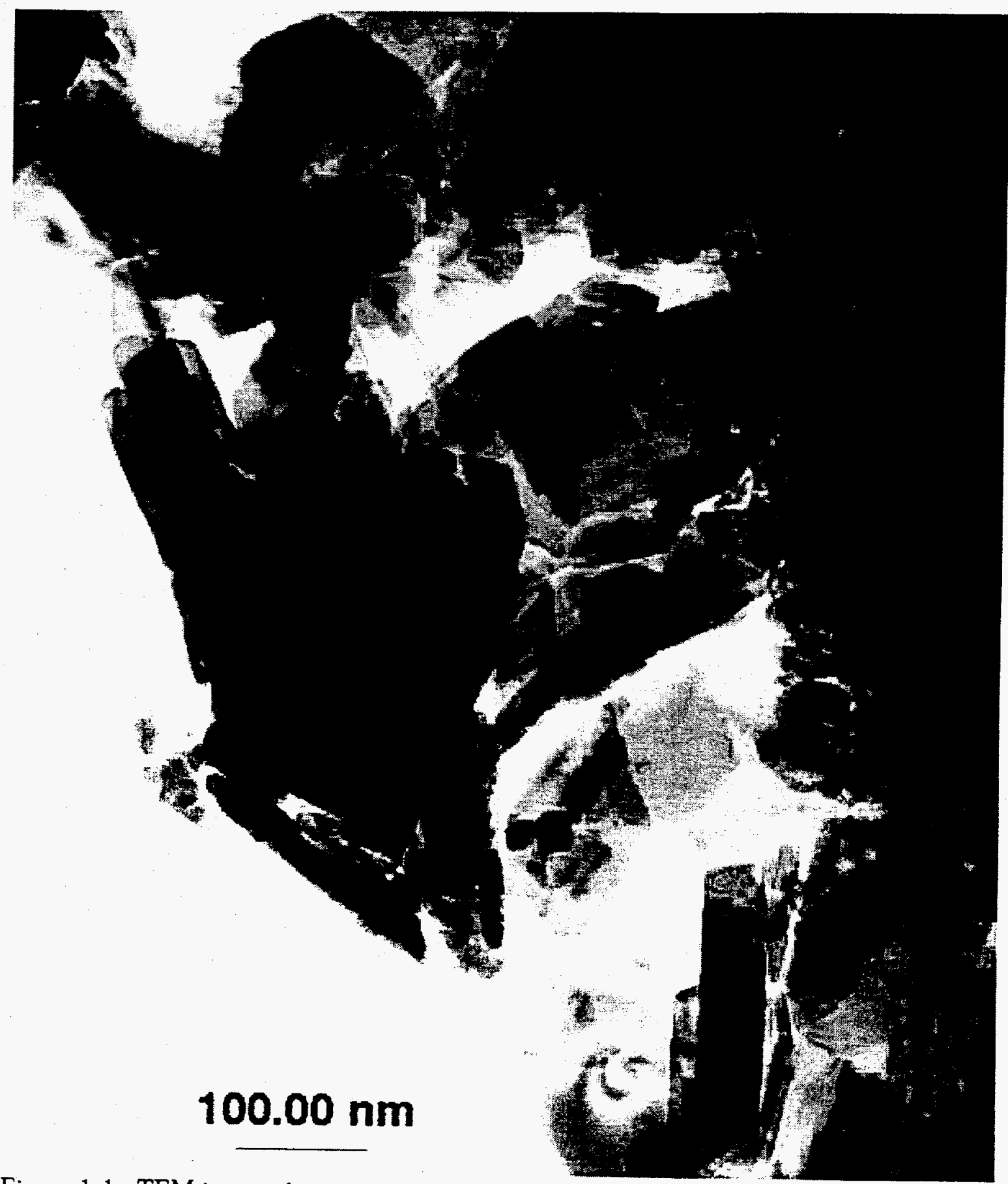

Figure 1-1: TEM image showing euhedral hematite crystals. 


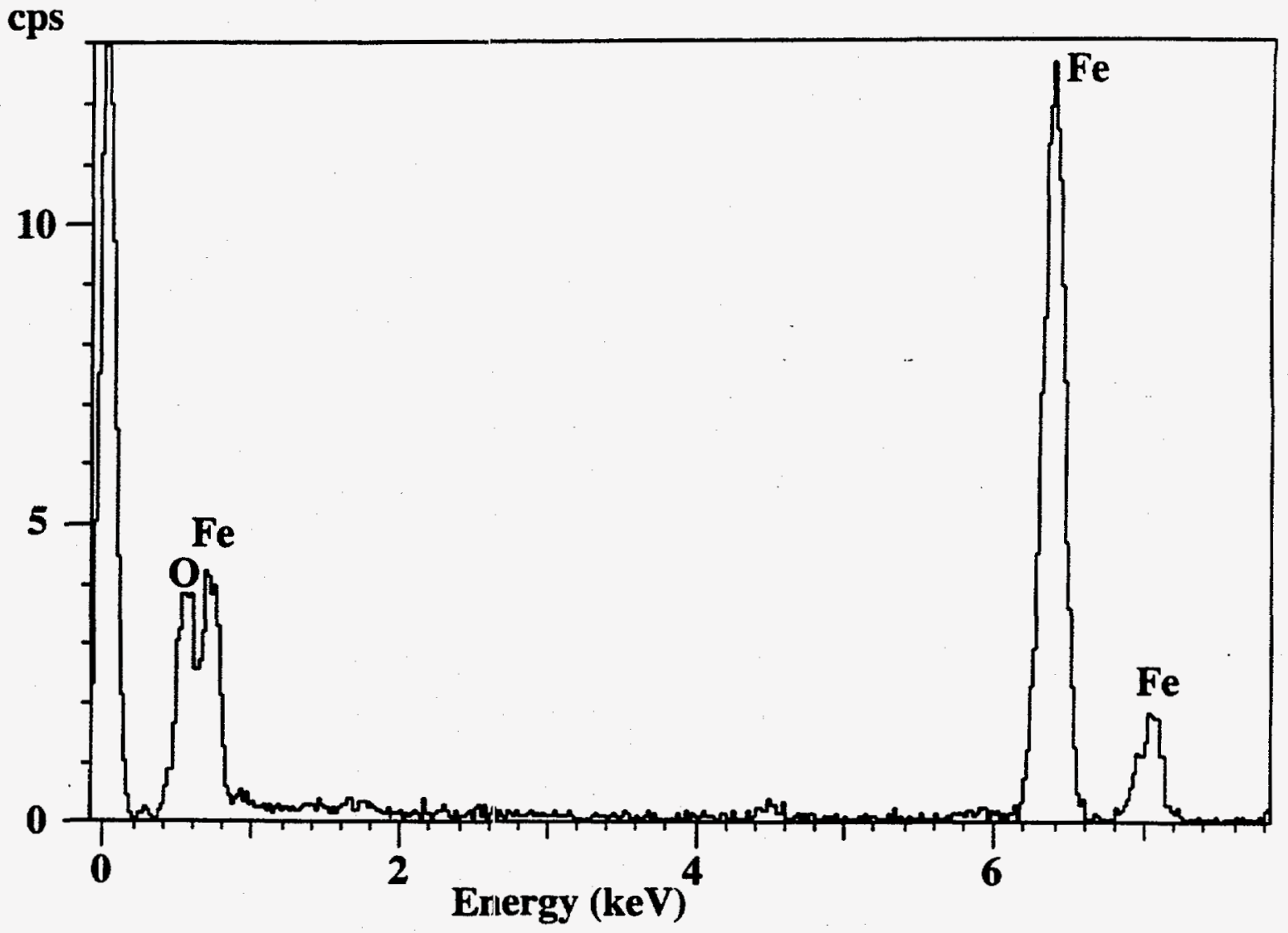

Figure 2-2: EDS spectrum from one hematite crystal showing $\mathrm{Fe}$ and $\mathrm{O}$ peaks. 


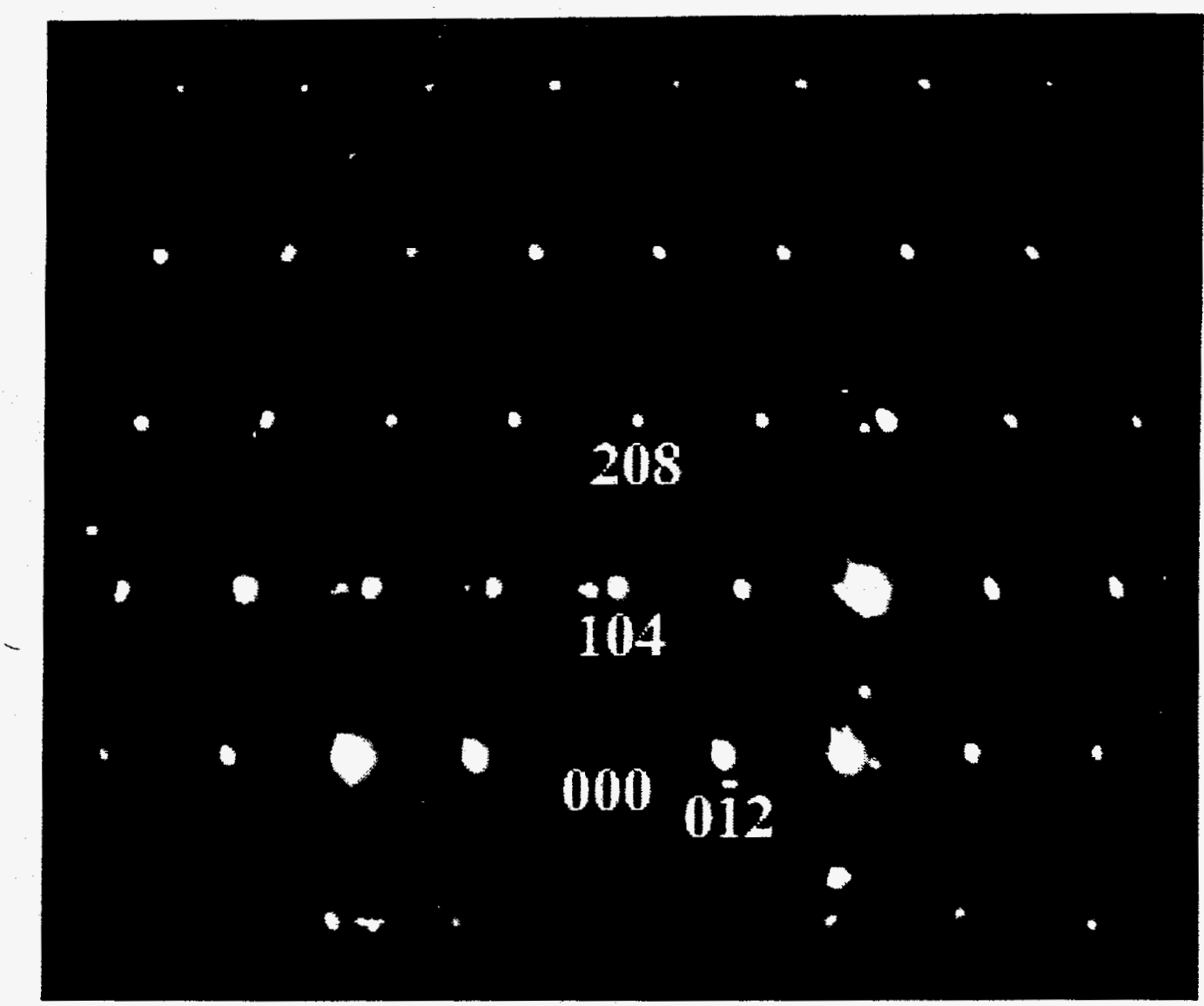

Figure 2-3: SAED pattern of hematite. 


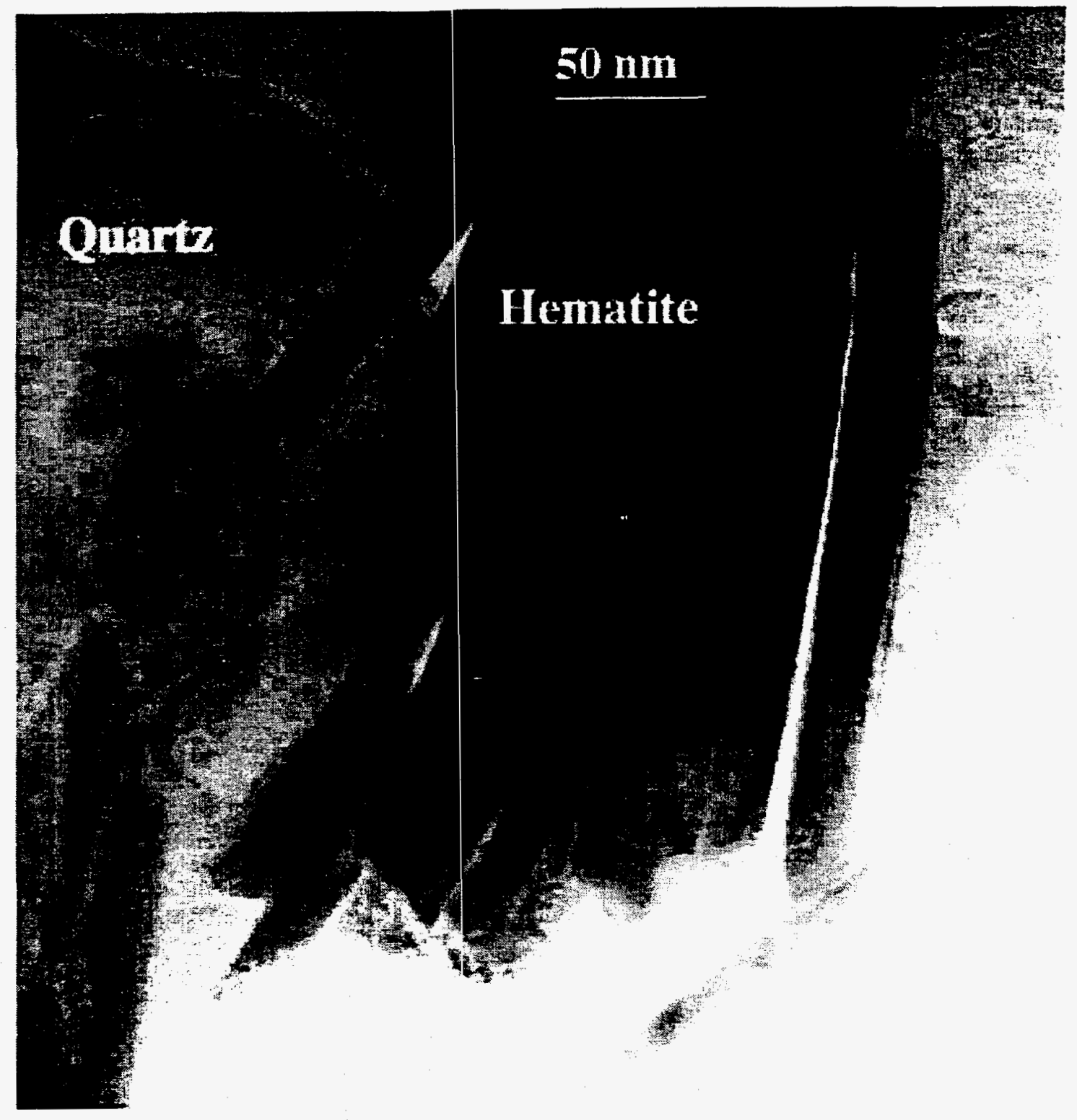

Figure 2-4: TEM image showing hematite plates in a quartz crystal. 
[ [e]SאIJ

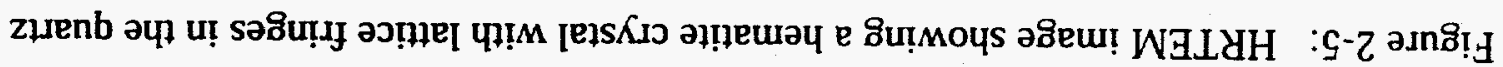

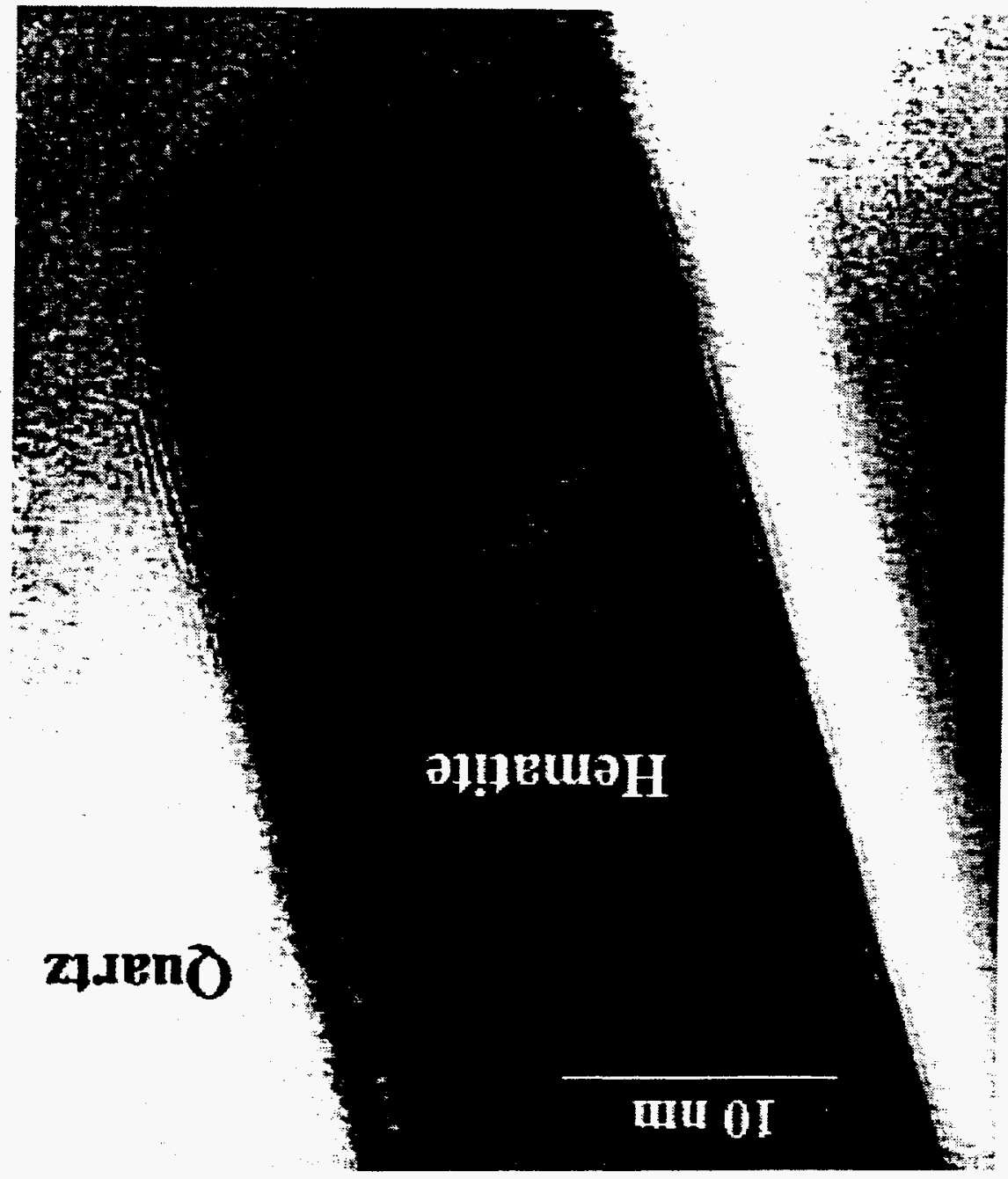




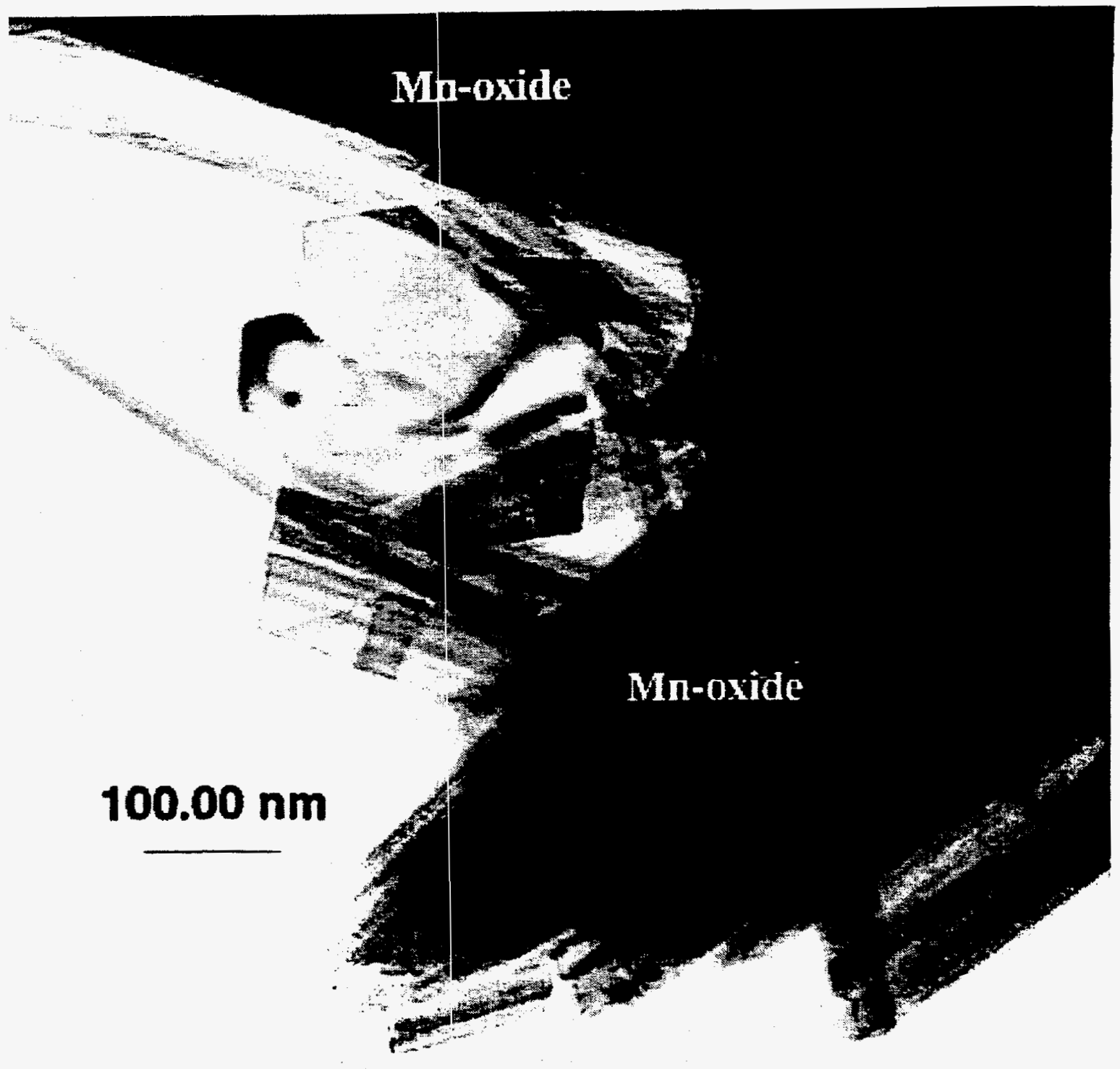

Figure 2-6: TEM image showing a Mn-rich phase and a hematite crystal. 


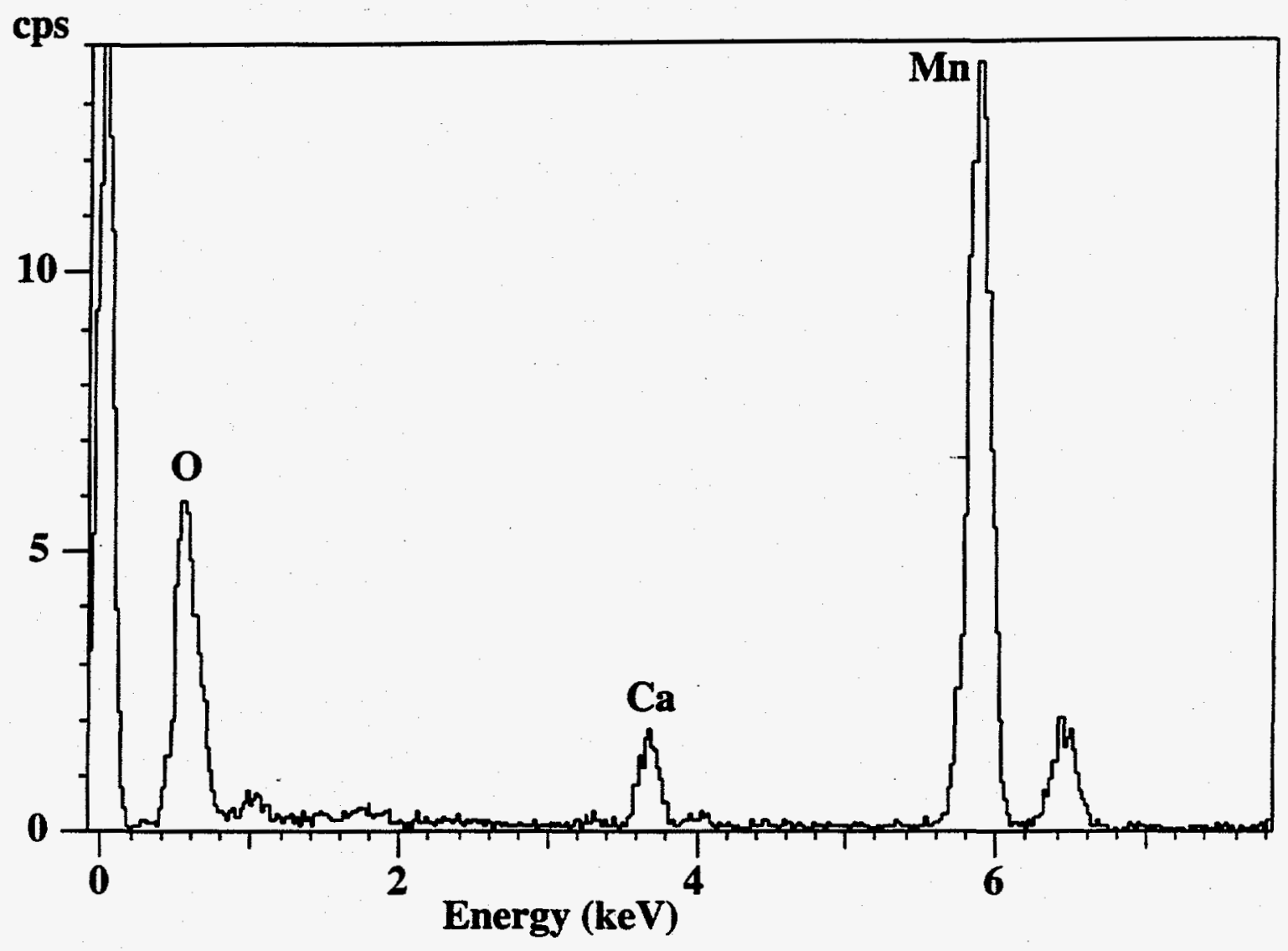

Figure 2-7: EDS spectrum from the Mn-rich phase showing $\mathrm{Mn}, \mathrm{Ca}$, and $\mathrm{O}$ peaks. 


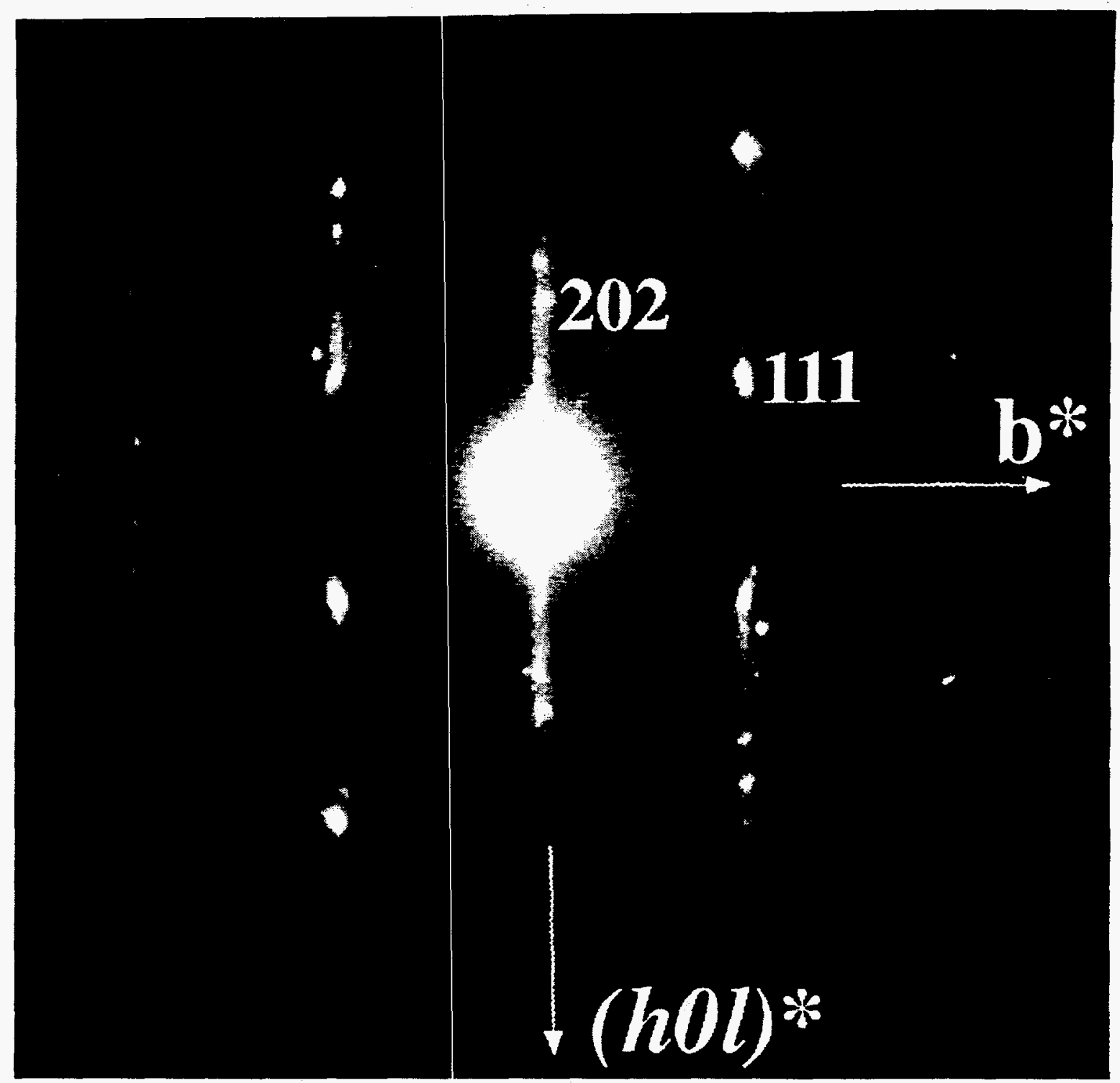

Figure 2-8: SAED pattern from the Mn-rich phase showing streaking diffraction along $(\mathrm{h} 01)^{*}$ direction. The streaking indicates highly disorder in the structure. Indexes of the SAED pattern are based on birnesite unit cell. 


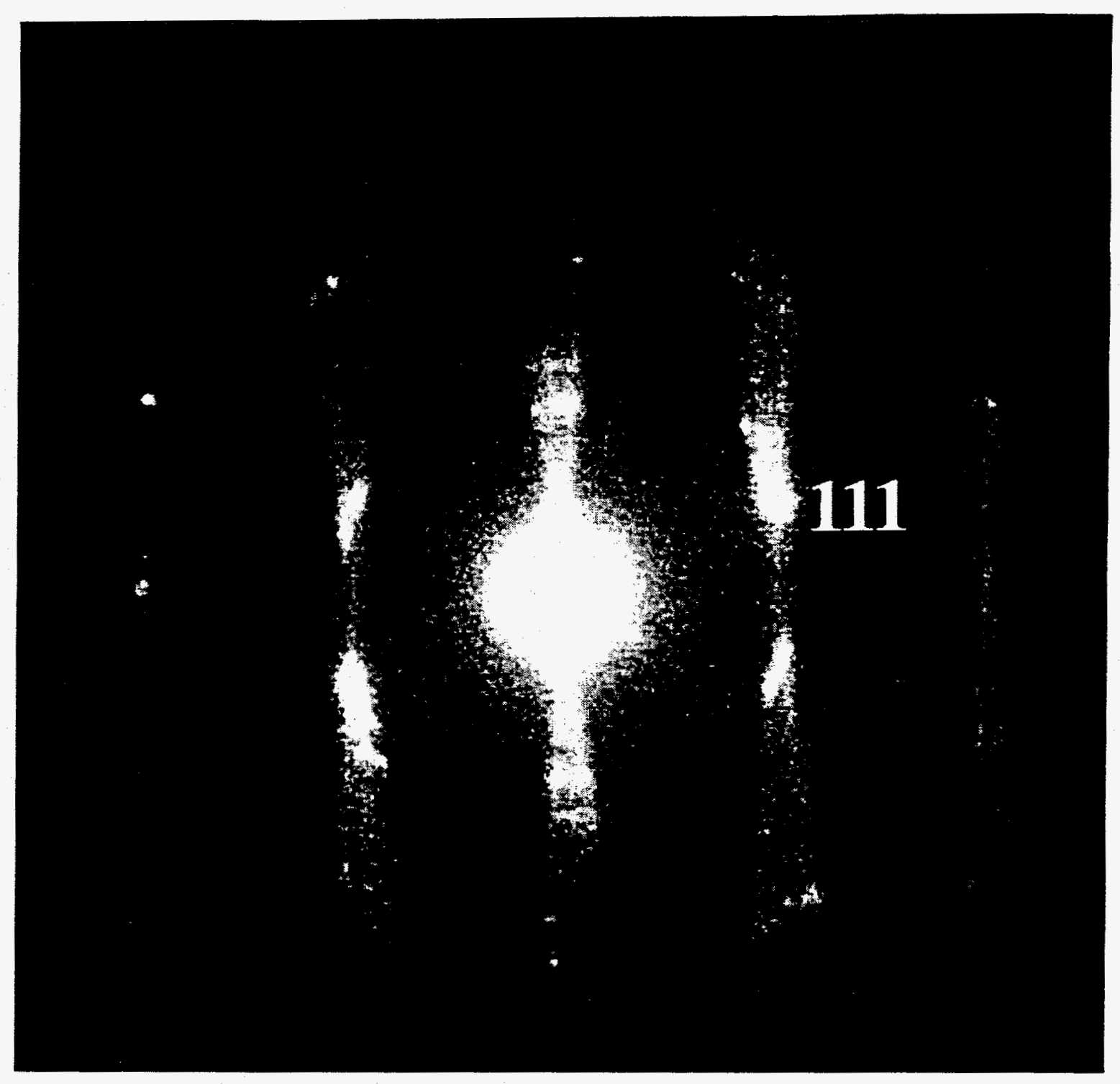

Figure 2-9: SAED pattern from the Mn-rich aggregate showing streaking diffraction along (h0l)* direction. 


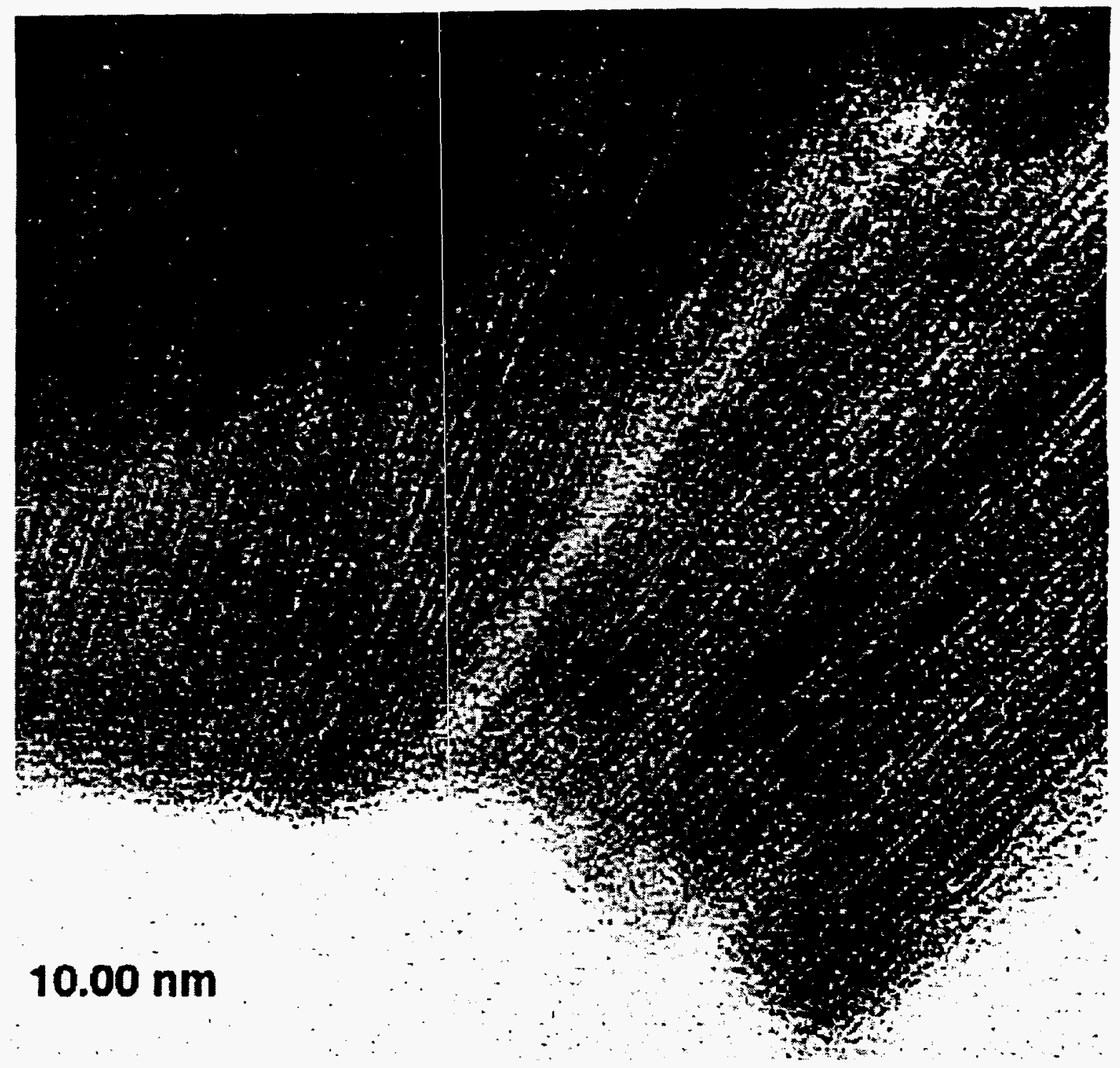

Figure 2-10: TEM image showing the two Mn-rich crystals and the boundary between them. Variation of (202) lattice fringes periodicity indicates stacking disorder of the structural unites along $(202)^{*}$ direction. 


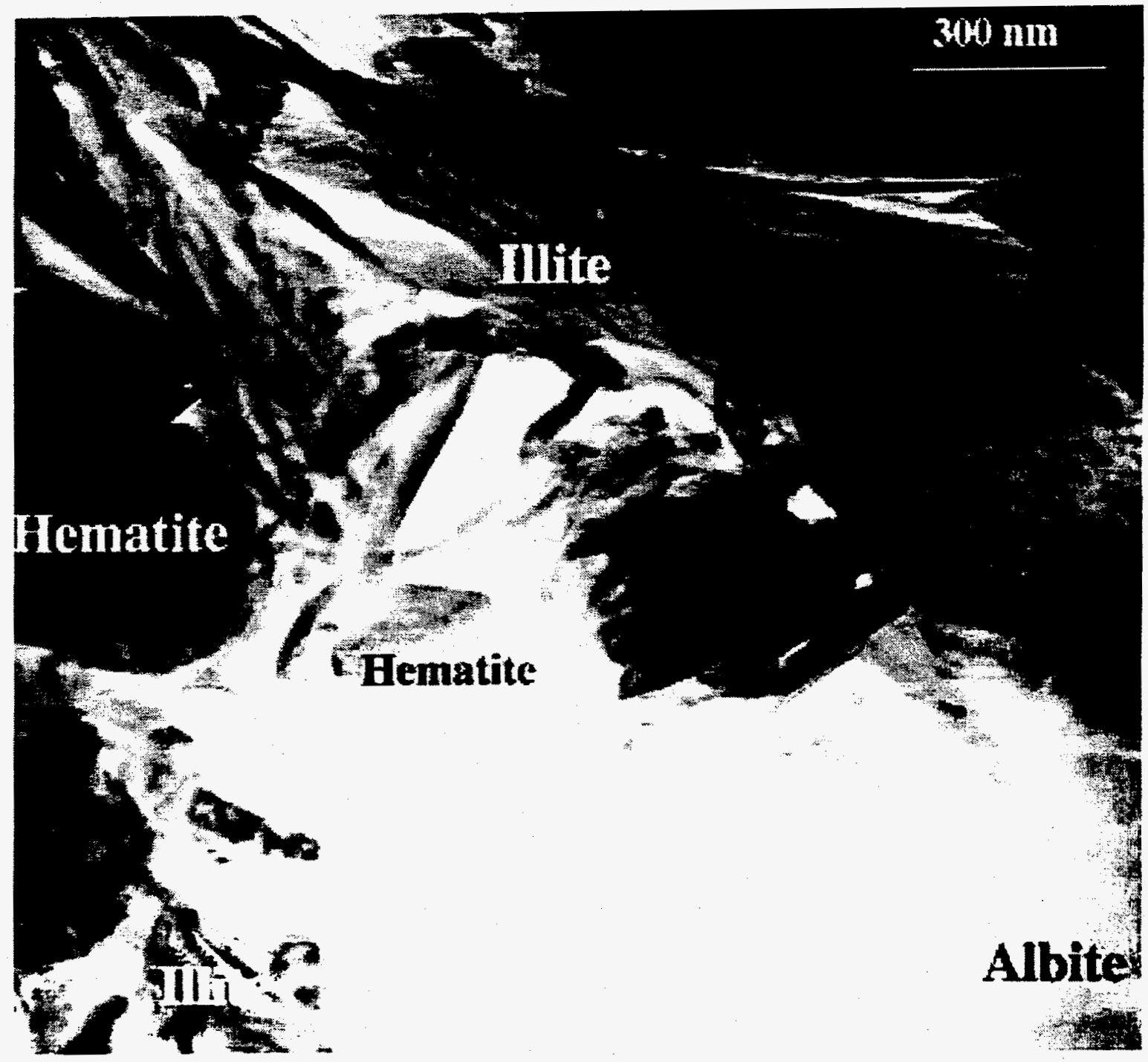

Figure 2-11: TEM image showing hematite coexisting with illite and albite. 


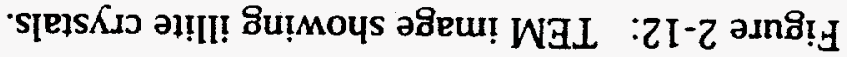

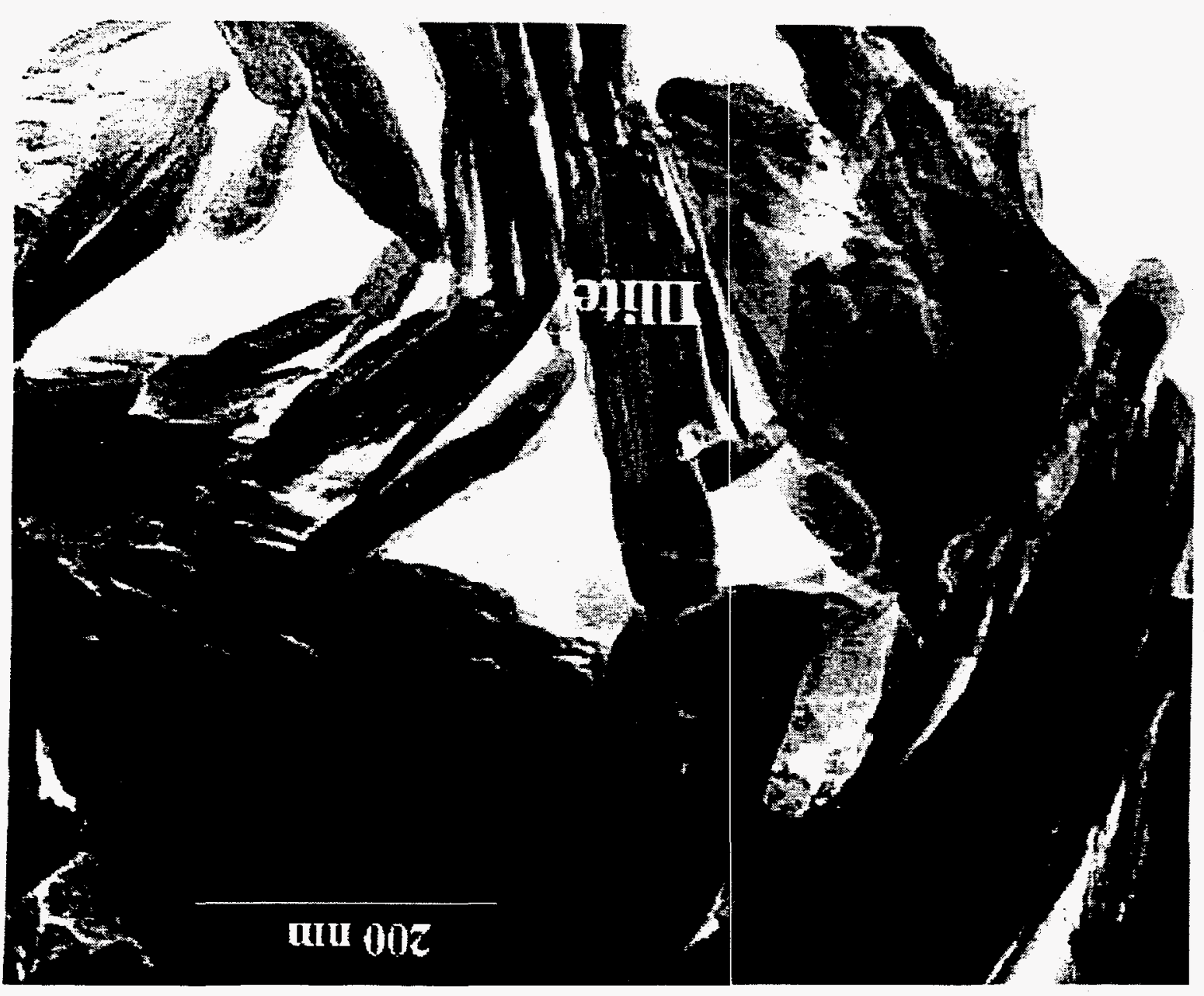




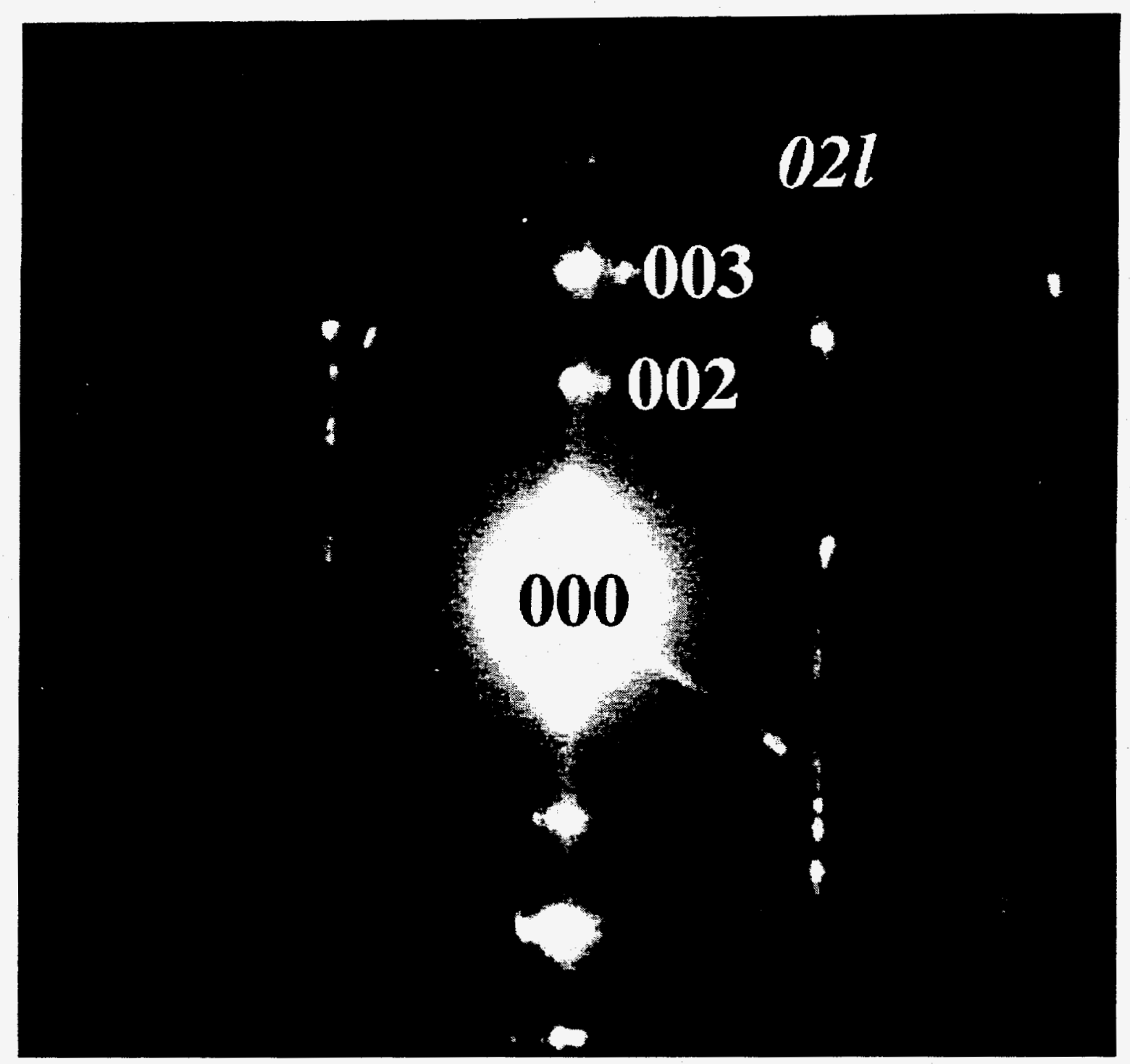

Figure 2-14: A [100] zone-axis SAED pattern of the illite sowing streaking along $\mathrm{c}^{*}$ direction. 


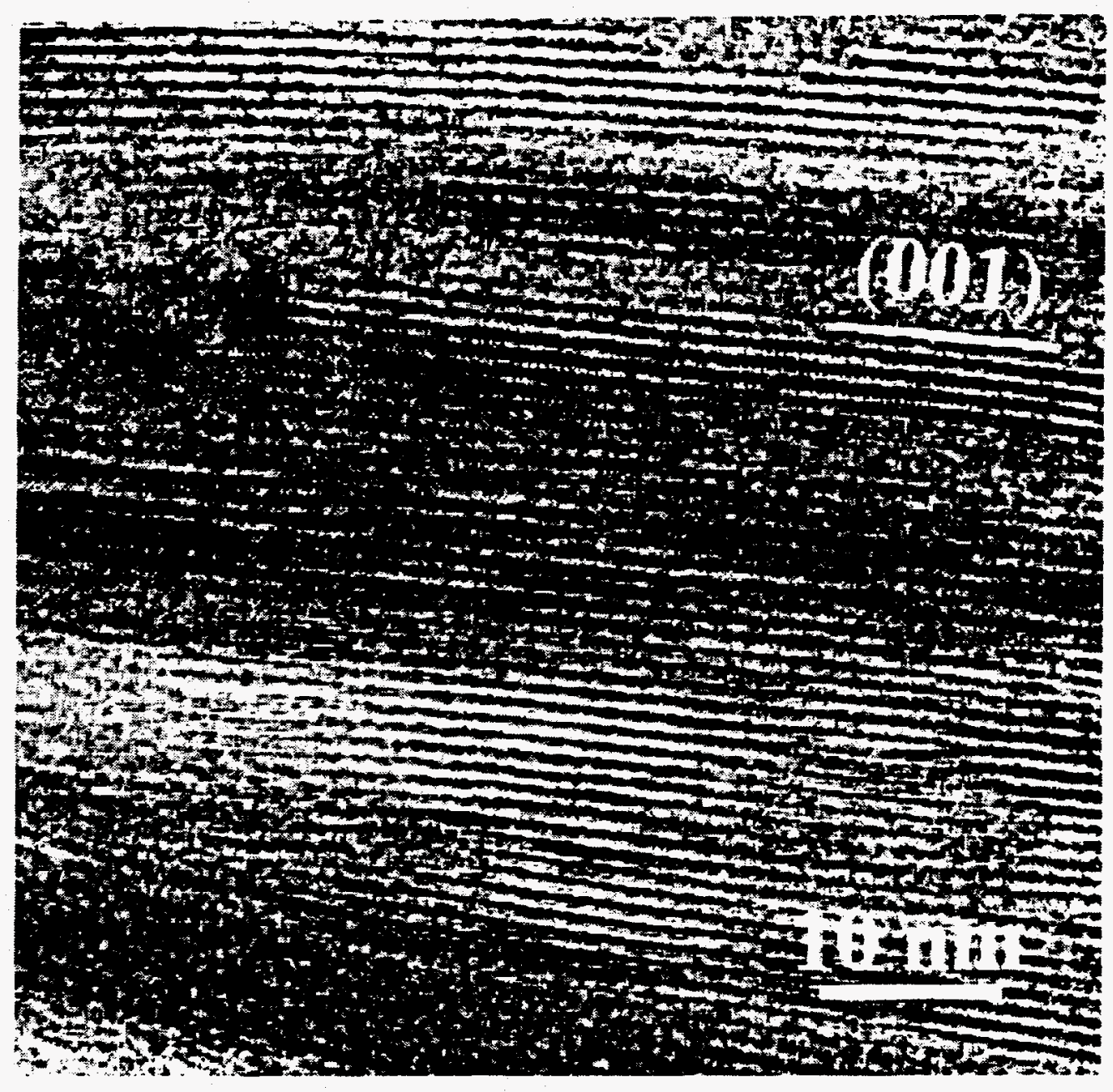

Figure 2-15: HRTEM image showing illite layers and layer termination. 


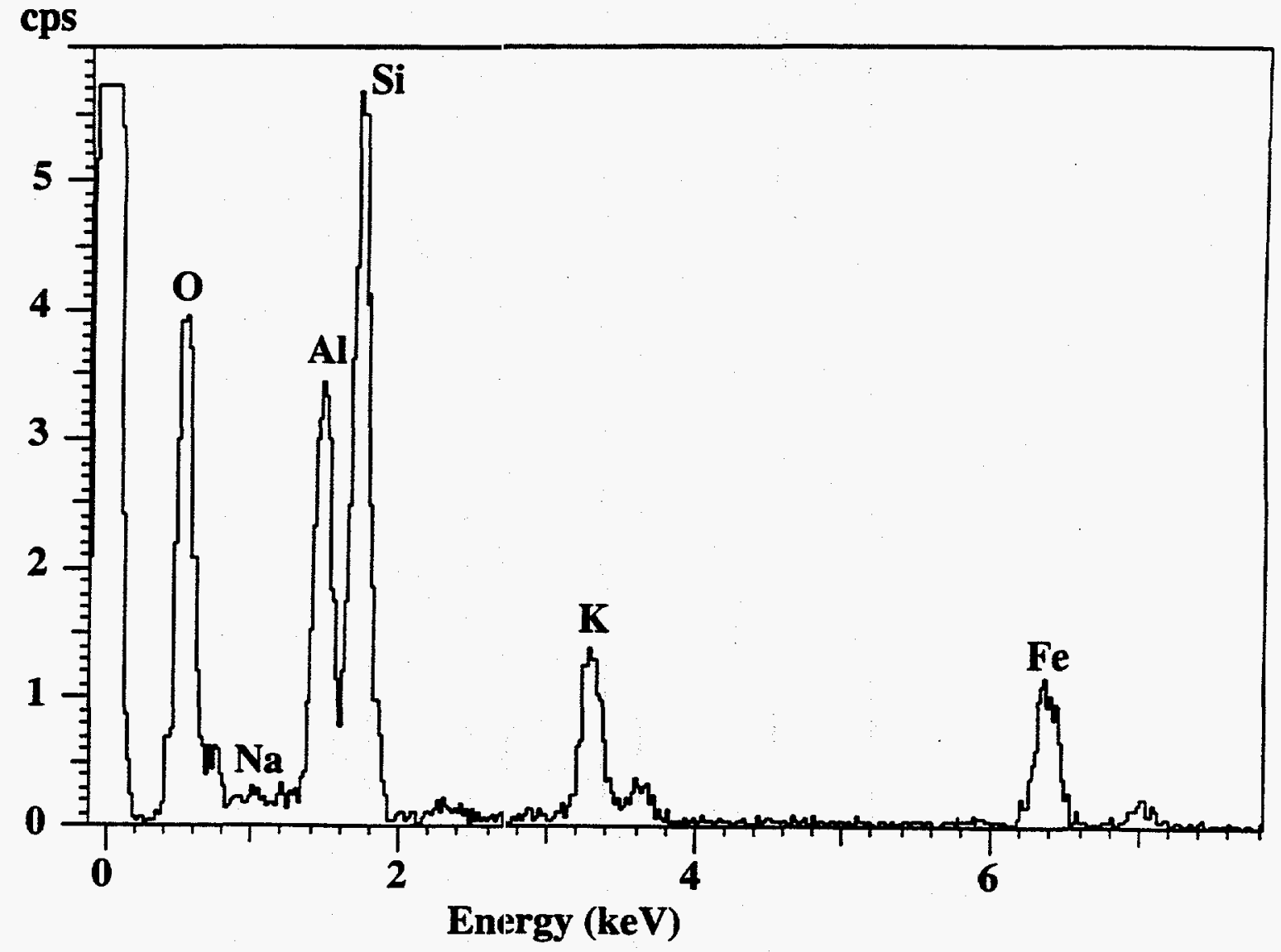

Figure 2-16: EDS spectrum from an Fe-bearing illite crystal. 


\section{Sample UE-20F/13674'}

This sample shows yellowish thin coating layer. X-ray powder diffraction shows that the coating layer contains calcite, quartz, and small amount of $7-\AA$ layer silicates (i.e., either kaolinite or serpentine) (Appendix 3). TEM results show that the coating layer contains calcite, quartz, berthierine (Fe-bearing serpentine-like phase), illite, and goethite. Figure 3-1 shows an illite crystal with a calcite grain on it. EDS result shows that the illite is relative low in $\mathrm{K}$ content with respect to normal illite (Figure 3-2, Table 3a). It is proposed that the illite may be a mixed-layer crystal composed of illite and smectite layers. Figure 3-3 shows a berthierine crystal with needle-like goethite inclusion. SAED pattern (Figure 3-4) from the bertheirne crystal indicates that the crystal is a layer silicate. Based on the composition of from EDS analyses (Figure 3-6, Table $3 b$ ), it can be inferred that the Fe-rich layer silicate is berthierine. HRTEM image (Figure 3-5) shows (010) lattice fringes of the needle-like goethite crystal in the berthierine. An EDS spectrum from neighboring Fe-Mn-bearing calcite is also illustrated in Figure 3-7. 


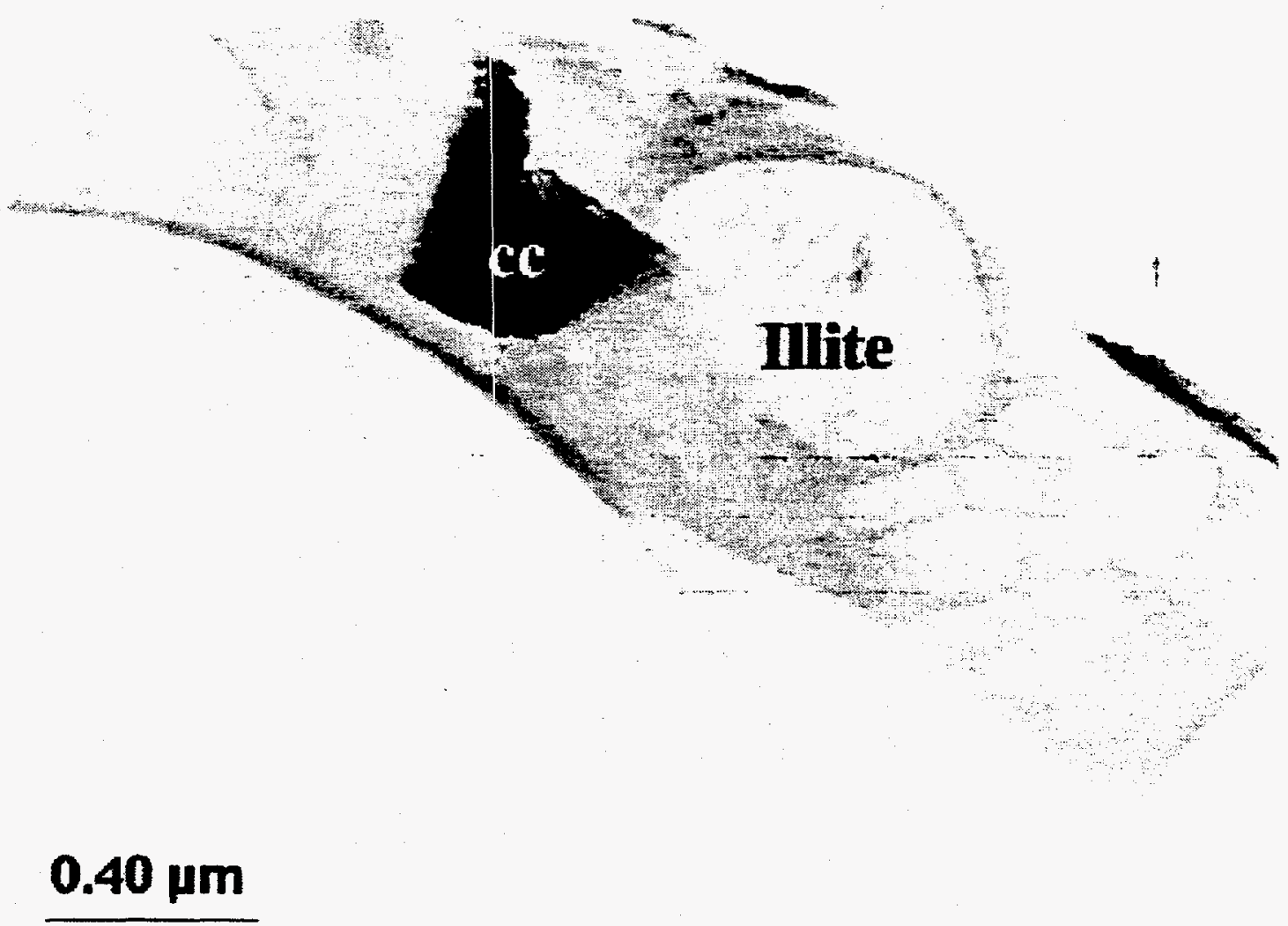

Figure 3-1: TEM image showing an illite crystal with a calcite grain on it.

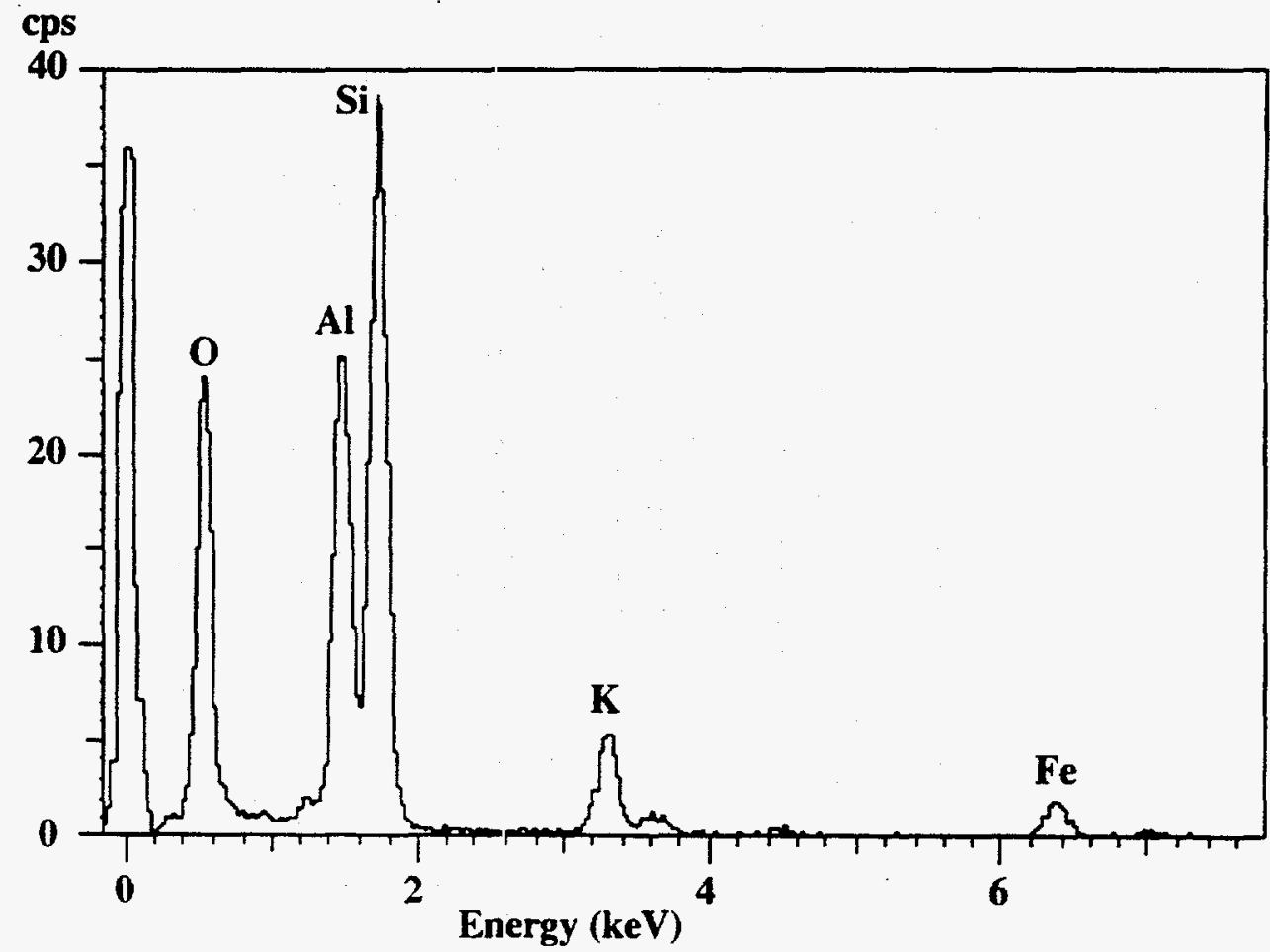

Figure 3-2: EDS spectrum from the illite crystal. 


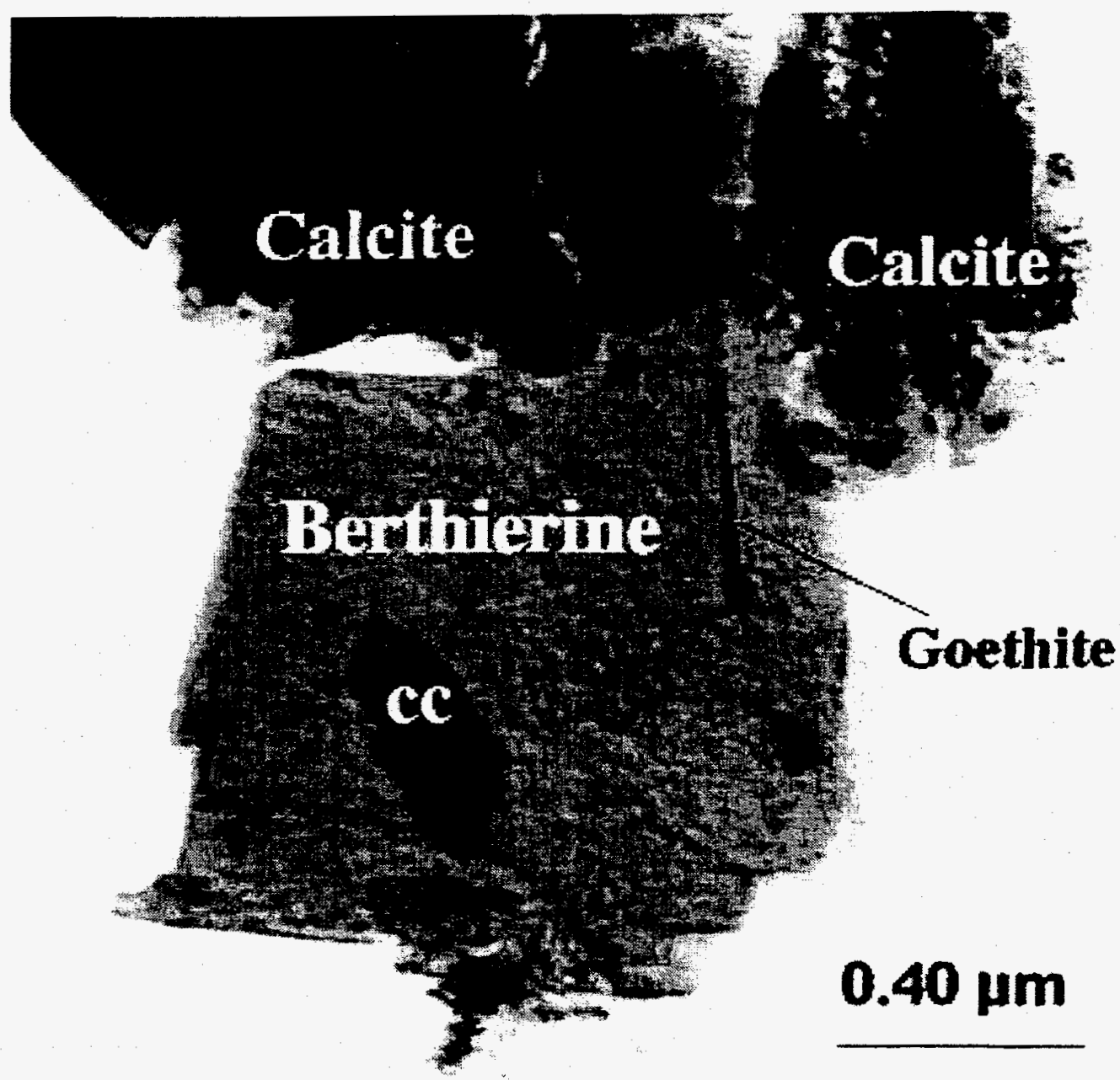

Figure 3-3: TEM image showing a berthierine crystal with a needle-like goethite crystal. 


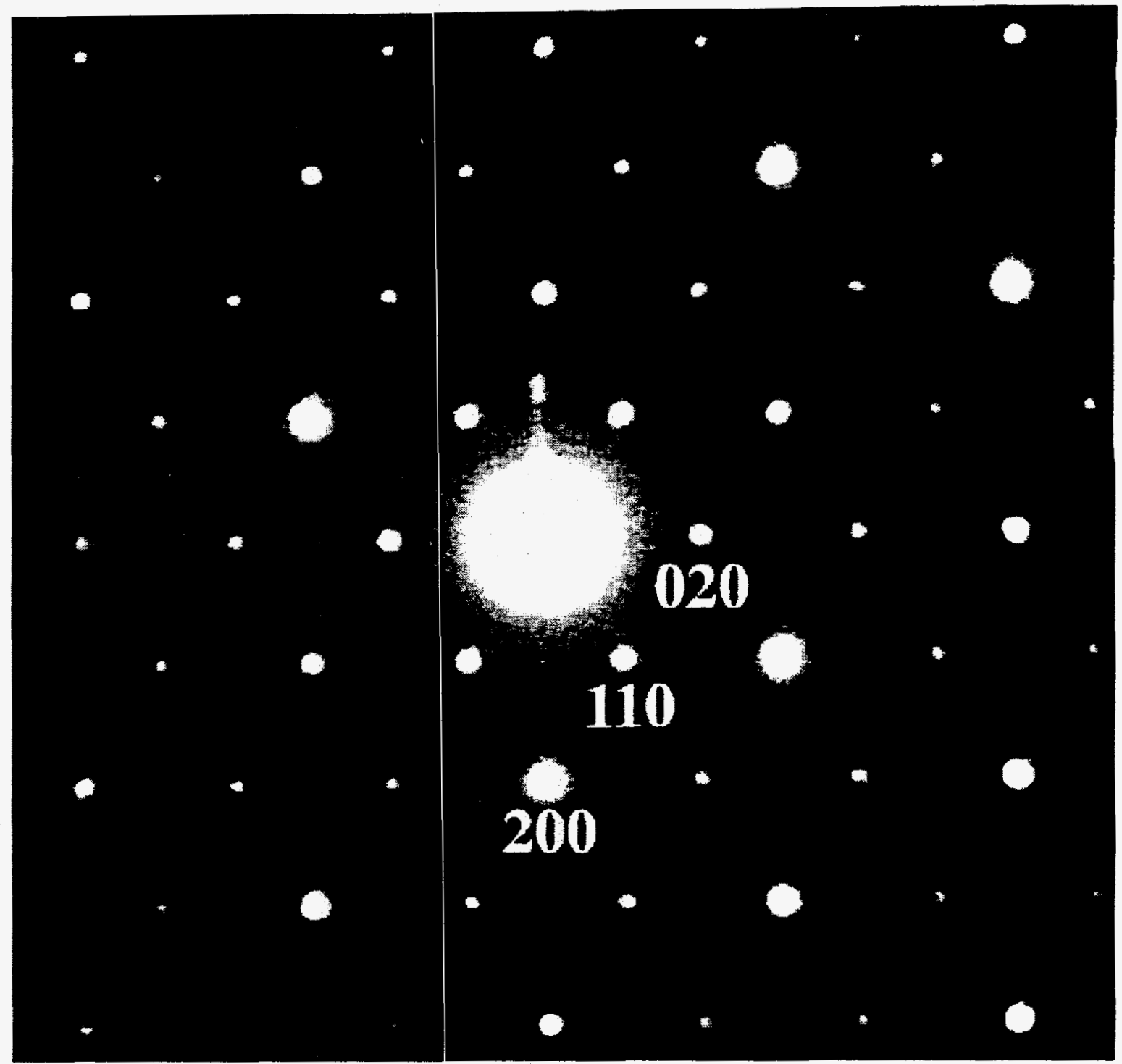

Figure 3-4: [001] zone axis SAED patterns from the berthierine crystal. 


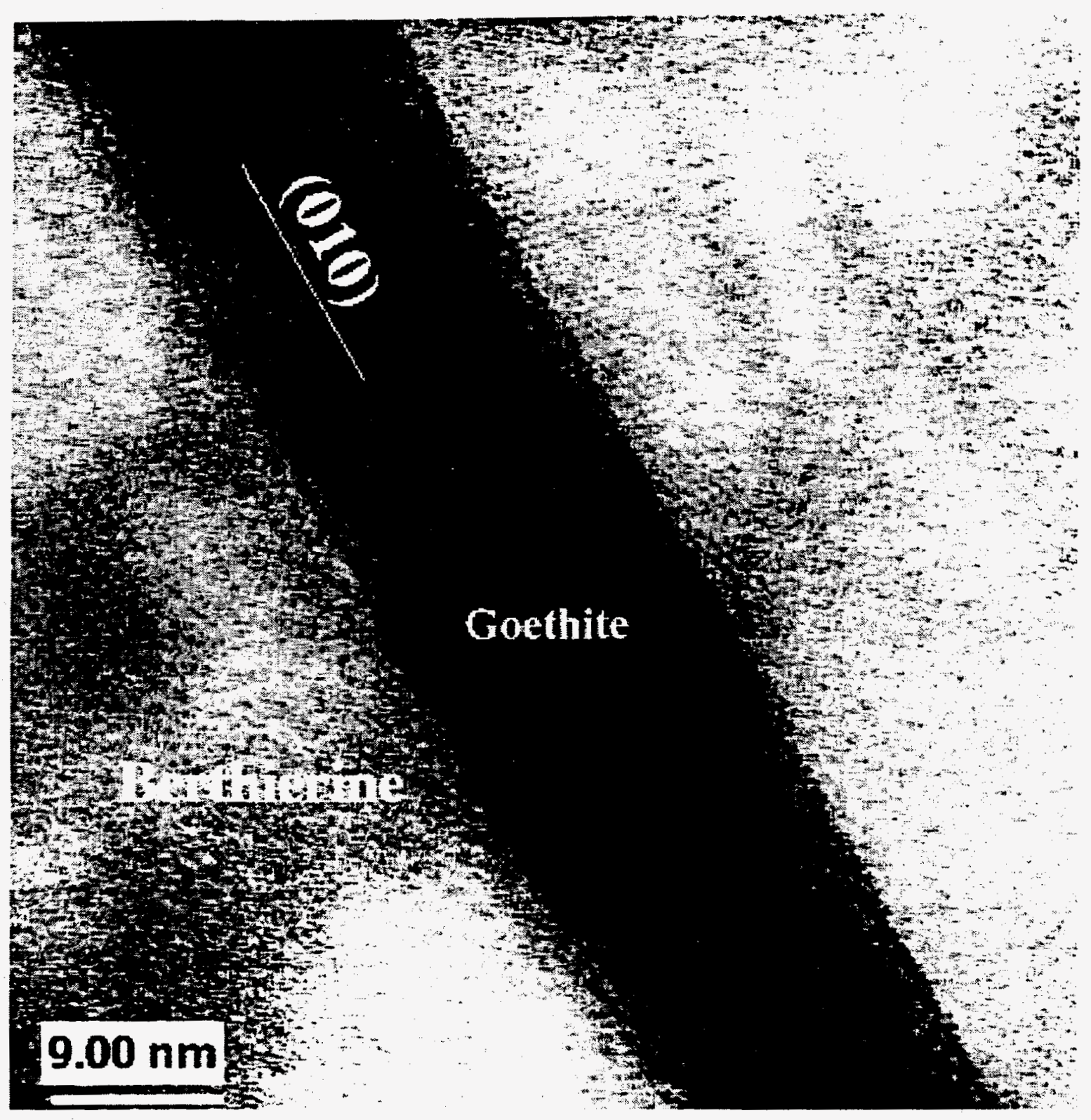

Figure 3-5: HRTEM image showing the needle-like goethite crystal and its host berthierine crystal. 


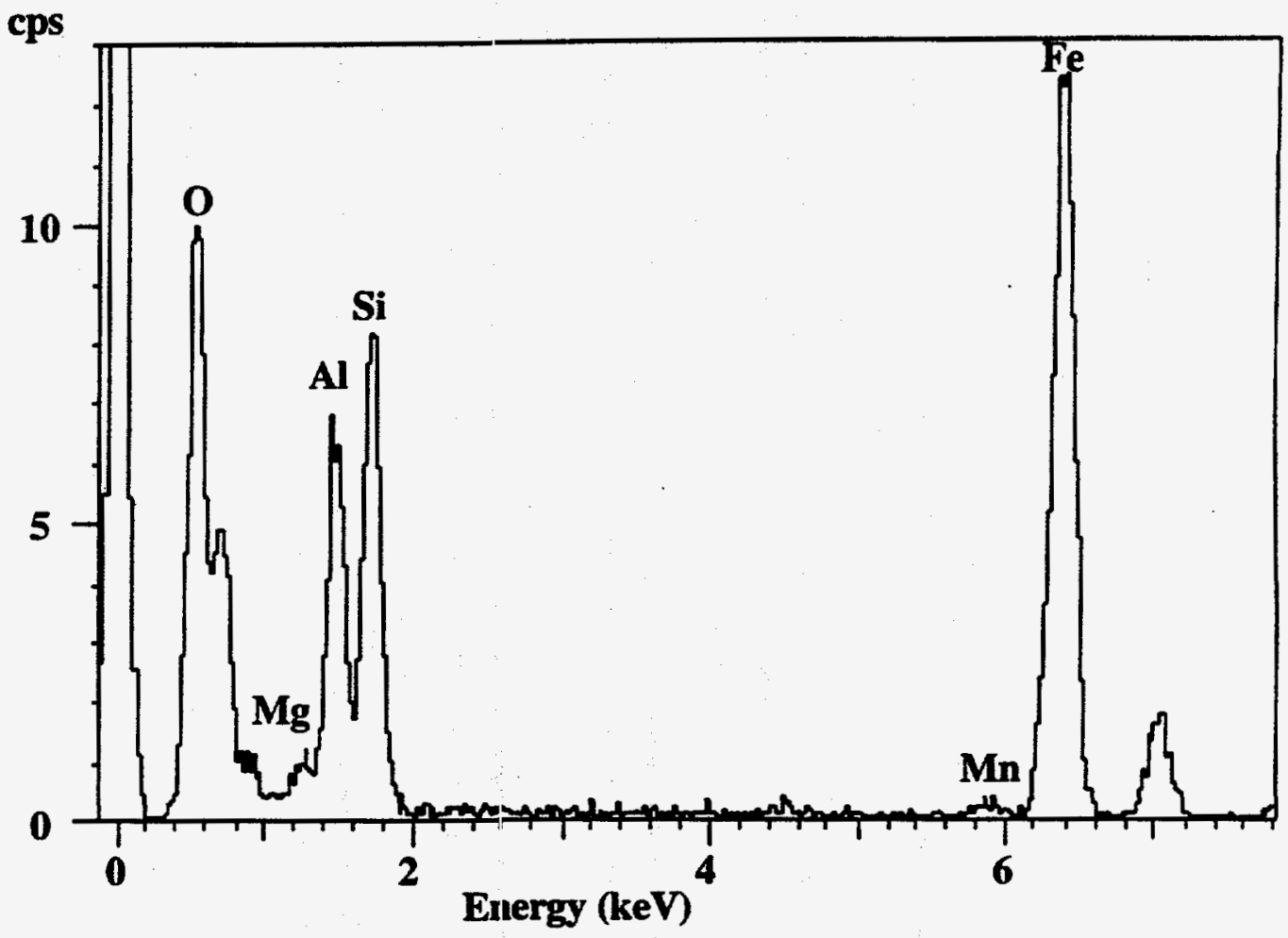

Figure 3-6: An EDS spectrum from the berthierine crystal.

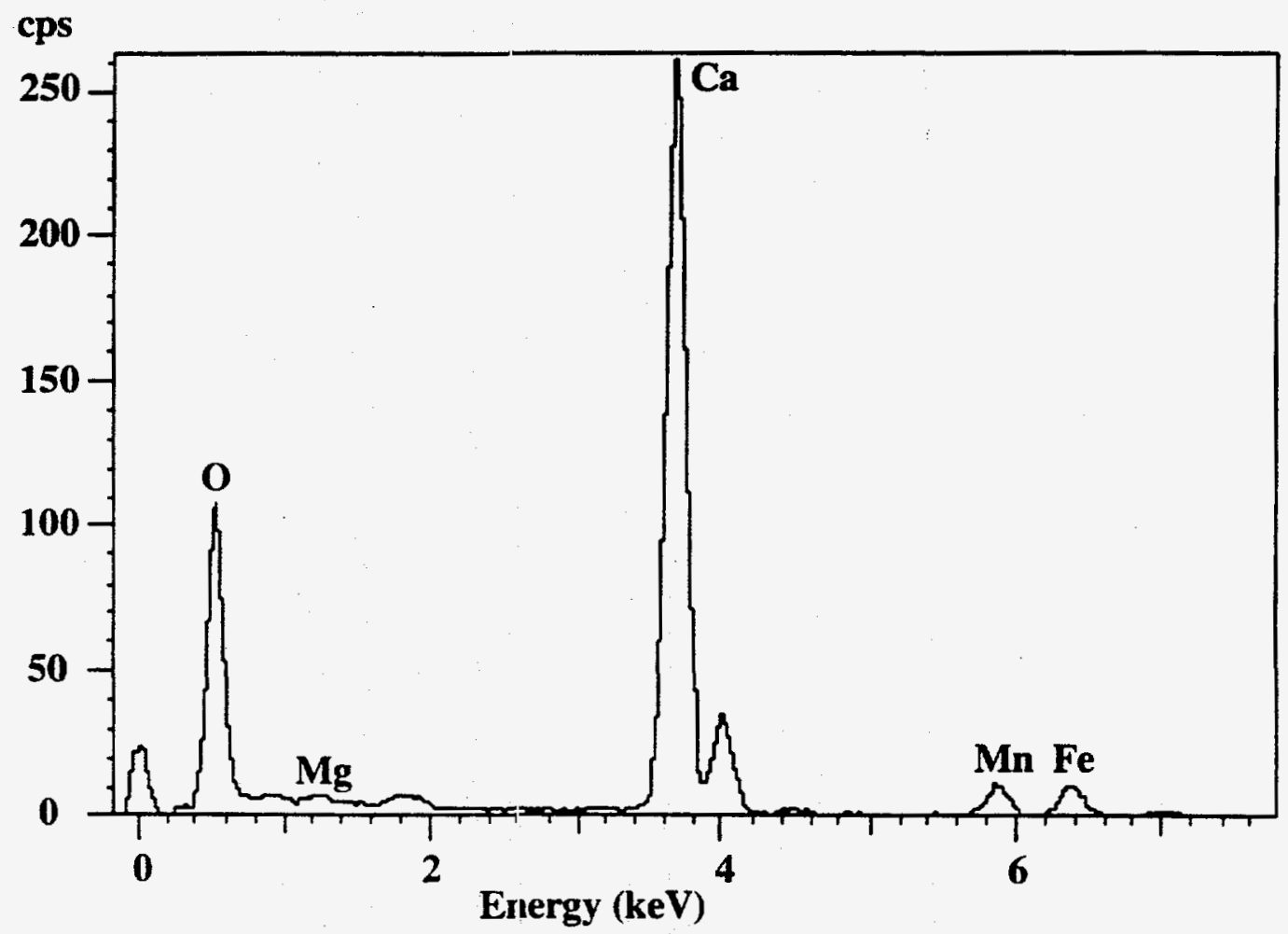

Figure 3-7: An EDS spectrum from a Fe-Mn-bearing calcite. 


\section{Sample PM-2/5893'}

This sample shows white coating layer and veins. $X$-ray powder diffraction of the coating layers shows dolomite, calcite, quartz, and small amount of illit clay (Appendix 4). TEM results show the coating layer contains calcite, dolomite, illite, and quartz. No $\mathrm{Mn}-\mathrm{Fe}$ oxides and zeolite were observed in the coating layer of this sample.

Figure 4-1 shows illitic clays, dolomite, and quartz. Figure 4-2 and Figure 4-3 show aggregates of the illite clays. SAED patterns show both 2-layer $\left(2 \mathrm{M}_{2}\right)$ and disordered (1-M $\mathrm{M}_{\mathrm{d}}$ ) polytypes (Figure 4-4, Figure 4-5). HRTEM images show intergrowth of 1-layer and 2-layer illite polytypes (Figure 4-6) and low angle boundaries between the neighboring illite crystals (Figure 4-7). EDS results from different areas of the illite clay show that composition varies from crystal to crystal. Low content of $\mathrm{K}$ in the interlayer position may indicates smectite layers in the mixed-layer illite/smectite clay (Table 4). All $\mathrm{Fe}$ in the illitic clays are assumed to be ferrous $\mathrm{Fe}^{2+}$, even though it may be in the form of ferric $\mathrm{Fe}^{3+}$. 


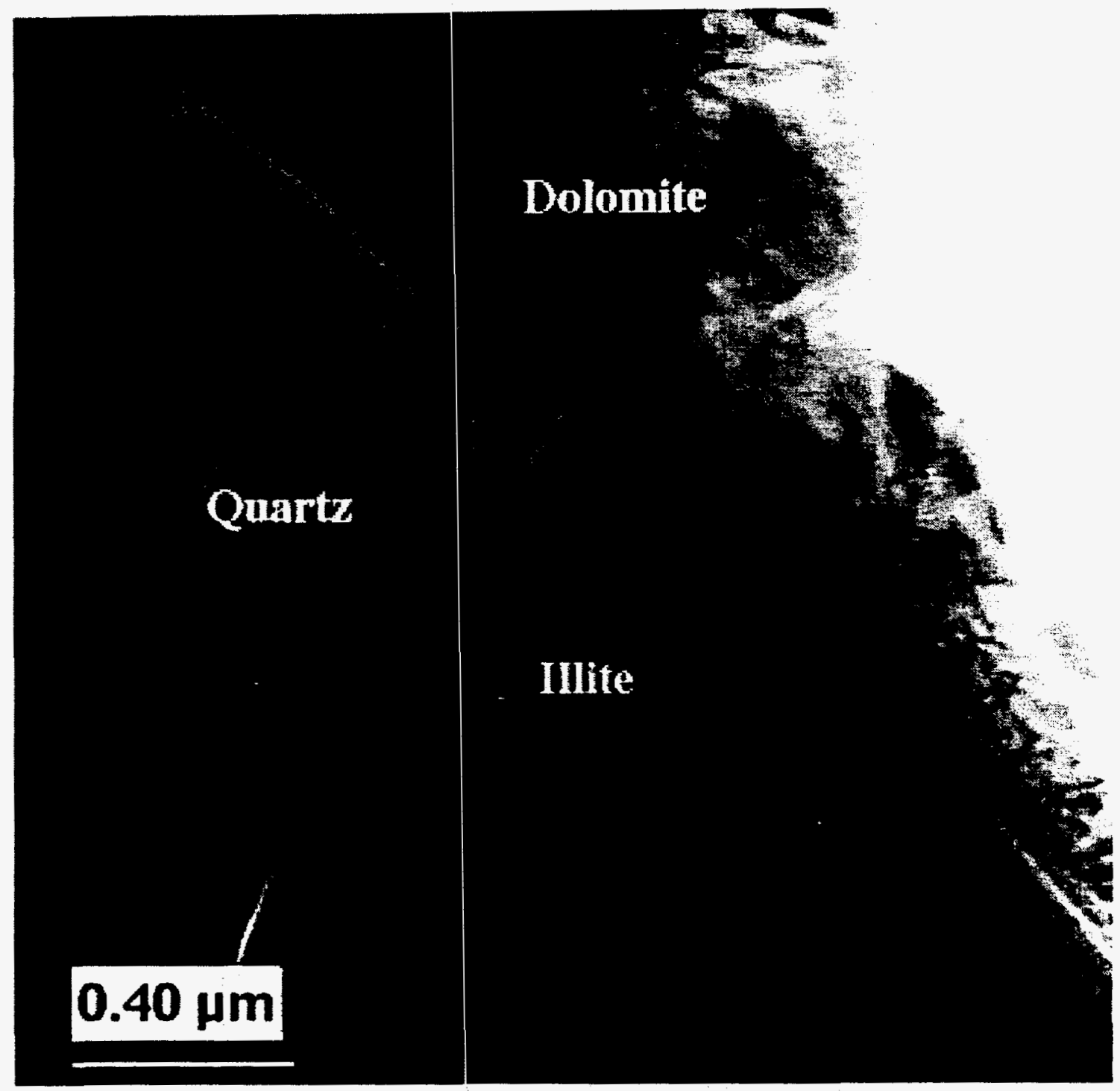

Figure 4-1: TEM image showing illitic clays, dolomite, and quartz. 


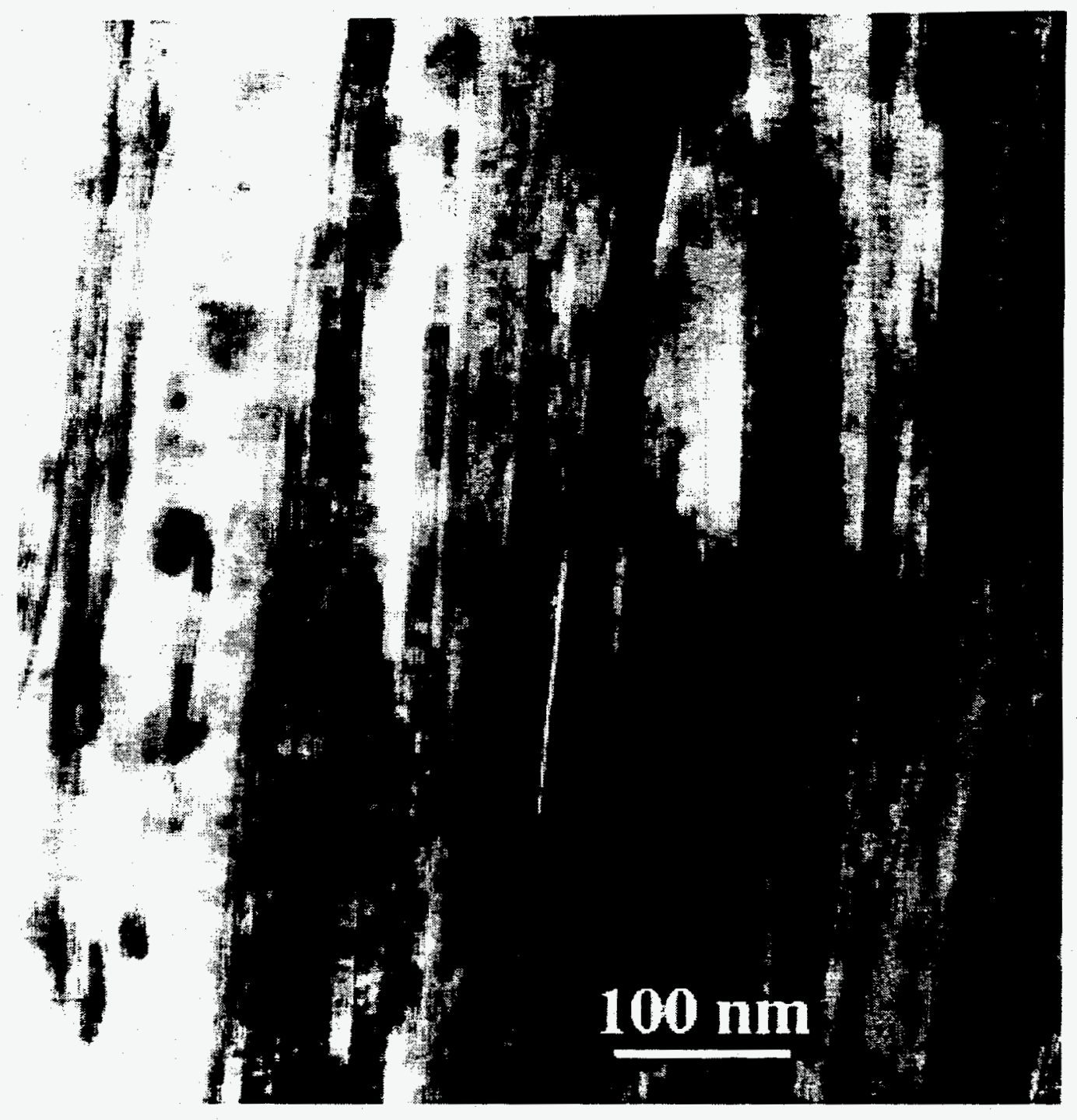

Figure 4-2: TEM image showing illitic clays. 


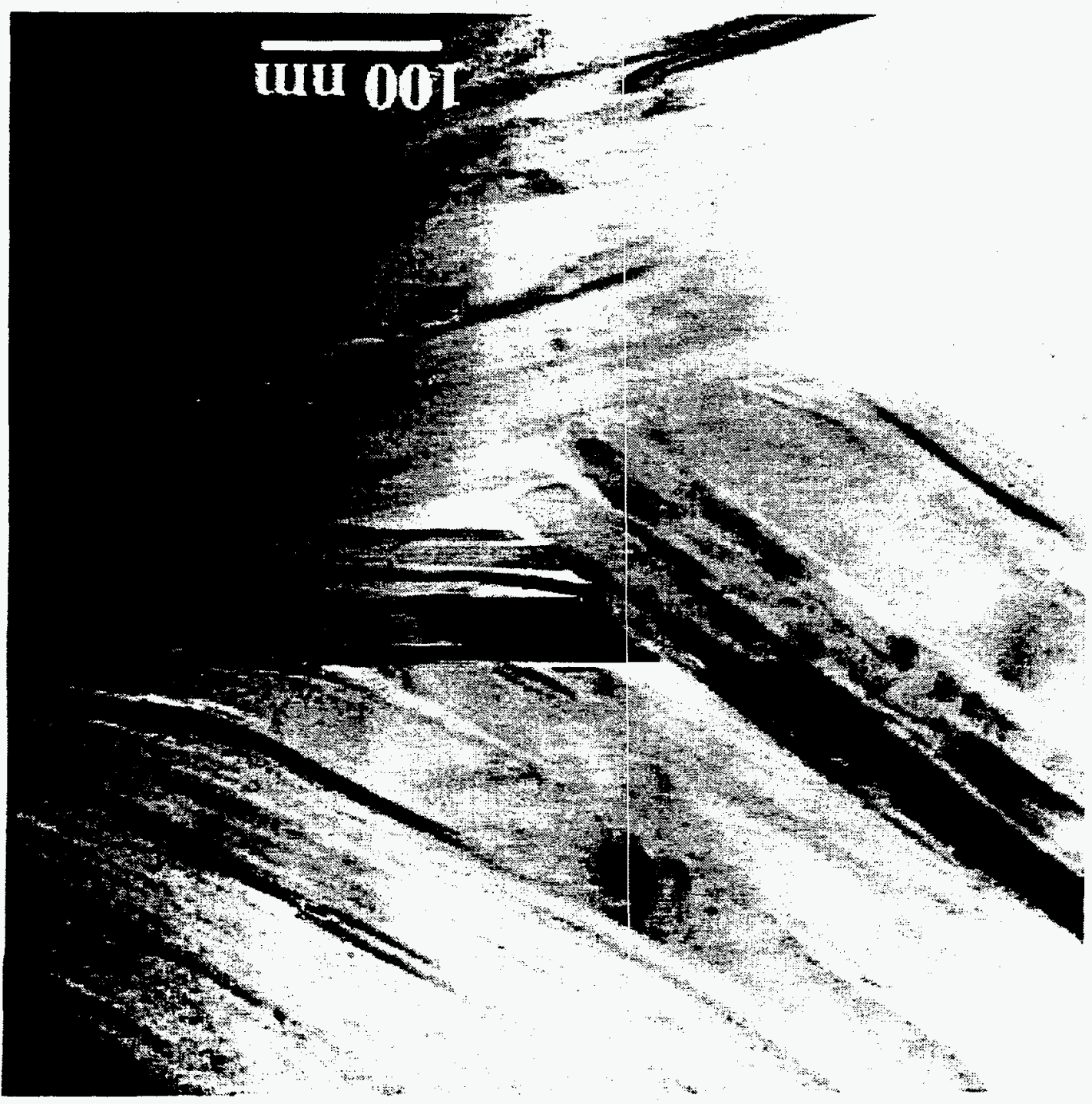




\section{$00 l \quad 20 l \quad 40 t$}

\%

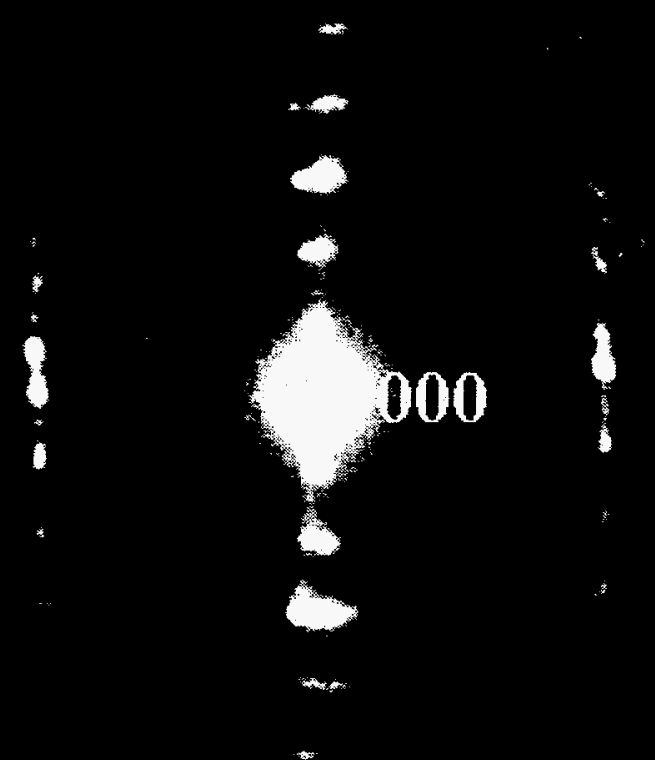

Figure 4-4: $[010]$ zone axis SAED pattern showing weak streaking diffraction along $c^{*}$ direction. Diffraction spots in -201 and 201 diffraction rows indicates there is a 2-layer $\left(2 \mathrm{M}_{2}\right)$ illite polytype. 


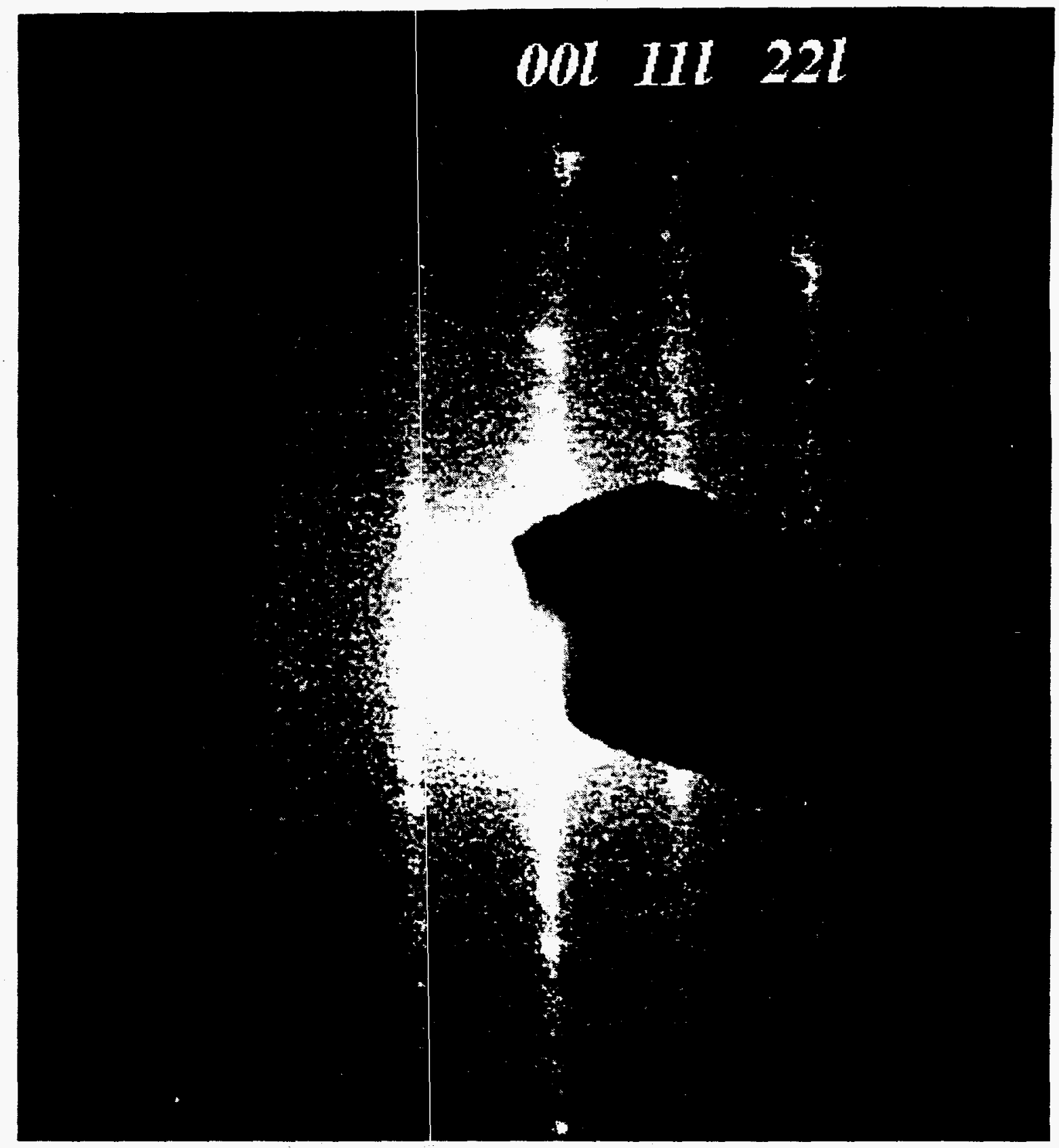

Figure 4-5: $[-110]$ zone axis SAED pattern showing strong streaking diffraction along $c^{*}$ direction. This diffraction pattern indicates highly stacking disorder in the illite/smectite mixed-layer crystal. 


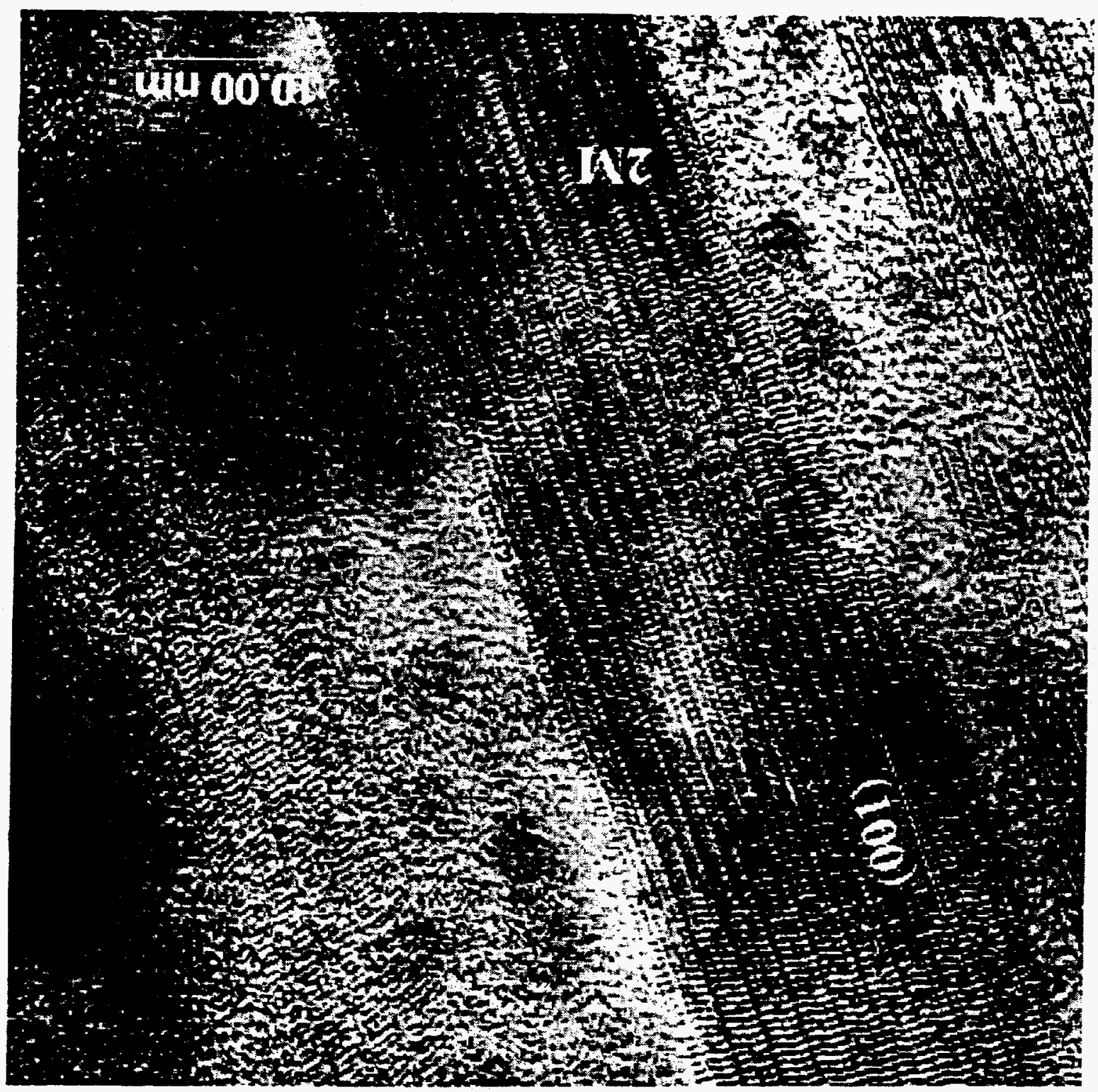




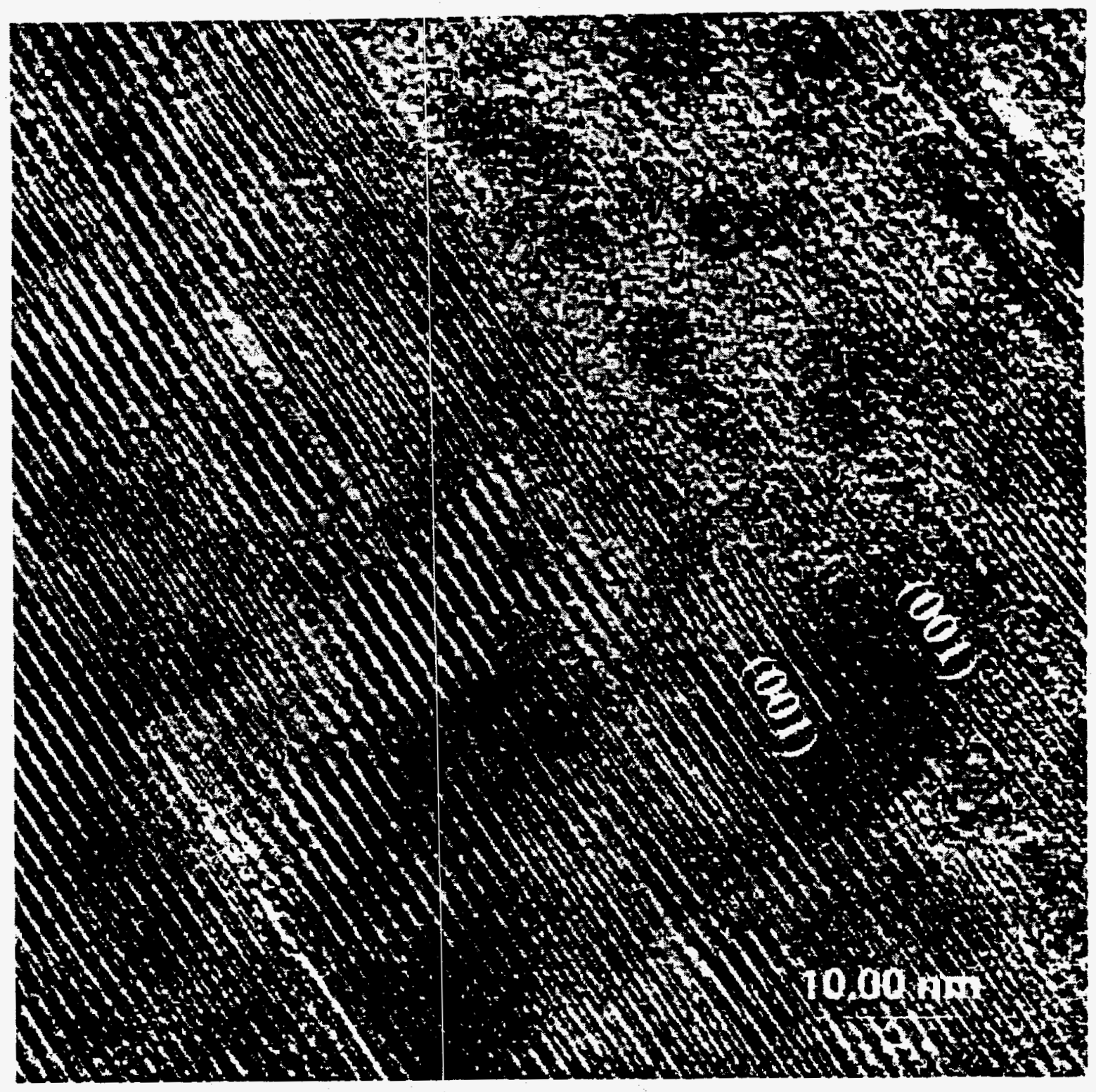

Figure 4-7: HRTEM image showing low angle boundary between neighboring illite crystals. 


\section{LITERATURE CITED}

Buseck, P. R., and Veblen, D. R. (1988) Mineralogy. In P. R. Buseck, J. M. Cowley, and L. Eyring eds. "High-resolution transmission electron microscopy and associated techniques," Oxford, New York, 308-377.

Groffman, A., Crossey, L.J., Sterling, J., and Baker, M., 1996. Redox Cycling Dynamics of Iron and Manganese in a Shallow Alluvial Aquifer. Geological Society of America Abstracts with Programs, v. 28.

Spence, J. C. H. (1988) Techniques closely related to high-resolution electron microscopy. In High-Resolution Transmission Electron Microscopy and Associated Techniques, P. R. Buseck, J. M. Cowley, and L. Eyring, eds., Oxford University Press, New York, 190-243.

Veblen, D. R. (1993) Electron microscopy applied to nanostoichiometry, polysomatism, and replacement reactions in minerals. In P. R. Buseck ed. "Minerals and reactions at the atomic scale: transmission electron microscopy." Mineralogical Society of America, Washington, D. C., 181-230.

Voight, J., Wood, T., Bunker, B., Casey, W., and Crossey, L., eds. (1997) Aqueous Chemistry and Geochemistry of Oxides, Oxyhydroxides, and Related Materials, Materials Research Society, vol. 432 from the MRS Proceedings Series.

Wenk, H. R. (1976) Electron microscopy in mineralogy. Springer-Verlag, Berlin, 564p.

$\mathrm{Xu}, \mathrm{H}$., and Garvie, L. A. J. (1997) Characterization of oxidation states of $\mathrm{Fe}$ in pyroxene and amphibole minerals: transmission electron microscopy and electron energyloss spectroscopy studies. Abstracts with Programs of Geological Society of America Annual Meeting, Salt Lake City, 400-401.

$\mathrm{Xu}, \mathrm{H}$., Buseck, P. R., and Luo, G. (1998) HRTEM investigation of microstructures in a length-slow chalcedony. Am. Mineral., 83 (in press).

$\mathrm{Xu}, \mathrm{H}$., and Veblen, D. R. (1996a) Interstratification and other reaction microstructures in the chlorite-berthierine series. Contribution to Mineralogy and Petrology, 124, 291-301.

$\mathrm{Xu}, \mathrm{H}$., and Veblen, D. R. (1996b) Superstructures and domain structures in natural and synthetic kalsilite. American mineralogist, 81, 1360-1370. 
Table 1. Results of smectite from sample UE-18T/2002' normalized to 11 oxygen atoms

\begin{tabular}{|cllllllll|}
\hline Analysis No. & $\mathrm{Na}$ & $\mathrm{K}$ & $\mathrm{Ca}$ & $\mathrm{Mg}$ & $\mathrm{Fe}$ & $\mathrm{Al}^{\mathrm{VI}}$ & $\mathrm{Al}^{\mathrm{IV}}$ & $\mathrm{Si}$ \\
1 & 0.26 & 0.03 & 0.14 & 0.23 & 0.08 & 1.71 & 0.33 & 3.67 \\
2 & 0.31 & 0.02 & 0.17 & 0.19 & 0.09 & 1.67 & 0.25 & 3.75 \\
3 & 0.08 & 0.01 & 0.10 & 0.12 & 0.03 & 2.06 & 0.76 & 3.24 \\
4 & 0.19 & $-\cdots$ & 0.18 & 0.17 & 0.06 & 1.82 & 0.46 & 3.54 \\
5 & -- & --- & 0.11 & 0.09 & 0.03 & 2.15 & 0.91 & 3.09 \\
\hline
\end{tabular}

$\mathrm{Fe}$ is assumed to be in form of ferrous $\mathrm{Fe}^{2+}$.

Table 2. Results of illite/smectite from sample UE-20F/8668' normalized to 11 oxygen atoms

\begin{tabular}{|clllllllll|}
\hline Analysis No. & $\mathrm{Na}$ & $\mathrm{K}$ & $\mathrm{Ca}$ & $\mathrm{Mg}$ & $\mathrm{Fe}$ & $\mathrm{Al}^{\mathrm{V}}$ & $\mathrm{Al}^{\mathrm{IV}}$ & $\mathrm{Si}$ & Note \\
1 & 0.09 & 0.17 & 0.06 & 0.11 & 0.31 & 1.65 & 0.18 & 3.82 & Smectite \\
2 & 0.12 & 0.84 & 0.08 & 0.10 & 0.58 & 1.41 & 0.72 & 3.28 & $\mathrm{I} / \mathrm{S}$ \\
3 & 0.15 & 0.56 & 0.09 & 0.06 & 0.64 & 1.49 & 0.74 & 3.26 & $\mathrm{I} / \mathrm{S}$ \\
4 & --- & 0.39 & 0.01 & 0.01 & 0.40 & 1.66 & 0.18 & 3.82 & $\mathrm{I} / \mathrm{S}$ \\
\hline
\end{tabular}

$\mathrm{Fe}$ is assumed to be in form of ferrous $\mathrm{Fe}^{2+}$.

Table 3a. Results of illite from sample UE-20F/13674' normalized to 11 oxygen atoms

\begin{tabular}{|clllllllll|}
\hline Analysis No. & $\mathrm{Na}$ & $\mathrm{K}$ & $\mathrm{Ca}$ & $\mathrm{Mg}$ & $\mathrm{Fe}$ & $\mathrm{Mn}$ & $\mathrm{Al}^{\mathrm{VI}}$ & $\mathrm{Al}^{\mathrm{IV}}$ & $\mathrm{Si}$ \\
1 & 0.01 & 0.48 & 0.03 & 0.16 & 0.14 & $\ldots$ & 1.81 & 0.56 & 3.44 \\
\hline
\end{tabular}

$\mathrm{Fe}$ is assumed to be in form of ferrous $\mathrm{Fe}^{2+}$. 
Table $3 \mathrm{~b}$. Results of bertierine from sample UE-20F/13674' normalized to 14 oxygen atoms

\begin{tabular}{|cllllllll|}
\hline Analysis No. & $\mathrm{K}$ & $\mathrm{Ca}$ & $\mathrm{Mg}$ & $\mathrm{Fe}$ & $\mathrm{Mn}$ & $\mathrm{Al}^{\mathrm{V}}$ & $\mathrm{Al}^{\mathrm{IV}}$ & $\mathrm{Si}$ \\
1 & 0.11 & 0.09 & 0.62 & 3.77 & 0.01 & 1.39 & 1.24 & 2.76 \\
2 & --- & --- & 0.53 & 3.87 & --- & 1.35 & 1.36 & 2.64 \\
3 & -- & --- & 0.42 & 3.90 & $\cdots$ & 1.45 & 1.02 & 2.98 \\
4 & --- & --- & 0.30 & 4.54 & -- & 1.18 & 1.19 & 2.81 \\
\hline
\end{tabular}

Fe is assumed to be in form of ferrous $\mathrm{Fe}^{2+}$.

Table 4. Results of illite from sample PM-2/5893' normalized to 11 oxygen atoms

\begin{tabular}{|clllllllll|}
\hline Analysis No. & $\mathrm{Na}$ & $\mathrm{K}$ & $\mathrm{Ca}$ & $\mathrm{Mg}$ & $\mathrm{Fe}$ & $\mathrm{Mn}$ & $\mathrm{Al}^{\mathrm{VI}}$ & $\mathrm{Al}^{\mathrm{IV}}$ & $\mathrm{Si}$ \\
1 & --- & 0.80 & 0.12 & 0.15 & 0.14 & -- & 1.71 & 0.68 & 3.32 \\
2 & --- & 0.80 & 0.12 & 0.13 & 0.15 & -- & 1.70 & 0.69 & 3.31 \\
3 & --- & 0.82 & 0.03 & 0.14 & 0.10 & -- & 1.78 & 0.69 & 3.31 \\
4 & --- & 0.40 & 0.01 & 0.17 & 0.22 & -- & 1.71 & 0.41 & 3.59 \\
5 & --- & 0.87 & 0.03 & 0.38 & 0.17 & $-\cdots$ & 1.61 & 0.81 & 3.19 \\
6 & --- & 0.66 & 0.02 & 0.24 & 0.16 & -- & 1.74 & 0.69 & 3.31 \\
\hline
\end{tabular}

$\mathrm{Fe}$ is assumed to be in form of ferrous $\mathrm{Fe}^{2+}$. 
Appendix 1: X-ray powder diffraction pattern of coating minerals of sample UE18T/2020'

Appendix 2: X-ray powder diffraction pattern of coating minerals of sample UE20F/8668'

Appendix 3: X-ray powder diffraction pattern of coating minerals of sample UE20F/13674'

Appendix 4: X-ray powder diffraction pattern of coating minerals of sample PM2/5893' 
Appendix 1: X-ray powder diffraction pattern of coating layer of sample UE-18T/2020' 


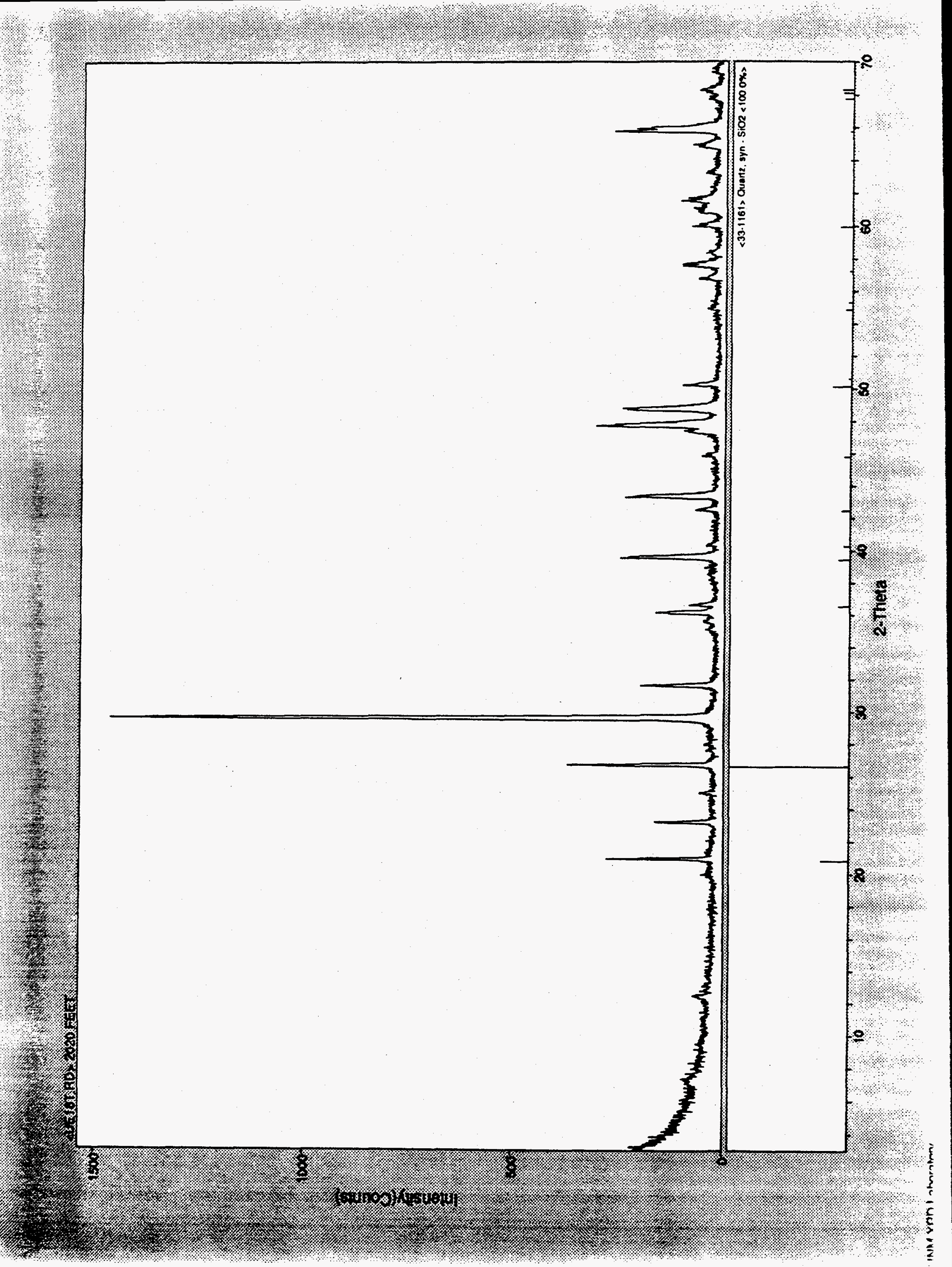




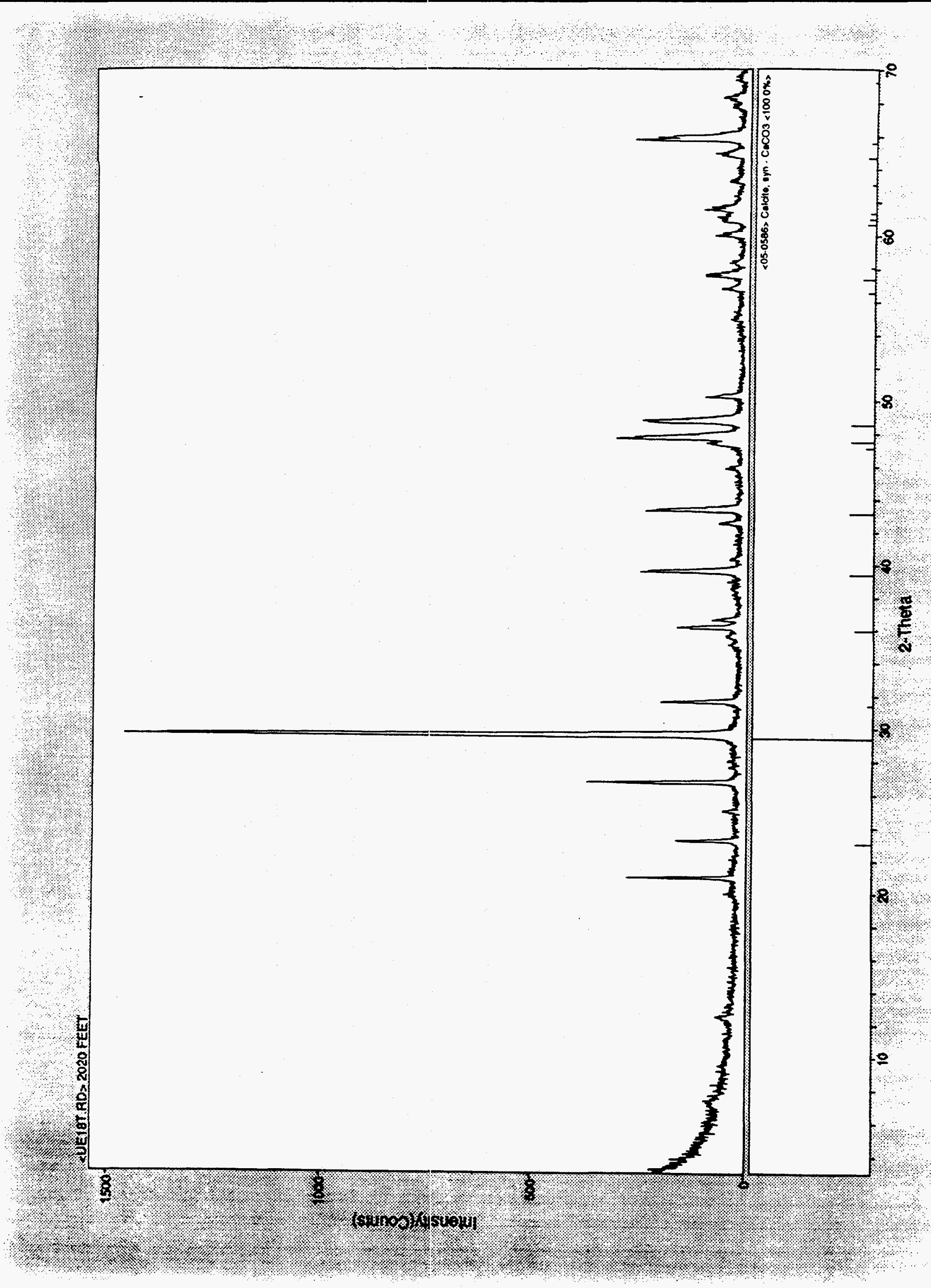


Appendix 2: X-ray powder diffraction pattern of coating layer of sample UE-20F/8668' 


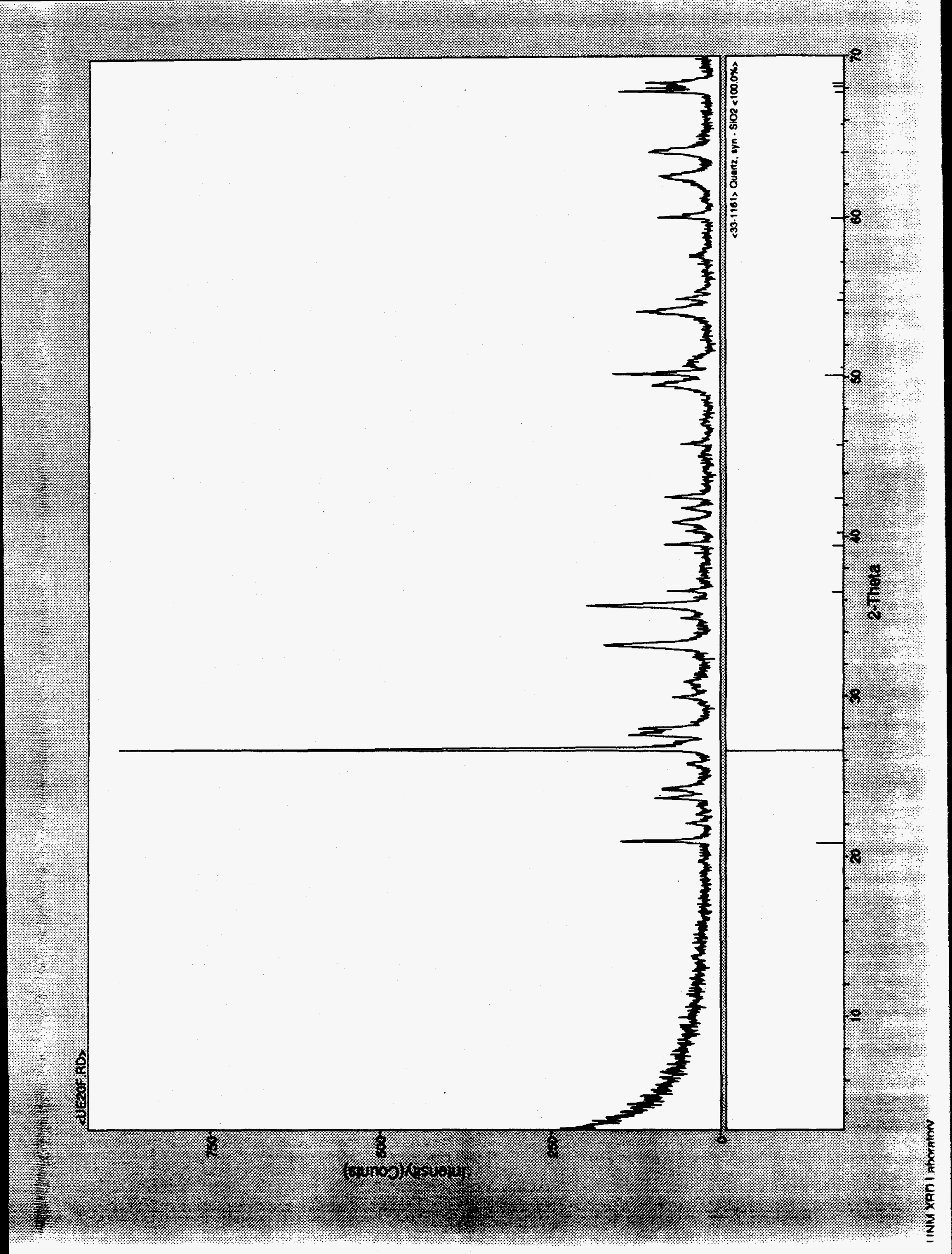




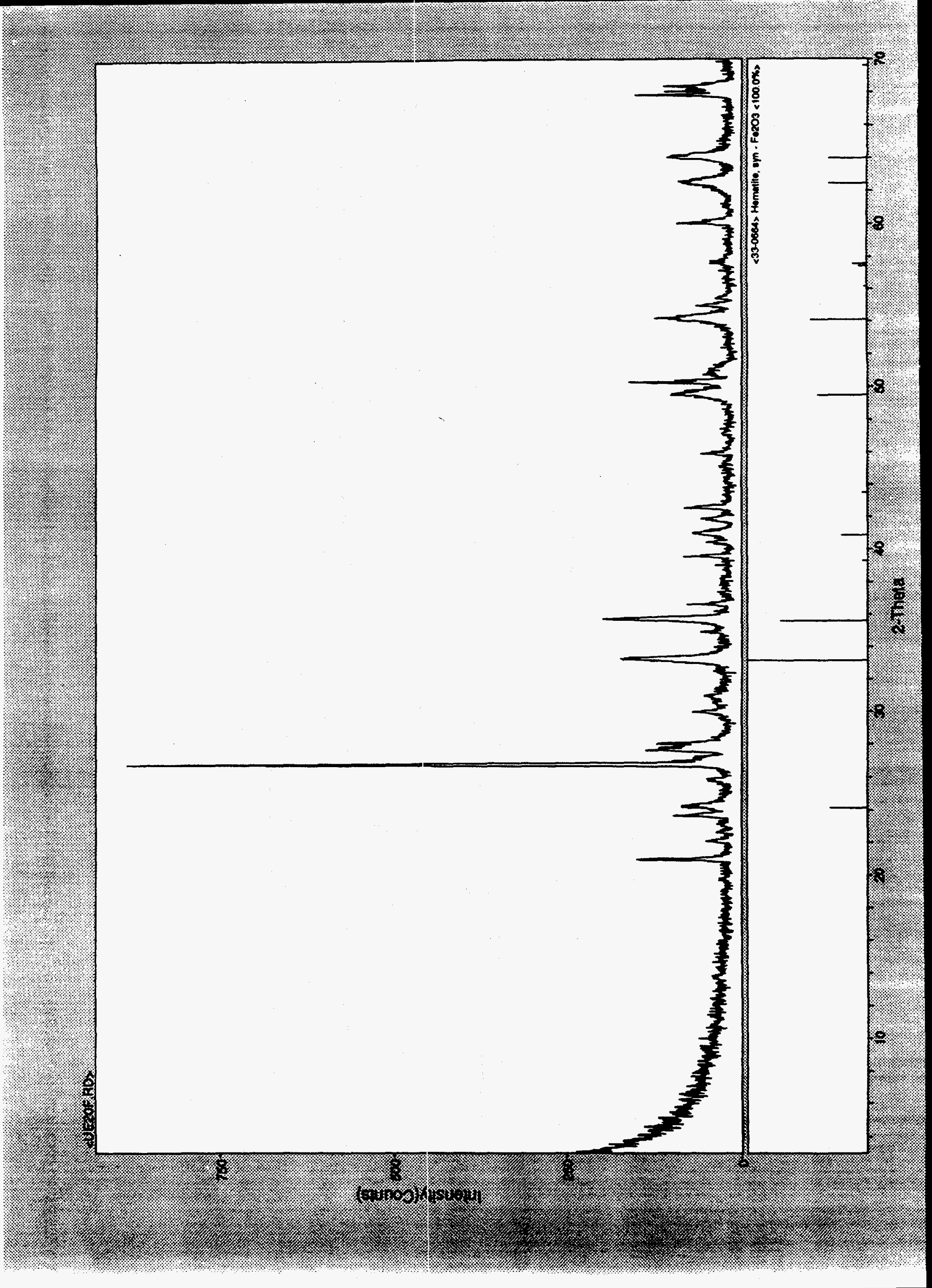




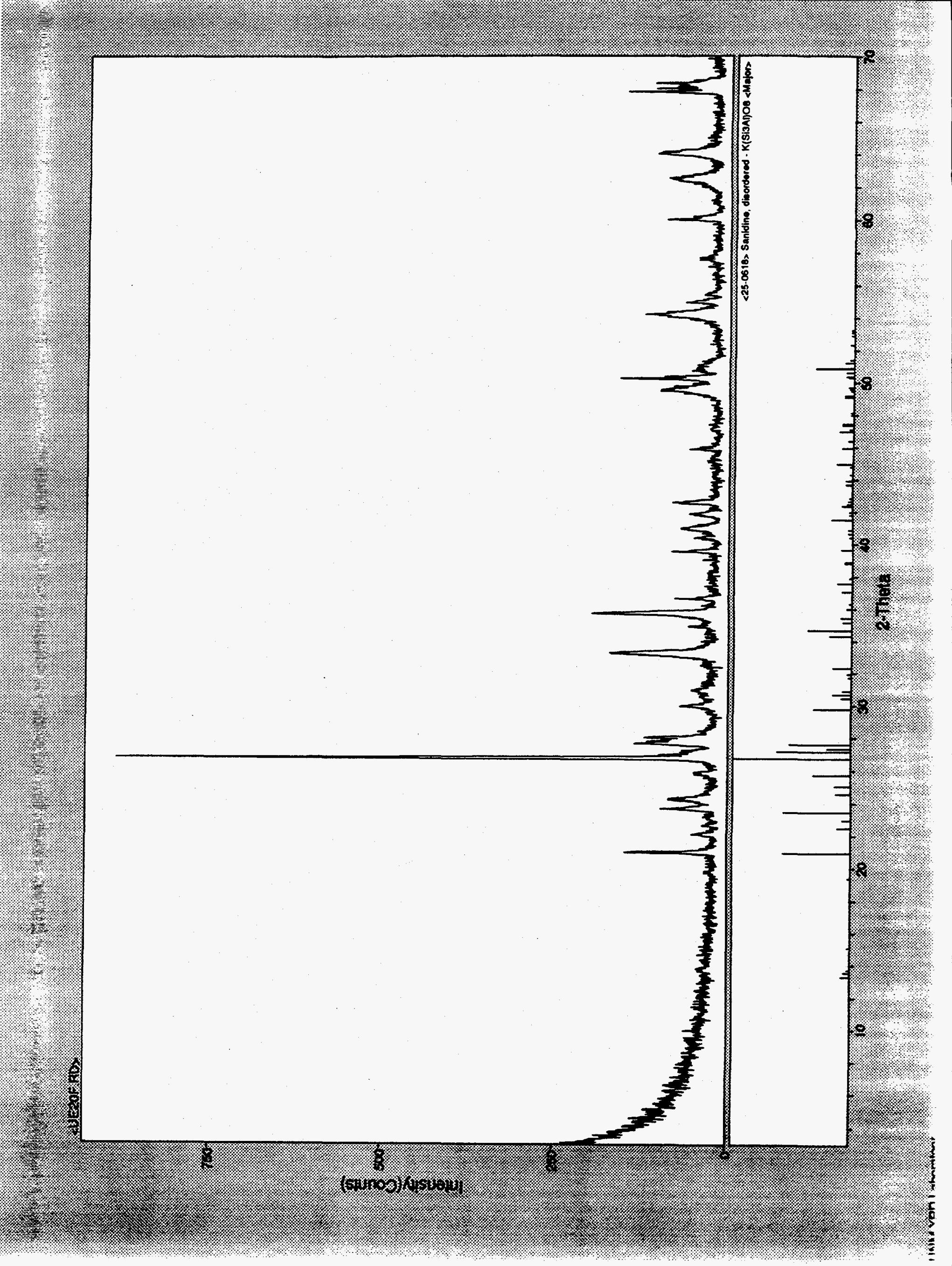




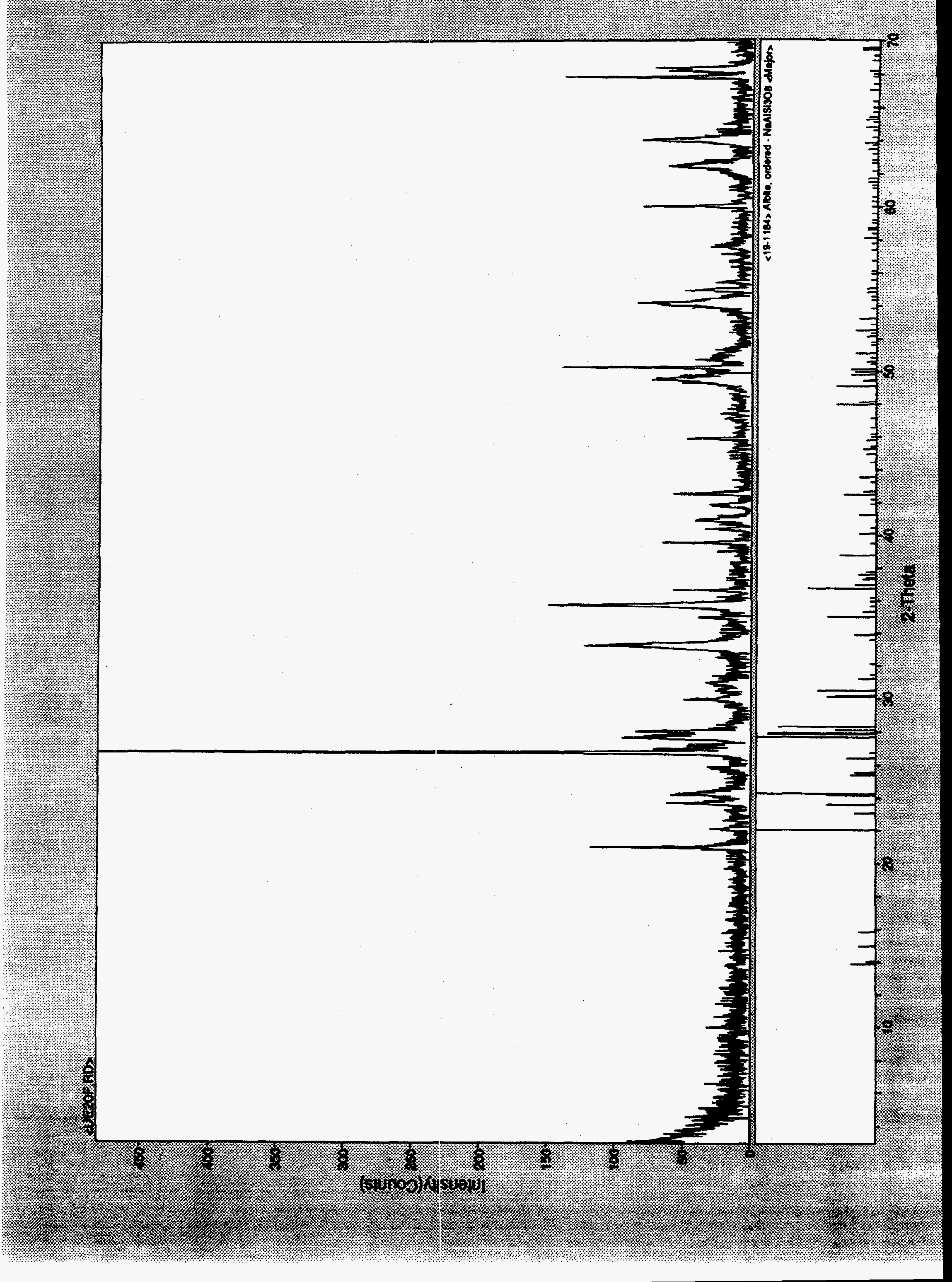


Appendix 3: X-ray powder diffraction pattern of coating layer of sample UE-20F/13674' 


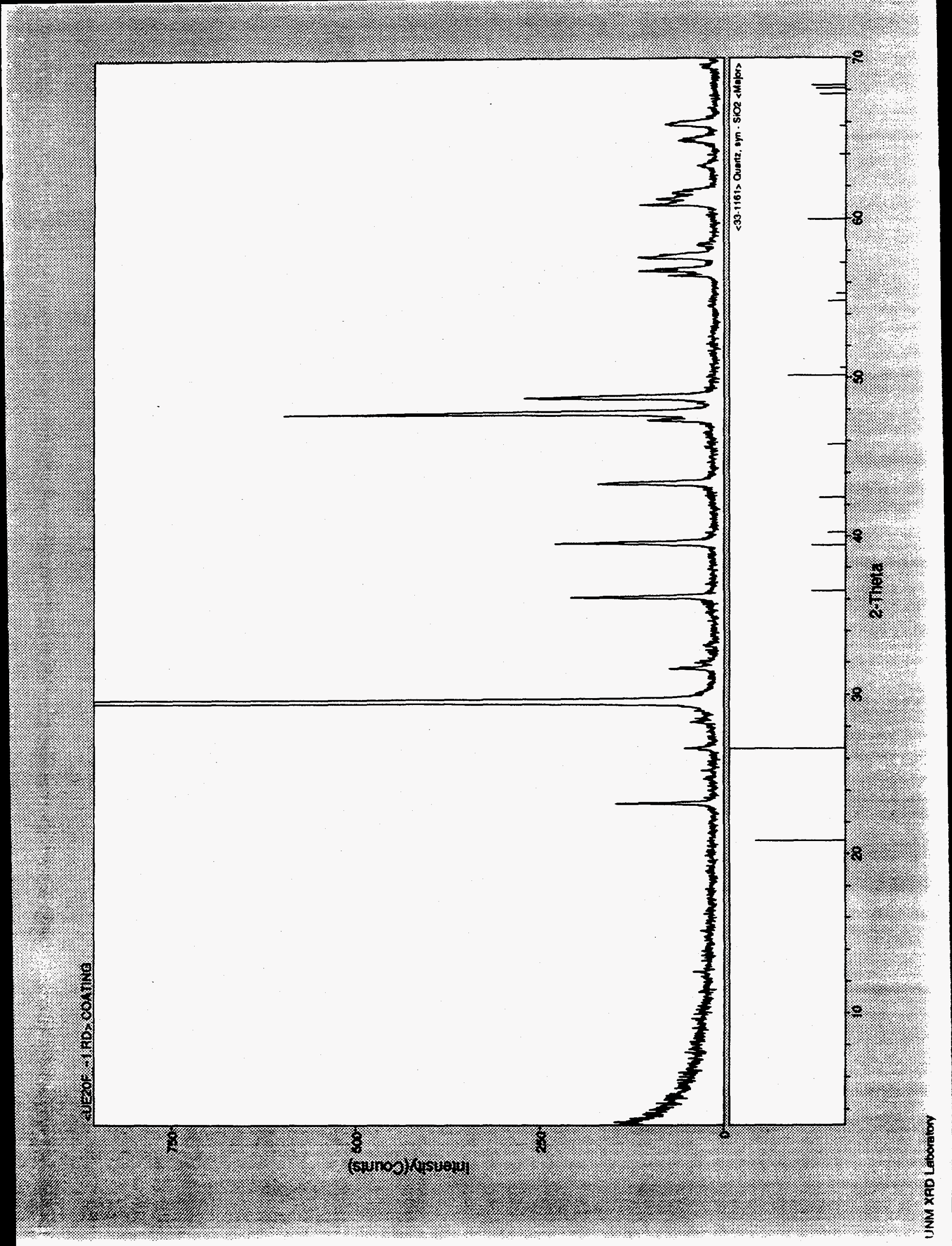




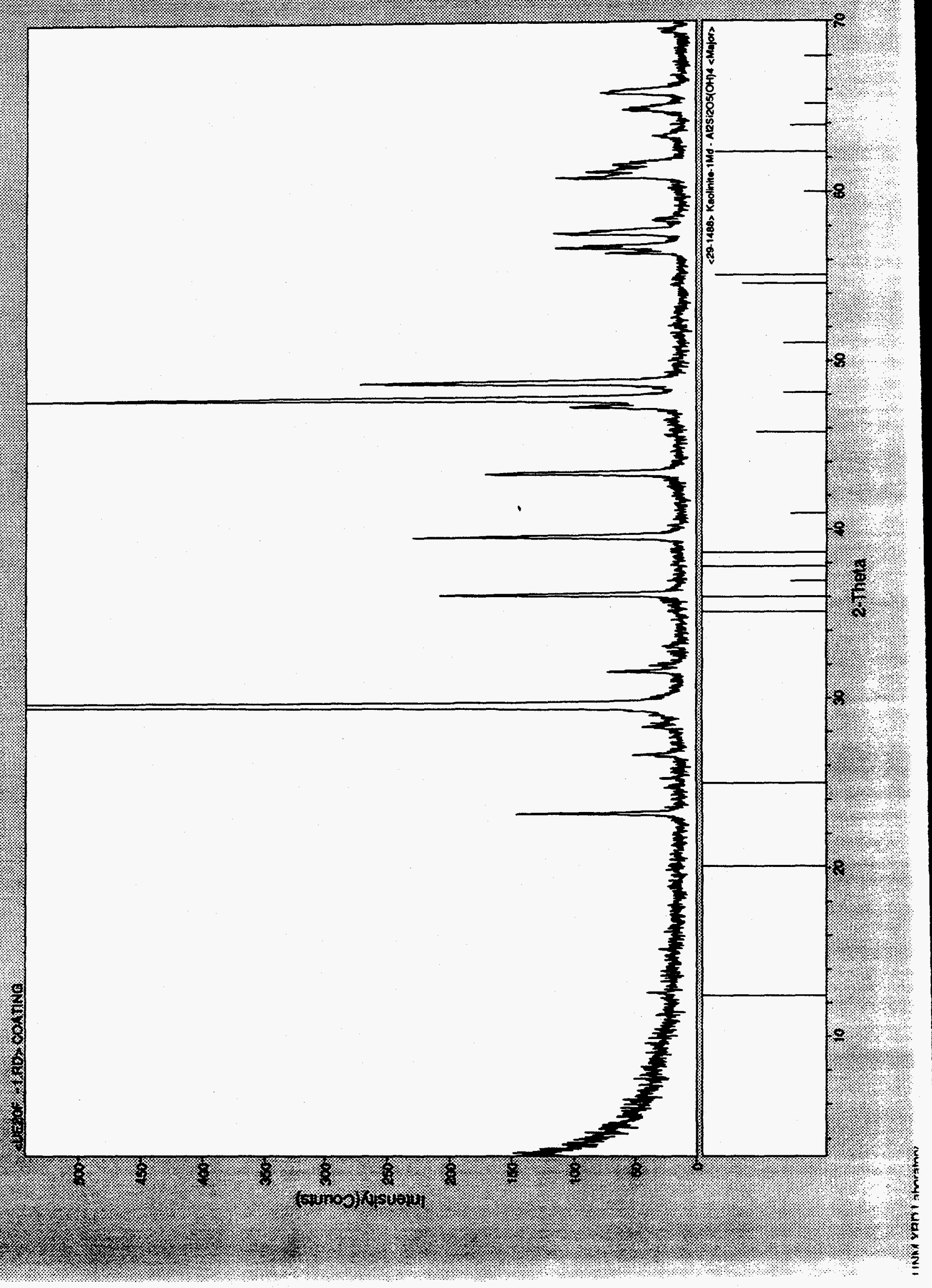


Appendix 4: X-ray powder diffraction pattern of coating layer of sample PM-2/5893' 


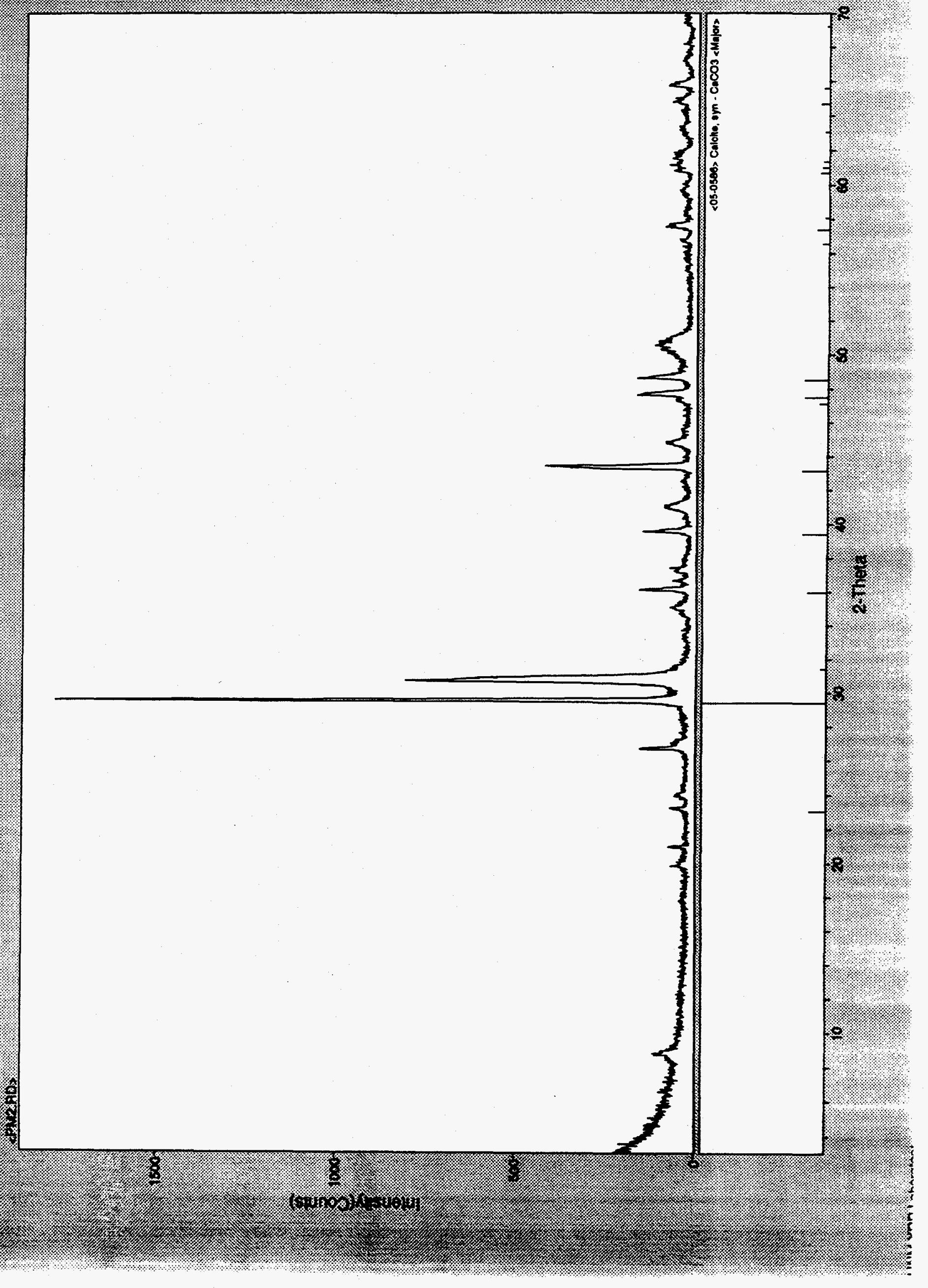




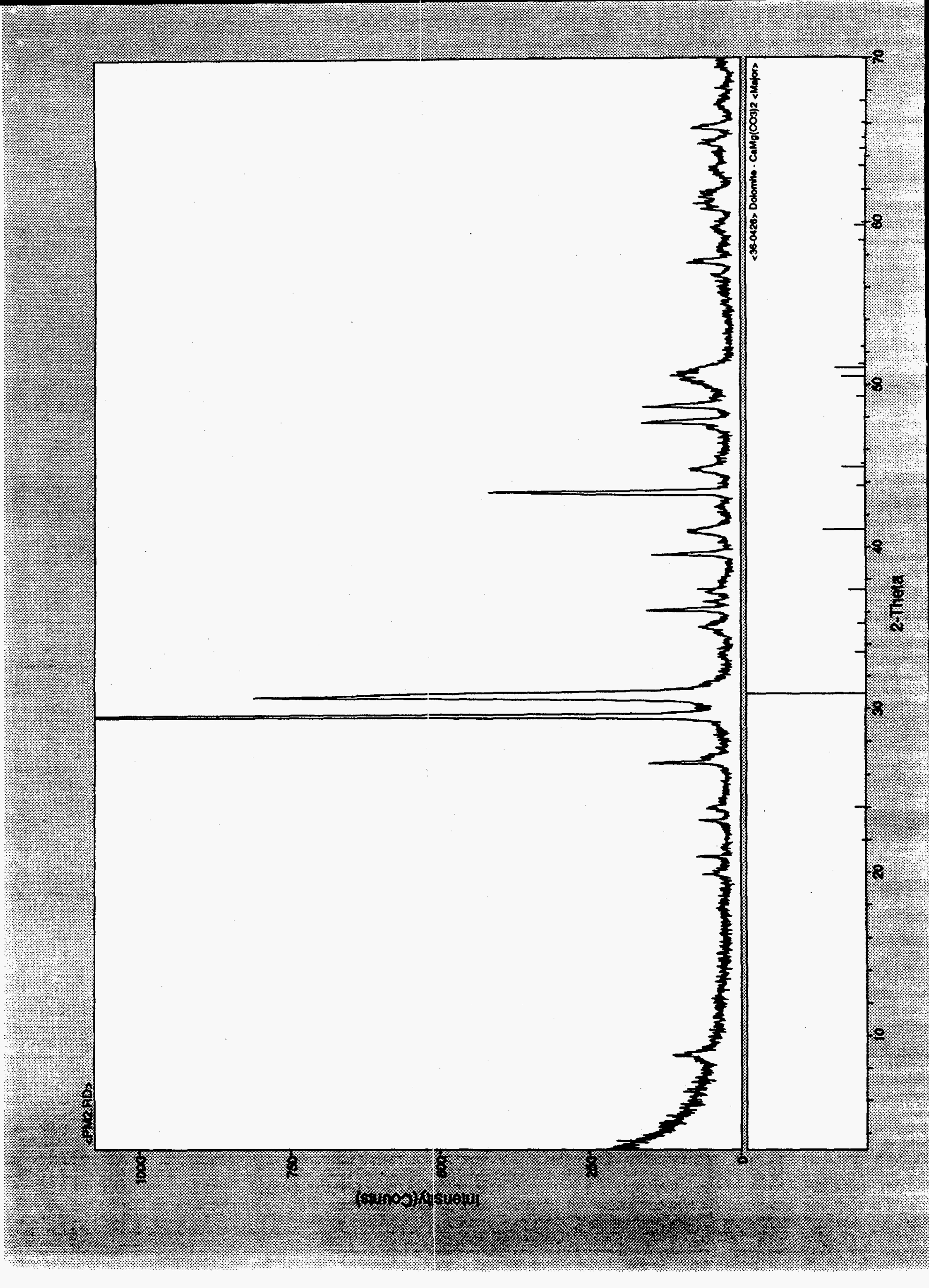




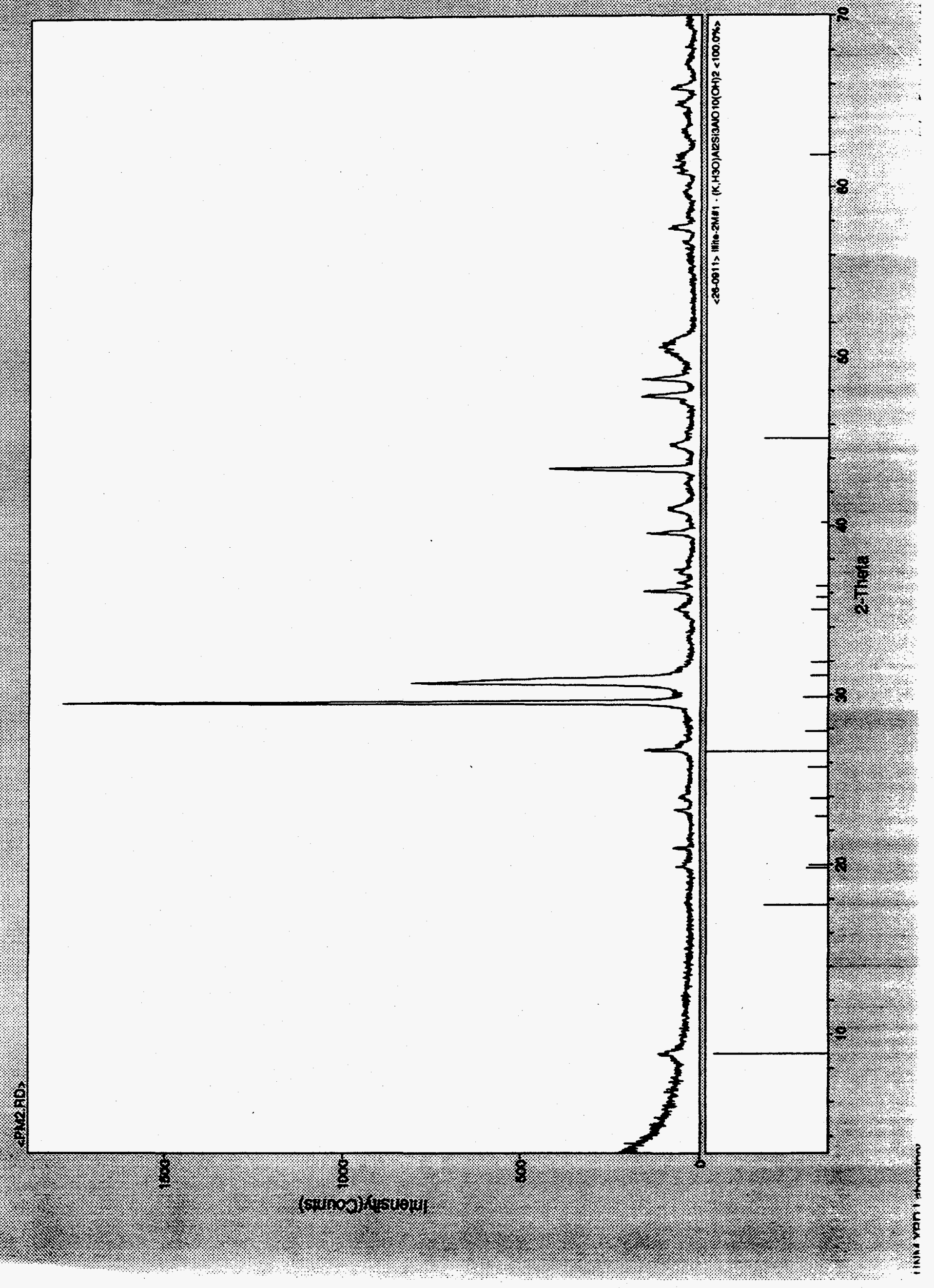




\section{Distribution}

U.S. Department of Energy

Nevada Operations Office

Technical Information Resource Center

P.O. Box 98518

Las Vegas, NV 89193-8518

U.S. Department of Energy

Nevada Operations Office

Public Reading Facility

P.O. Box 98521

Las Vegas, NV 89193-8521

U.S. Department of Energy

Office of Scientific and Technical Information

P.O. Box 62

Oak Ridge, TN 37831-0062

Paul Reimus

CST-7 Chemical Science and Technology

MSJ534

Los Alamos National Laboratory

Los Alamos, NM 87545

Richard Warren

MSD462

Los Alamos National Laboratory

Los Alamos, NM 87545

Richard Waddell

HSI GeoTrans

9101 Harlan, Suite 210

Westminster, CO 80030

Frank Chris Benedict

HSI GeoTrans

50 W. Liberty St., Suite $\mathbf{5 8 0}$

Reno, NV 81501

Robert Bangerter

DOE/Nevada Operations Office

Environmental Restoration Division

P.O. Box 98518, M/S 505

Las Vegas, NV 89193-8518

Janet Wille

IT Corporation

P.O. Box 93838

Las Vegas, Nevada 89030 
Robert Sobocinski

IT Corporation

P.O. Box 93838

Las Vegas, Nevada 89030

Central Files

IT Corporation

P.O. Box 93838

Las Vegas, Nevada 89030

Ron Hershey

Desert Research Institute 7010 Dandini Blvd.

Reno, NV 89512

Jim Thomas

U.S. Geological Survey

Water Resources Division

333 West Nye Lane

Carson City, NV 89706

Timothy Rose

Isotope Sciences Division

Lawrence Livermore National Laboratory

P.O. Box 808, L-231

Livermore, CA 94551

Sig Drellack

Bechtel Nevada

P.O. Box 98521

Las Vegas, NV 89193-8521 